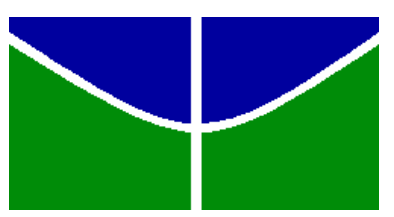

Universidade de Brasília

Instituto de Ciências Humanas

Programa de Pós-Graduação em Filosofia

THIAGO DA SILVA SOARES

CRÍTICA E RECONHECIMENTO

Honneth: a tentativa de reaver o "social" no escopo da tradição da Teoria Crítica

\title{
Brasília
}




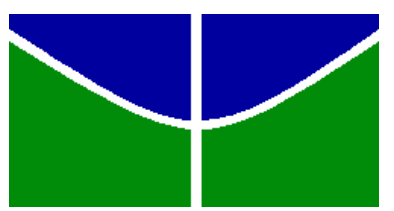

Universidade de Brasília

Instituto de Ciências Humanas

Programa de Pós-Graduação em Filosofia

THIAGO DA SILVA SOARES

\section{CRÍTICA E RECONHECIMENTO}

Honneth: a tentativa de reaver o "social" no escopo da tradição da Teoria Crítica

Dissertação apresentada ao Programa de PósGraduação em Filosofia da Universidade de Brasília como requisito à obtenção do título de Mestre em Filosofia.

Orientador: Prof. Dr. Erick Calheiros Lima

Banca examinadora:

Prof. Dr. Filipe Augusto Barreto Campello de Melo -UFPE/PE

Prof. Dr. Herivelto Pereira de Souza -FIL/UnB

\section{Brasília}


Ficha catalográfica elaborada pela Biblioteca Central da Universidade de Brasília. Acervo 1019356.

Soares, Thiago da Silva.

H773.Ys Crítica e reconhecimento : Honneth : a tentativa de reaver o "social" no escopo da tradição da Teoria Crítica / Thiago da Silva Soares. -- 2014. $125 \mathrm{f}$. ; $30 \mathrm{~cm}$.

Dissertação (mestrado) - Universidade de Brasília, Instituto de Ciências Humanas, Programa de Pós-Graduação em Filosofia, 2014.

Orientação: Erick Calheiros Lima.

Inclui bibliografia.

1. Honneth, Axel, 1949- - Crítica e interpretação.

2. Teoria crítica. 3. Ciências sociais - Filosofia.

4. Reconhecimento (Psicologia). 5. Justiça (Filosofia).

I. Lima, Erick Calheiros de. II. Título. 


\section{AGRADECIMENTOS}

Em primeiro lugar, gostaria de agradecer ao Departamento de Filosofia da UnB pela oportunidade de realizar este Mestrado. À Nádia e Herivelton, secretários da Pós-graduação de Filosofia, por toda a ajuda prestada, pela solução das dúvidas e resolução dos mais variados problemas. Ao professor Miroslav Milovic pelas ótimas discussões que tivemos em seu curso. Aos professores Alexandre Hahn e Herivelto Pereira, pela presença na qualificação do trabalho e pelas valiosas contribuições, além da leitura da primeira versão pública deste texto. Ao professor Filipe Campelo e, mais uma vez, ao professor Herivelto Pereira, por aceitarem o convite de fazer parte da banca examinadora da dissertação, um agradecimento especial. Como também não poderia deixar de agradecer especialmente ao meu orientador: o professor Erick Calheiros Lima, que, em diversos momentos ao longo dos últimos três anos, respondeu pacientemente perguntas, solucionou dúvidas, ajudou no recorte de temas e formulação de perguntas e direcionou com um valor que ninguém poderia avaliar a realização da pesquisa aqui apresentada.

À meus amigos Erick Leão e Felipe Cabral, com quem discuti Honneth e reconhecimento várias vezes, que sabem o quanto foi indispensável tê-los por perto, seja para estudar seja para contar com amigos de verdade. Isto vale também para Roberto, Laís, Wanessa, Antônio, Andressa e Débora. Todos vocês são parte daquele pequeno mundo fora da academia que insiste em despertar emoções ainda maiores do que a teoria.

Por fim, como não poderia deixar de ser, à minha família eu gostaria de oferecer muito mais que estas páginas, pois eles me dão muito mais do que peço. Aos meus tios, primos e ao meu irmão Felipe, que apesar da distância sempre apoiou meus estudos.

Aos meus pais, Maria Divina e João Alves, a dedicatória da dissertação e dos esforços que aqui começam a tomar forma em busca de um mundo em que, um dia, amor, respeito e orgulho que sinto por vocês estejam presentes na forma como todos vemos uns aos outros. 
“A 'reflexão' abandonada a si mesma deixa as totalidades orgânicas desunidas ruírem nas suas partes isoladas. Ela desfaz as relações intersubjetivas transformando-as em consequências da ação, observada reciprocamente, de atores que decidem conforme fins racionais, de tal modo que os indivíduos isolados são cortados das raízes das suas procedências comuns."

Jürgen Habermas 


\section{RESUMO}

O tema da dissertação é a Teoria do Reconhecimento proposta pelo pensador alemão Axel Honneth. De acordo com Honneth, uma Teoria do Reconhecimento seria a forma mais adequada para suprimir os impasses que, segundo ele, perpassam a tradição da Teoria Crítica desde sua fundação, nos 1930, por Max Horkheimer e seus colaboradores no Instituto de Pesquisa Social de Frankfurt (Institut für SocialforschungIfS). A Teoria do Reconhecimento visa, portanto, por um lado superar as aporias a que chegaram as gerações anteriores de teóricos críticos e, por outro lado, cumprir as tarefas fundamentais de uma crítica no sentido proposto por Horkheimer em seus textos: que a teoria esteja ancorada na realidade como parte dela, e, justamente por isso, seja capaz de mostrar quais são os elementos não desenvolvidos do real que permitem perceber os horizontes de sua superação através da crítica. Honneth propõe uma elucidação categorial da realidade social que perpassa a teorização acerca de fontes da experiência que sejam "interiores" às próprias práticas sociais, caracterizadas pela ideia de reconhecimento. Nesse ínterim o presente trabalho pretende elucidar o conceito de "social" que perpassa todo o trabalho de Honneth e o permite fundar uma teoria moderna do reconhecimento e justiça.

Palavras-chave:Teoria Crítica,Teoria do Reconhecimento, Axel Honneth. 


\begin{abstract}
The theme of this work is the theory of the recognition proposed by the German thinker Axel Honneth. According to Honneth a Theory of Recognition would be the most appropriate way to suppress the impasses that, he said, pervade the tradition of Critical Theory since its founding in 1930 by Max Horkheimer and his collaborators at the Institute for Social Research in Frankfurt (Institut für Socialforschung-IfS). The Theory of Recognition is therefore intended, first overcome the aporias reached by previous generations of critical theorists, and the other to achieve the fundamental tasks of a critical in the sense proposed by Horkheimer in his writings: that the theory is anchored in reality as part of it, and rightly so, to be able to show what the undeveloped elements of real that allows to perceive the horizons of its overcoming through the critical. Honneth proposes a categorical elucidation of social reality that permeates theorizing about sources of experience that are "internal" to their own social practices, characterized by the idea of recognition. Meanwhile this study aims to elucidate the concept of "social" running through the whole work of Honneth and enables you found a modern theory of recognition and justice.
\end{abstract}

Keywords: Critical Theory, Theory of Recognition, Axel Honneth. 

INTRODUÇÃ $O$................................................................................................................................................. 10

PARTE I: DÉFICT SOCIOLÓGICO DA TEORIA CRÍTICA ................................................. 17

1. A IDÉIA ORIGINAL DE HORKHEIMER E APORIAS DE UMA FILOSOFIA DA HISTÓRIA ..................... 17

2. DIALÉTICA DO ESCLARECIMENTO: FILOSOFIA DA HISTÓRIA COMO DOMINAÇÃO ....................... 27

3. FOUCAULT: DISSOLUÇÃO TEÓRICO-SISTÊMICA DA DIALÉTICA DO ESCLARECIMENTO 36

4. HABERMAS: A "VIRADA COMUNICATIVA" E A FICÇÃO DE UMA SOCIEDADE DIVIDIDA

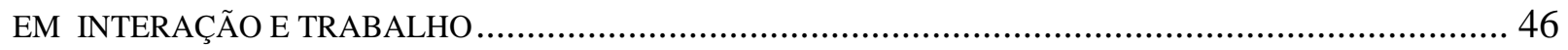

PARTE II: TEORIA DO RECONHECIMENTO....................................................................... 56

1.A RETOMADA DO "SOCIAL" A PARTIR DE UMA TEORIA DO RECONHECIMENTO .......................... 56

2. RECONHECIMENTO E DESRRESPEITO: ESTRUTURA DAS RELAÇÕES SOCIAIS DO

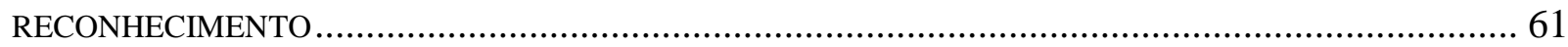

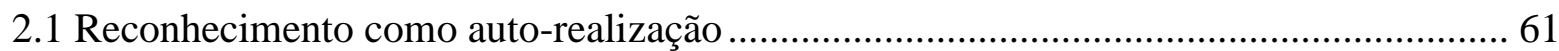

2.2 Desrespeito como Patologia - Ameaça a Integridade ................................................... 72

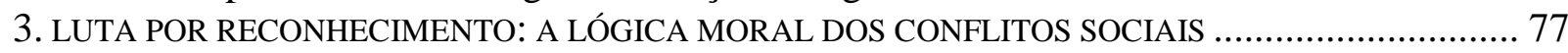

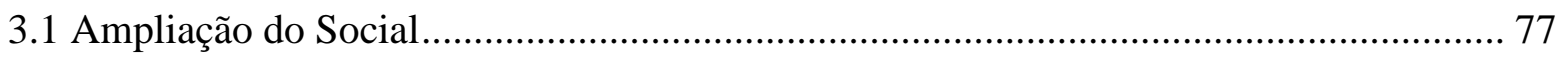

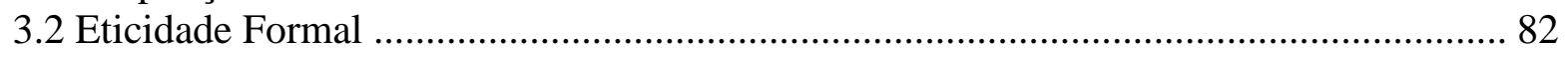

PARTE III: TEORIA DA JUSTIÇA COMO ETICIDADE..................................................... 89

4. JUSTIÇA COMO ETICIDADE ………………………………………………….... 89

4.1 Filosofia do Direito como Teoria da Justiça....................................................................... 89

4.2 Patologias do Social e Função "Terapêutica" da Eticidade .............................................. 96

4.3 Doutrina da Eticidade como Teoria Normativa da Modernidade................................... 101

4.4 Crítica à "Superinstitucionalização da Eticidade em Hegel" .......................................... 103

CONSIDERAÇÕES FINAIS............................................................................................................ 113

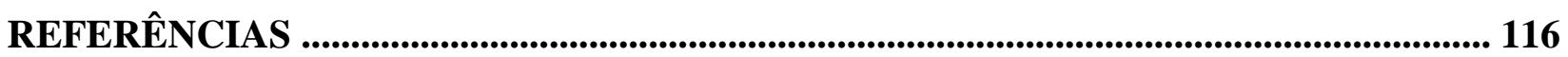




\section{INTRODUÇÃO}

Esta dissertação tem como tema a Teoria do Reconhecimento proposta pelo pensador alemão Axel Honneth. De acordo com Honneth, uma Teoria do Reconhecimento seria a forma mais adequada para suprimir os impasses que, segundo ele, perpassam a tradição da Teoria Crítica desde sua fundação, nos 1930, por Max Horkheimer e seus colaboradores no Instituto de Pesquisa Social de Frankfurt (Institut für Socialforschung-IfS) ${ }^{1}$. A Teoria do Reconhecimento visa, portanto, por um lado superar as aporias a que chegaram as gerações anteriores de teóricos críticos e, por outro lado, cumprir as tarefas fundamentais de uma crítica no sentido proposto por Horkheimer em seus textos: que a teoria esteja ancorada na realidade como parte dela, e, justamente por isso, seja capaz de mostrar quais são os elementos não desenvolvidos do real que permitem perceber os horizontes de sua superação através da crítica ${ }^{2}$. Em "Uma Patologia Social da Razão: Sobre o Legado Intelectual da Teoria Crítica”, Axel Honneth, ao tratar sobre a necessidade de atualização das ideias histórico-filosóficas da Teoria Crítica, afirma que esta em suas diversas formulações é devedora da ideia ética hegeliana de um universal racional, isto é, da ideia de que uma sociedade bem sucedida deve permitir que seus integrantes percebam o potencial racional já "objetivamente" inscrito nas instituições "éticas" universais do corpo social. Em todas as abordagens da Teoria Crítica, "a mesma ideia hegeliana - que um universal racional é sempre requerido para a possibilidade da completa auto-realização efetiva no interior da sociedade- é continuamente incorporada, ainda que em diferentes caracterizações da originária práxis humana da ação"4. As patologias do social são entendidas como resultado da inabilidade da sociedade para expressar apropriadamente o potencial racional já inerente em suas instituições, práticas e rotinas cotidianas. Segundo Honneth, é essa ideia que permite aos teóricos críticos analisarem a realidade social a partir de uma teoria da racionalidade enquanto patologia social da razão ${ }^{5}$. Daí decorre a centralidade da ideia hegeliana de formação histórica da razão. O processo histórico de deformação da razão deve ser explicado com vista a converter a ideia normativa de uma

\footnotetext{
1 A ideia de uma Teoria Crítica da sociedade, porém, não é originalmente criada por Horkheimer, mas sim por toda a tradição que remonta à crítica de Karl Marx à economia política, que passa por Friedrich Engels e Georg Lukács antes de consolidar-se, já como uma corrente específica dentro da teoria da sociologia, e mesmo do marxismo, em Frankfurt, no começo da década de 1930. Sobre as relações entre marxismo e Teoria Crítica, ver Assoum e Raulet, 1981.

${ }^{2}$ Horkheimer, 1968a

${ }^{3}$ Honneth, 2008.

${ }^{4}$ Cf. Honneth, 2008, p.395.

${ }^{5}$ Cf. Honneth, 2008, p.393.
} 
racionalidade social bem sucedida em prática social concreta. No entanto, como afirma Honneth, esse processo não pode mais ser explicado à luz do conceito idealista da razão hegeliano, a explicação sociológica do processo de deformação da razão constitui outro traço marcante da tradição crítica. A ideia Hegeliana de formação histórica da razão deve ser interpretada como processo conflituoso e multifacetado de aprendizagem na qual os sujeitos respondem a todo o momento aos desafios objetivos colocados, tanto pela natureza quanto pela organização social, ao aperfeiçoarem constantemente seu conhecimento da ação ${ }^{6}$.

Para Honneth, no entanto, a explicação sociológica da noção hegeliana da realização da razão ao longo da tradição da teoria crítica permaneceu insuficiente. Esta ideia é desenvolvida no seu livro Crítica do Poder $^{7}$ (Kritik der Macht: Reflexionsstufen einer kritischen Gesellschaftstheorie). Para Honneth toda tradição crítica sofre de um "déficit sociológico", que segundo ele, desdobra-se num esvaziamento do potencial prático crítico da Teoria Crítica. Por meio de um processo que vai de Horkheimer e Adorno, através de Foucault, até Habermas, ele busca apresentar os estágios reflexivos em que se trabalham as premissas conceituais a uma teoria crítica que pretenda explicar as estruturas de dominação contemporâneas ao mesmo tempo em que, apontando as limitações destes autores, pretende que a prática social apareça de um modo mais claro na crítica da dominação, com a fundamentação de um modelo de teoria social em que a sociedade seja entendida em seu nível fundamental como um espaço de conflito. Daí a inclusão de Foucault (que não é um teórico crítico no sentido definido por Horkheimer) num estudo sobre os estágios reflexivos da Teoria Crítica.

A crítica feita por Honneth, em relação ao que chama de "déficit sociológico" da Teoria Crítica, se baseia na premissa de que seus estudos foram determinados por uma filosofia da história que reduz o processo histórico a uma dimensão de dominação sobre a natureza, ou seja, reduzem toda a ação social naquilo que Marx chamava de reificação - a coisificação do cotidiano mediado pelo sistema de produção. Embora o modo específico como Horkheimer entrelaçou teoria e prática, baseado em Marx, pressuponha a análise, de dentro dos processos históricos dos conflitos sociais(impulsos sociais), este não poderia resolver suas próprias questões quanto à filosofia da História por estar demais preso à dimensão do trabalho, ao passo que Adorno levou este ponto ainda mais adiante ao ver na ação social (ainda sob a perspectiva do trabalho como ação

\footnotetext{
${ }^{6}$ Cf. Honneth, 2008, p.403.

${ }^{7}$ Utilizaremos a versão traduzida para o inglês, cujo título é The Critique of Power: reflective stages in a critical social theory, traduzida por Kenneth Baynes, publicada em 1991 pela MIT Press.
} 
fundamental do processo de humanização) uma mera extensão da dominação humana sobre a natureza. Foucault e Habermas aprofundam o tratamento do domínio do social, no entanto, embora tenham avançado sobre as aporias a que chegaram Horkheimer e Adorno, ambos se depararam com limitações de suas próprias teorias com relação ao modelo definido por Horkheimer como crítico.

Para Foucault o social é entendido como uma esfera que se constrói por meio da interação estratégica entre atores que estão em batalha constante pelo estabelecimento de seus interesses. Mesmo tendo aberto o campo de análise das esferas sociais de interação e dos conflitos sociais, Foucault não delineou produtivamente bases normativas nem morais, em sua teoria do poder, tornando-a simplesmente uma explanação teórico-sistêmica dos processos sociais. Finalmente, Habermas com seu conceito de ação comunicativa, cria uma estrutura em que a dominação pode ser explicada como resultado de um processo comunicativo danificado. Contudo, ele trabalha com duas teorias sociais diferentes ao longo de sua obra, sendo que na primeira, o problema da dominação é tratado como uma dinâmica do conflito social estruturalmente localizado no espaço moral da interação social, enquanto na segunda a lógica da racionalização ocupa o lugar da disputa moral por meio da ideia de uma sobreposição da racionalidade finalista à racionalidade comunicativa. $\mathrm{O}$ fato de ele ter aprofundado apenas este segundo modelo sugere a Honneth que ao invés de uma teoria do conflito social Habermas desenvolve uma teoria em que o conflito ocorre entre dois tipos de lógica racional entendidos de maneira reificada e não como uma teoria efetivamente voltada para a análise da integração social. O resultado disto, em sua visão, é que Habermas acaba por transformar a teoria da ação comunicativa em uma teoria sobre lógicas de interação e não em uma teoria social. Em sua opinião, porém, o modelo de Habermas é aquele cujos avanços são os mais significativos, pois é o único que apresenta a ideia de uma lógica capaz de confrontar aquela racionalidade totalitária teorizada por Adorno e Horkheimer. Apesar disto, este modelo ainda é um tanto quanto abstrato e mecanicista, na visão de Honneth, uma vez que não percebe as dimensões conflitivas internas às próprias relações de interesse. Com isso, Habermas seria capaz de apresentar uma proposta concreta de oposição à dominação técnica, mas não um sujeito empírico que pudesse realizar por meio da experiência a tarefa de uma integração emancipatória. 
Ao identificar uma incapacidade da Teoria Crítica de uma analítica social e criticar Habermas pela sua escolha, Honneth começa já neste livro, a esboçar qual seria sua própria visão sobre a Teoria Crítica atualmente. Mas somente em "Luta por Reconhecimento: A Gramática Moral dos Conflitos Sociais" ${ }^{\prime 8}$, que ele desenvolve seu modelo crítico, a Teoria do Reconhecimento. Honneth visa “[...] elucidar categorialmente a realidade social", situando o conflito social e os sentimentos de desrespeito e injustiça no centro da Teoria Crítica. Para tanto lança mão das intuições do jovem Hegel e passa a interpretar os conflitos entre os sujeitos como uma luta por reconhecimento. Desse modo, ele compreende as esferas sociais do reconhecimento como algo que compõe os fundamentos da realidade social a partir de onde é possível extrair critérios para uma teoria moderna do reconhecimento e justiça. O seu modelo prevê uma tipologia tripartite de reconhecimento formada por três tipos básicos de relações sociais que, quando garantidas ao indivíduo propiciam um processo bem sucedido de formação, isto porque as formas por ele identificadas, o amor(relação afetiva), os direitos(relação jurídica) e a estima social( relação de solidariedade), cobrem as áreas de formação de três auto-relações básicas do sujeito para a participação ativa na vida social: a auto-confiança, o auto-respeito e a auto-estima, respectivamente. No entanto, retomando seu foco em buscar experiências de injustiça que motivem os conflitos sociais, ele procura também estabelecer uma tipologia do desrespeito, contraposta a esta primeira, na qual as formas de violência e incapacidade de dispor da própria autonomia, privação de direitos e degradação social são vistas como formas de ação social que agridem aquelas relações positivas de reconhecimento e, por isso, impedem a formação bem sucedida da personalidade. Uma vez estabelecida uma relação entre reconhecimento e desrespeito na esfera moral de ação social, então Honneth propõe a ideia das formas de desrespeito social como motivos para os conflitos sociais.

Esse esforço sistemático de caracterização de uma fonte pré-teórica no interior de uma teoria do reconhecimento encontra prosseguimento e especificação na reatualização da Filosofia do Direito de Hegel e do consequente delineamento de uma teoria normativa da justiça própria do horizonte da eticidade moderna. Em "Sofrimento de Indeterminação" "Honneth volta a enfatizar o papel da eticidade e das formas do reconhecimento no que concerne à elucidação das esferas sociais como compondo a

\footnotetext{
${ }^{8}$ Honneth, 2003.

${ }^{9}$ Honneth, 2007.
} 
base das esferas institucionais. Neste momento Honneth objetiva contrapor uma solução hegelina às teorias kantianas da justiça, como a de John Rawls e ao mesmo tempo dar novo redirecionamento à teoria social de Habermas ${ }^{10}$. Para tal empreende uma atualização "indireta" da Filosofia do direito de Hegel, isto é, reconstrói apenas os conceitos de "eticidade" e "espírito objetivo", em detrimento da lógica e do "Estado"11. O conceito de espírito objetivo de Hegel, mesmo depurado das "pressuposições metafísicas", serve como sustentáculo para o delineamento dos "fundamentos racionais" da realidade social, assim como das patologias sociais. Já os padrões e formas de reconhecimento inscritos na eticidade são tratados nesse novo contexto também como "esferas de ação". O quadro de exigências e pretensões que a eticidade mantém para si é composto, além das práticas de interação que devem garantir a autorrealização, também daquelas classes diferentes de ações que devem garantir o reconhecimento recíproco e daquelas que devem garantir o processo de formação correspondente, sendo que entre estas três principais condições deve haver uma relação intrínseca de condicionamento mútuo.

Tal quadro da eticidade representa as condições necessárias para a autorealização individual, ou ainda, para a realização da liberdade como um todo. Como a intenção de Honneth não é conceber a liberdade como simples ideia abstrata ou apenas relativa à autonomia moral do ser humano, tal como na tradição kantiana, mas concebêla inerentemente à ordem social das sociedades modernas, o texto honnethiano busca fundamentar princípios de justiça a partir do diagnóstico crítico dos efeitos das unilateralizações tanto da liberdade jurídica quanto da liberdade moral nos contextos da vida social. Partindo de Hegel, ele caracteriza a absolutização de cada tipo de liberdade como dando vazão a um "sofrimento de indeterminação", patologia que aflige as esferas sociais modernas tão logo um dos aspectos da liberdade seja unilateralizado, e a liberdade não seja tomada em todo o seu escopo relativo à auto-realização individual. Trata-se nesse momento de elucidar categorialmente as esferas sociais em relação aos seus aspectos normativos que dão base e sustentação às normas juridicamente institucionalizáveis na modernidade, além de constituírem os "alvos" imediatos das patologias que afligem a modernidade.

\footnotetext{
${ }^{10}$ Lima, 2008.

${ }^{11}$ Honneth deve evitar o conceito antidemocrático do Estado e também as implicações da fundamentação metafísica constitutiva da lógica do pensamento hegeliano. Cf. Honneth,2007,pág.48-49.
} 
Assim tanto em "Crítica do Poder", quanto no delineamento da "luta por reconhecimento" ou na reatualização da "eticidade" e do "espírito objetivo" de Hegel, Honneth propõe uma elucidação categorial da realidade social que perpassa a teorização acerca de fontes da experiência que sejam “interiores" às próprias práticas sociais, caracterizadas pela ideia de reconhecimento. Nesse interim o presente trabalho pretende elucidar o conceito de "social" que perpassa todo o trabalho de Honneth e o permite fundar uma teoria moderna do reconhecimento e justiça. Esse conceito deve ser esclarecido a partir de uma concepção pós-idealista da noção hegeliana da realização da razão, noção esta que o permite derivar o caráter crítico normativo de sua teoria a partir da própria realidade social. Para Habermas o conceito de racionalização social de Marx até Horkheimer e Adorno teria sido sempre pensado em termos de uma alienação ou reificação da consciência. Isto se deve, segundo ele, a uma filosofia da consciência que se ancora na ideia de que o progresso e a evolução social podem ser estudados a partir das funções que cabem a um sujeito individual e, ou, coletivo ${ }^{12}$. Para Honneth, no entanto, embora na abordagem teórico-comunicativa de Habermas, as patologias sociais da modernidade sejam pensadas a partir do que ele chama "colonização do mundo social", recuperando assim um aspecto esquecido pela Teoria Crítica em seu passado: a articulação entre o sistema e o mundo da vida cotidiana, ele não foi capaz de superar uma visão instrumentalizada das relações sociais e das ações humanas. Isso porque, para a teoria do agir comunicativo, os conflitos sociais estão fundamentados num modelo dual de dominação teórico linguístico, ou seja, na mediação precária do diálogo entre os grupos sociais e as instituições. Assim Honneth parece responder ao mesmo dilema imposto a Habermas pela aporia da crítica da razão instrumental: como se pode reabilitar o conceito de racionalidade universal sem cair no pensamento da totalidade, evitando ao mesmo tempo a reificação? ${ }^{13}$ Para Honneth somente uma racionalidade social pensada a partir de uma teoria do reconhecimento pode superar a aporia da Teoria Crítica.

A elucidação do conceito de "social" ganha especial relevância uma vez que marca a inserção de Honneth no debate acerca da Teoria Crítica, e também constitui fundamento a partir do qual pretende garantir o momento transcendente junto ao

\footnotetext{
${ }^{12}$ Habermas, 2012, p.685.

${ }^{13}$ Essa é a questão que Habermas pensa poder resolver no cap. IV da Teoria do Agir Comunicativo, partindo da análise dos autores ocidentais da tradição marxista.
} 
momento imanente do seu modelo crítico, isto é, Honneth pretende atribuir a processos sociais de integração uma carga normativa. O especificamente sociológico da Teoria do Reconhecimento parece não estar associado a análises sociológicas tradicionais. A importância deste para seu modelo não deve ser buscada na investigação de contextos sociais específicos, mas na dimensão intersubjetiva da integração social, de modo que esta integração mesma se revista de um caráter normativo. Honneth parece ter em mente um padrão normativo de socialização que garanta tanto a formação da subjetividade, quanto a possibilidade de uma identidade formada por meio do contato entre subjetividades, mantendo suas particularidades, participar das esferas universalizadas da vida social. Nesse sentido, seria possível ver na negação ao reconhecimento das particularidades ou dos direitos os motivos para o conflito social quanto esta negação desrespeitasse grupos sociais. Esse parece ser o horizonte que Honneth tem em vista ao formular seu modelo crítico a partir da atualização do conceito hegeliana do reconhecimento.

Para elucidar o conceito do "social" que marca o desenvolvimento do modelo crítico proposto por Honneth este trabalho é dividido em três partes. A primeira parte é dedicada a esclarecer o que Honneth chama de "déficit sociológico" da tradição crítica. A partir da crítica que ele faz a Horkheimer, Adorno, Foucault e Habermas em sua obra Crítica do Poder, pretende-se evidenciar a necessidade percebida por Honneth de uma atualização das bases normativas da Teoria Crítica com vistas a salvaguardar seu potencial prático-crítico. Na segunda Parte, o intento é apresentar de forma sólida a ideia de reconhecimento com a qual Honneth deseja fundamentar uma teoria social crítica. Para tanto focaremos na obra Luta por Reconhecimento. Serão apresentados, na sequência, os argumentos por meio dos quais Honneth acredita que o conceito de reconhecimento seja o mais apto a sustentar uma teoria social, sua tipologia das relações sociais que estruturam as formas de reconhecimento e as formas de negação destas relações encontradas na realidade social. Por fim, na terceira parte pretende-se esclarecer os desdobramentos da formulação da Teoria do Reconhecimento em uma Teoria da Justiça como eticidade desenvolvida em Sofrimento de Indeterminação. 


\section{PARTE I: DÉFICT SOCIOLÓGICO DA TEORIA CRÍTICA}

\section{A IDÉIA ORIGINAL DE HORKHEIMER E APORIAS DE UMA FILOSOFIA DA HISTÓRIA}

Na primeira parte de Crítica do Poder, intitulada "A incapacidade para análise social: as aporias da teoria crítica"14, Honneth segue a formulação original da Teoria Crítica delineada por Horkheimer em "Teoria Tradicional e Teoria Crítica"15, bem como sua concretização na forma de um programa de um materialismo multidisciplinar que passa a orientar as pesquisas do instituto à época. Segundo Honneth, a tentativa de justificar as reivindicações de uma Teórica Crítica da sociedade é marcada por ambiguidades provocadas pelos pressupostos assumidos por Horkheimer de uma filosofia da História centrada no trabalho. Isso se desdobra, de acordo com Honneth, em um "déficit sociológico" do seu programa de um materialismo interdisciplinar.

Em "Teoria Tradicional e Teoria Crítica”, Horkheimer tenta expor as raízes práticas do pensamento moderno (que ele chama de tradicional) com vista a fundamentar a Teoria Crítica como expressão autoconsciência do processo de emancipação política e social. Horkheimer toma seu modelo de ciência moderna em conexão com a reflexão de Descartes sobre o método. De acordo com esse modelo as teorias científicas têm por tarefa determinar um conjunto de declarações dedutivamente adquiridas que são hipoteticamente aplicadas à realidade empírica observada. A explicação do estado empírico das coisas é possível na medida em que estas declarações hipotéticas são confirmadas pela observação da realidade experimentalmente controlada. Horkheimer não está interessado nas correções e modificações desse modelo pela filosofia da ciência pós-cartesiana ${ }^{16}$, mas sim em captar o modo como a idade moderna imagina a relação entre teoria científica e a realidade. Para ele esta relação é definida pela seguinte característica:

Tem-se sempre, de um lado, o saber formulado intelectualmente e, de outro, um fato concreto que deve ser subsumido por esse saber

\footnotetext{
${ }^{14}$ Honneth,1991, traduzido de: "The incapacity for Social Analysis: Aporias of Crítical Theory".

${ }^{15}$ Horkheimer, 1968a.

${ }^{16}$ Horkheimer, 1968a.
} 
subsumir, isto é, este saber estabelecer a relação entre a mera percepção ou constatação do fato concreto e a ordem conceitual do nosso saber chama-se explicação teórica ${ }^{17}$.

Assim os processos naturais e sociais são progressivamente previstos e controlados na medida em que cada vez mais segmentos da realidade tornam-se parte de uma série de proposições, ou seja, são capturados por uma rede de declarações hipotéticas. Para Horkheimer, essa função de dominação inerente aos processos da teoria científica revela seu contexto constitutivo. A capacidade de predizer, controlar e dirigir processos reais, é igualmente pressuposta à realização do trabalho social. Assim Horkheimer passa a conceber as teorias científicas "como parte do processo prático de reprodução em que a espécie humana preserva a sua vida, através do aumento do controle sobre seu ambiente natural e do seu próprio mundo social" ${ }^{\text {"18 }}$. No entanto, segundo Horkheimer, ao contribuir com os processos de reprodução social, na medida em que se torna útil às relações de produção, o conhecimento científico acaba se coisificando e ideologizando. O que impede com que a ciência moderna perceba seu próprio contexto constitutivo, ou seja, a teoria moderna forma sobre si mesma a imagem de pureza, isenção e racionalidade, não leva em conta que ela própria e a forma como ela se desenvolve através do tempo repousa no processo de vida social.

Ao derivar a origem da teoria moderna da ciência como parte do processo prático de reprodução da espécie humana, Horkheimer assume, diz Honneth, implicitamente a ideia de que as conquistas do trabalho social é que liberta os humanos do poder da natureza e conduz o desenvolvimento organizado da civilização capaz de dominá-lo. A visão de pureza da teoria moderna também é esclarecida por Horkheimer a partir do mesmo referencial teórico. Esse auto-engano aparece segundo ele, por um lado, como produto das condições predominantes das forças de produção: não só o objeto específico, mas também o tipo e a maneira como a teoria entra em contato com a realidade é moldado pelas condições do trabalho social ${ }^{19}$. E, por outro lado, a teoria tradicional simplesmente refletiria a falta de consciência humana em relação ao seu papel histórico constitutivo devido às condições matérias de produção:

\footnotetext{
${ }^{17}$ Horkheimer, 1968a, p. 120.

${ }^{18}$ Honneth, 1991, p.6.

${ }^{19}$ Horkheimer,1968a.
} 
A produção da vida social ainda não foi entendida em si mesma na história da espécie como uma síntese da realização cooperativa de todos os sujeitos trabalhadores. É claro que o processo de produção esboçado, orientado para a dominação da natureza, até agora tem trazido progresso histórico, mas os sujeitos atuantes não reconheceram suas realizações comuns constitutivas. Essa falta de consciência é simplesmente continuada na auto-compreensão da teoria tradicional. Da mesma forma que a espécie humana não tem conhecimento do contexto historicamente constitutivo a que pertence, como um resultado de todas as suas realizações cognitivas. ${ }^{20}$

Horkheimer, portanto, segundo Honneth, assume como pressuposto de sua construção teórica uma estrutura interpretativa derivada da filosofia da História retirada do modelo de "alienação do trabalho" que constitui base da crítica do capital de Marx. O processo civilizatório da história é igualado à progressiva dominação da natureza da qual a espécie estaria separada como resultado de sua falta de compreensão histórica, mas tão logo retome sua consciência pode conduzir positivamente a dominação racional da natureza. Horkheimer, portanto, ainda vê a teoria tradicional em sua função social positiva $^{21}$, que é o movimento de libertação frente à natureza. Para Honneth, no entanto, este quadro interpretativo utilizado por Horkheimer consiste em uma interpretação simplista da contradição entre as forças de produção e relações de produção: "As forças produtivas são vistas como um potencial emancipatório, ao passo que a organização não planejada no capitalismo é considerada apenas como a expressão do auto-engano humano." 22 No entanto, é a partir dessa linha argumentativa que ele agora pretende fundamentar sua concepção de Teoria Crítica.

Depois de conceber a Teoria Tradicional como resultado de um processo civilizatório contraditório, Horkheimer define a primeira característica da Teoria Crítica. Na medida em que aquela acredita que pode fundamentar seus métodos através de critérios imanentes ao conhecimento por si só, compreende-se como separada de sua origem prática, a Teoria Crítica deve ser continuamente consciente de seu contexto constitutivo. Horkheimer situa a Teoria Crítica como uma força participante do desenvolvimento da humanidade, ao mesmo tempo em que lembra que o contexto de

\footnotetext{
${ }^{20}$ Honneth, 1991, pág.7.

${ }^{21}$ Honneth, 1991.

${ }^{22}$ Honneth,1991, pág.9.
} 
existência da teoria é a própria realidade social. Para Honneth, no entanto, essa formulação do modelo crítico impõe uma questão:

como pode Horkheimer agora definir com maior precisão conceitual o contexto prático a qual a teoria crítica está constitutivamente relacionada, se seu ponto de partida na filosofia da história ainda reduz toda a prática social à atividade produtiva da espécie humana? ${ }^{23}$

Ou seja, como Horkheimer pretende diferenciar a Teoria Crítica da Teoria Tradicional quanto a seu contexto de existência, se ambas permanecem centradas no paradigma da apropriação da natureza por meio do trabalho? Ao estabelecer a ligação entre Teoria Tradicional e o processo de trabalho, Horkheimer tenta mostrar que o conhecimento fornecido por esse tipo de teoria refere-se somente à explicação e previsão de processos empíricos e "não contém o momento de reflexão que seria necessário para por em questão o intervalo entre a ordem social e o desenvolvimento das forças produtivas" 24 .

Diante desse quadro, Horkheimer sugere um segundo modelo interpretativo das condições constitutivas da Teoria Crítica. Este não é mais concebida como um componente imanente do processo de desenvolvimento humano, mas como expressão teórica de uma "atividade crítica pré-científica" em que a própria sociedade é posta em questão. Assim a teoria não precisa se aplicar à realidade, apesar de já estar presente nesta. Neste sentido a Teoria Crítica teria uma relação consciente com a prática por saber que faz parte da sociedade como seu objeto ${ }^{25}$. Esse aspecto leva Horkheimer a estabelecer a segunda característica essencial da Teoria Crítica, a relação inseparável entre sujeito e objeto permite que, além do conhecimento das condições práticas e do contexto de sua origem, a Teoria Crítica seja força atuante no processo prático político $^{26}$. Com sua nova formulação Horkheimer apresenta um tipo de atividade humana que não tem a natureza, mas "a própria sociedade", como seu objeto. Ele está preocupado não com uma extensão de dominação da natureza à vida social como controle social, mas com uma atividade que vai além do sistema socialmente estabelecido funcionalmente, ou seja, um tipo de atividade prática socialmente

\footnotetext{
${ }^{23}$ Honneth, 1991, pág.10.

${ }^{24}$ Honneth, 1991, pág. 11.

${ }^{25}$ Honneth, 1991.

${ }^{26}$ Honneth,1991, pág. 14.
} 
transformadora a qual a Teoria Crítica está em si conectada. Para Honneth, no entanto, "esta formulação, que inequivocamente inclui a Teoria Crítica em uma dimensão de luta social no lugar de uma dominação social da natureza, drasticamente revela a disparidade entre sua caracterização epistemológica e a filosofia da história por ele assumida."27

Esse novo modelo, diz Honneth, invoca um conceito de práxis social, que é mais abrangente do que o permitido por sua concepção de filosofia da História. Ao derivar a Teoria Crítica de uma atividade prático-crítica, Horkheimer tem em vista uma atividade prática socialmente transformadora, à qual a Teoria Crítica é em si conectada. Esse argumento situa a Teria Crítica em uma dimensão de luta social, o que não tem lugar na filosofia da História pressuposta por Horkheimer:

esse quadro reduz o curso da história humana ao quase natural processo de desenvolvimento da dominação da natureza, não há possibilidade conceitual para uma forma diferente de práxis social que não visa a constante expansão produtiva de auto-preservação, mas a um novo modo de organização da sociedade auto-preservação. ${ }^{28}$

O desenvolvimento sócio-cultural passa a ser visto tanto a partir da esfera de produção social quanto da esfera de conflito social, sem que os pressupostos da sua filosofia da História seja revista. Como consequência, de acordo com Honneth, Horkheimer acaba por situar a atividade crítica no interior de uma noção de conflito simplificada que faz referência apenas à dimensão da organização da produção social. $O$ conflito social, ao contrário do domínio da força da natureza, repousa num processo de experiência historicamente mediado de percepção das classes desfavorecidas, de sua situação histórica. Assim a atividade crítica surge como experiência subjetiva de uma injustiça sofrida no processo de luta relacionada à sobrevivência. Esta injustiça é representada pela distribuição do produto de trabalho entre as classes sociais. Dessa forma apenas os grupos excluídos são vistos como dotados de capacidade crítica ${ }^{29}$. Para Honneth, portanto, embora Horkheimer situe a atividade crítica no âmbito da ação social, este não a considera no seu sentido amplo, restringe sua análise ao âmbito da organização social da produção, não considera outras esferas da atividade humana.

\footnotetext{
${ }^{27}$ Honneth,1993,pág 15.

${ }^{28}$ Honneth, 1991. Pág 13.

${ }^{29}$ Honneth,1991.
} 
A atividade crítica permanece indefinida, o conflito não diz respeito à ação social propriamente dita, mas à luta de classe, Horkheimer omite completamente a dimensão da vida social, na qual deveria estar situada esta atividade crítica a fim de participar do processo cooperativo de superação das injustiças sofridas. Ele, portanto, não trata o conflito social como esfera autônoma de reprodução da vida social. O resultado, de acordo com Honneth, é a perda da dimensão social no modelo que Horkheimer pretende criar $^{30}$.

Assim o modelo de Horkheimer, diz Honneth, permanece incapaz de escapar à determinação estrutural das forças produtivas, ainda que, para realização da tarefa crítica que havia se proposto, uma análise mais ampla da atividade humana fosse necessária. Esta situação torna-se ainda mais complicada devido ao diagnóstico oferecido por ele sobre as condições políticas e sociais de seu tempo. Para Horkheimer mesmo o proletariado não está livre dos efeitos da reificação e nem da ideologia totalitária de Hitler ou de Stalin:

nesta sociedade tampouco a situação do proletariado constitui garantia para a gnose correta. Por mais que sofra na própria carne o absurdo da continuação da miséria e do aumento, da injustiça, a diferenciação de sua estrutura social estimulada de cima, e a oposição dos interesses sociais e de classe, superadas apenas em momentos excepcionais, impedem que o proletariado adquira imediatamente consciência disso. Ao contrário, também para o proletariado o mundo aparece na sua superfície de uma outra forma. ${ }^{31}$

Este diagnóstico leva Horkheimer a formular a pergunta em torno da qual irá girar a pesquisa do Instituto: quais os mecanismos psíquicos responsáveis por manter a luta de classes (ou a tensão entre as classes) em estado latente, apesar de ela tender ao conflito devido à situação econômica? A sua ideia era a de uma pesquisa capaz de fornecer diagnósticos filosóficos do tempo presente e integrá-los a projetos de pesquisas particulares cujo intento fosse mais prático. Esta construção foi chamada por ele de materialismo interdisciplinar. Na construção deste modelo, Horkheimer se vale da noção de capitalismo de Estado, desenvolvida por Friedrich Pollock, dos estudos

\footnotetext{
${ }^{30}$ Honneth,1991.

${ }^{31}$ Horkheimer, 1968a, pág.134-5 . O diagnóstico de Horkheimer, porém, não se limita à falência da capacidade revolucionária do capitalismo, mas também na afirmação, apoiada nas pesquisas de Friedrich Pollock, de que a fase liberal do capitalismo havia sido superada em prol de uma organização do capitalismo a partir do Estado. Cf. Horkheimer 1968a.
} 
psicanalíticos de Erich Fromm e do conceito de sociologia cultural. A reprodução social passa a ser analisada a partir de imperativos estruturais vistos por Pollock, impulsos individuais da teoria de Fromm e da ação cultura. No entanto, de acordo com Honneth, por manter-se preso a mesma estrutura de explicação histórica baseada unicamente no trabalho, Horkheimer não consegue conceber a vida social de maneira apropriada: a economia assume o papel preponderante, cabendo às categorias psicológicas e ação cultural a explicação antes da dominação e passividade de grupos considerados abstratamente.

Para Horkheimer, no entanto, diante das mudanças internas sofridas pelo capitalismo desde sua era liberal, uma teoria social baseada unicamente em conceito de uma teoria econômica não é suficiente para investigar a causa da latência dos conflitos sociais. Em consonância com os trabalhos de Friedrich Pollock, que estava no instituto à época, Horkheimer vê na fase pós-liberalismo do capitalismo um modo de produção no qual o Estado assume progressivamente a função que antes pertencia ao mercado, assim o controle deixa de ser econômico e passa a ser político, favorecendo dessa maneira o direcionamento ideológico da sociedade. Esta forma de Estado, construída como tipo ideal weberiano, possui forma totalitária ou democrática. A diferença entre eles diz respeito, antes, ao tipo de dominação política que eles estabelecem, como são os casos do nazismo e do capitalismo liberal norte-americano. Horkheimer, no entanto, pretende construir um modelo em que a dominação não se imponha de maneira tão unilateral e, por isso traz para o âmbito do materialismo interdisciplinar a psicanálise, cuja tarefa seria explicar as dinâmicas psíquicas que ocorrem dentro destes novos tipos de relações sociais que a Teoria Crítica diagnosticara. Dessa maneira, seria possível entender a latência da luta de classes também por meio da consideração de que a manipulação e o controle dos instintos nem sempre se baseiam em escolhas racionais, uma vez que a situação de opressão também encerra a repressão de desejos de compensação, desejos esses que, aliás, poderiam servir como motivos para a ação. Assim, portanto, Horkheimer adiciona a psicanálise ao seu modelo de Teoria Crítica para enfrentar o desafia representado por comportamentos não racionais encontrados na realidade, isto é, os processos de socialização individual que adéquam o comportamento dos indivíduos as relações já existentes de opressão. 
Horkheimer toma como modelo a psicologia social de Erich Fromm. Segundo este as demandas institucionais do sistema capitalista de trabalho são transportadas para os adolescentes pelos pais:

práticas educativa parentais que refletem a força externa da sociedade dentro da família corrigem o desenvolvimento psicossexual da criança ao nível adequado para o sistema socialmente necessário de comportamento. Em contraste com isso, os elementos instintivos que se esforçam para ir além das formas de expressão de valor na família ou são reprimidos ou sublimados - as aspirações libidinais do sujeito adolescente são incorporados nos quadros socialmente desejados de ação. $^{32}$

Para Honneth, no entanto, ao assumir o modelo de Fromm, Horkheimer incorre em um funcionalismo fechado, que anula a dimensão da ação social. A família que representa o único contexto comunicativo da sociedade aparece como mera função dos processos econômicos, apenas reflete os imperativos funcionais da economia capitalista como restrições de comportamento. Assim, em oposição às forças sistêmicas da economia não é concedido um único excedente libidinal a necessidades individuais, nem qualquer autonomia a ação social. Para Honneth, tanto as análises derivadas da inserção da Economia como disciplina fundamental, quanto da psicologia no quadro da Teoria Crítica, apontam para uma inexistência de qualquer tipo de reação e disposição contrária à dominação ou à fixação de comportamentos. A vida social é vista de maneira abstrata de forma que não existe um espaço de análise para as situações nas quais o mundo social se reproduza por meio daquela atividade criativa que Horkheimer havia situado no centro de seu modelo e que conteria o germe da atividade crítica.

Para superar essa limitação, Horkheimer adiciona uma terceira esfera ao modelo crítico do materialismo interdisciplinar que seria responsável pela análise dos espaços sociais existentes entre os imperativos estruturais vistos por Pollock e os impulsos individuais da teoria de Fromm. No seu discurso de posse, Horkheimer reivindica a "cultura" como terceira dimensão da reprodução social, assim juntamente com o sistema de trabalho social e socialização dos instintos individuais, essa esfera deve ser igualmente considerada no programa de uma ciência social interdisciplinar.

\footnotetext{
${ }^{32}$ Honneth, 1991, pág. 23.
} 
Para Honneth, essa esfera da cultura reivindicada por Horkheimer denotaria um espaço de ação social no qual grupos sociais criam valores comuns e os objetivam em relações cotidianas e interações simbólicas ${ }^{33}$. Essa dimensão conservaria os padrões de orientações de valores que exerceriam a função mediadora entre o sistema de trabalho social e a formação dos motivos individuais, atuando como "cimento da sociedade".

No entanto, para Honneth, com "Autoridade e Família” editado em 1936, o conceito de "cultura" deixa de se referir ao domínio específico da ação social e passa a designar a esfera institucional de socialização responsável pela produção dos comportamentos requeridos pela vida em comum. Ao atribuir as práticas educativas parentais, currículos escolares, rituais religiosos a função mediadora entre exigências comportamentais de produção social e o sujeito, no lugar da ação cooperativa de padrões normativos de orientação, Horkheimer abandona o conceito de ação cultural e passa a considerar as instituições culturais como paradigma do conceito de cultura.

o sistema referencial decisivo aqui restringe o conceito da cultura à instituições permanentemente fixas que são aparentemente removidas do curso cotidiano da ação orientado pela produção cooperativa de padrões normativos, ou seja, ação cultural, mas sim a função de socialização das instituições formadoras, as instituições de cultura, fornece o verdadeiro paradigma para a qual o segundo conceito de Horkheimer da cultura é orientado ${ }^{34}$.

Para Honneth é a concepção limitada da história que obriga Horkheimer a comprimir o conceito de ação cultural à estrutura limitada do trabalho social. Somente uma "estrutura institucional" seria capaz de garantir ao nível da sociedade as motivações exigidas pela organização do trabalho e apoiar ideologicamente a distribuição de privilégios atuando como fator estabilizador dos instintos individuais. Dentro dessa estrutura conceitual, portanto, desaparece o modo de ação cultural e a referência à ação cooperativa de produção e manutenção de orientações de grupos específicos. Toda ação humana é pensada em sua relação com o trabalho social. ${ }^{35}$

\footnotetext{
${ }^{33}$ Honneth,1991.

${ }^{34}$ Honneth,1991,pág. 27.

${ }^{35}$ Honneth, 1991.
} 
Assim, de acordo com Honneth, a visão que Horkheimer sustenta sobre a ação social se mantém presa a uma concepção totalizante de trabalho social, ainda que atenta a diferentes influências sobre o comportamento humano. A teoria interdisciplinar de Horkheimer, segundo Honneth, consegue apontar meios de socialização em diferentes esferas, o que lhe permite apresentar uma visão sobre a latência do conflito de classes, mas não abre espaços para um entendimento efetivo da dinâmica social cotidiana, ou seja, a Teoria Crítica, da forma como foi fundamentada por Horkheimer, tendo sempre em vista sua concepção da filosofia da História, não reservaria um espaço analítico para responder à questão sobre a latência da luta de classes, na medida em que suas estruturas não permitem que se pense o conflito social de modo amplo e, consequentemente, o intento emancipatório desta teoria não poderia ser realizado. As estruturas de ação cultural ou de conflito social, portanto, não podem ser desenvolvidas nem ao nível do modelo marxista de Horkheimer, baseado no trabalho social, e nem ao nível do modelo psicanalítico de socialização dos instintos, já que ambos são tomados como áreas nas quais não há espaço para a ação cotidiana propriamente dita, diz Honneth. Para Honneth, o modelo de Horkheimer sofre de uma supervalorização da dimensão histórica do trabalho social. Este é o problema inicial da noção mesma de filosofia da História com que Horkheimer lida a fim de fundamentar o que seria a Teoria Crítica e, por isso mesmo, é o motivo pelo qual ele não pode lidar com as proposições que havia se colocado. A força com que o conceito de filosofia da História se estende sobre sua obra é tão grande que, já nesta fase da fundação da Teoria Crítica, Horkheimer é obrigado a comprimir a ação cultural e a prática crítica naquela estrutura limitada ao trabalho social e à socialização dos indivíduos.

Para Honneth, portanto, a Teoria Crítica sofre desde sua fundação da ausência, devido à supervalorização do conceito de filosofia da História, de uma dimensão na qual o conflito e a atividade crítica pudessem se desenvolver plenamente, e assim fundamentar a análise de que a produção e a organização material do mundo social não respeitariam regras naturais de acumulação e ampliação, mas seriam fruto de uma luta na qual os interesses dos grupos na riqueza produzida motivariam suas ações cotidianas e influenciariam as formas de distribuição desta riqueza. Ou seja, a Teoria Crítica sofreria desde o início daquilo que Honneth chamou de "déficit sociológico" que a impediria de trabalhar profundamente os conceitos de ação social necessários para a construção de um modelo emancipatório, algo que permaneceria marcado neste modelo 
mesmo com as tentativas de Horkheimer de integrar análises psicológicas e culturais ao seu modelo teórico.

\title{
2. DIALÉTICA DO ESCLARECIMENTO: FILOSOFIA DA HISTÓRIA COMO DOMINAÇÃO
}

A publicação da "Dialética do Esclarecimento" em 1944, livro escrito por Adorno e Horkheimer no exílio americano durante a segunda guerra mundial, marca , segundo Honneth, o deslocamento do centro do pensamento crítico de Horkheimer para Theodor W. Adorno. A preocupação central de Adorno não é a mesma de Horkheimer: por que as esperanças revolucionárias não foram cumpridas? Mas o horror ao processo civilizatório cujo resultado é a sociedade contemporânea. Seu pensamento não é guiado pela perda das esperanças revolucionárias, mas pelas experiências de dominação que marcam seu tempo. Neste sentido a determinação histórica-cultural do presente é mais clara na obra de Adorno, na qual configura campo central da sua filosofia da História, do que na obra de Horkheimer, onde ela funciona como pano de fundo. Adorno entende o horror do presente como destino cultural marcado pela possibilidade de convergência histórica mundial dos processos de dominação. Por isso, ele entende seu próprio tempo como uma instância de dominação totalizada enquanto Horkheimer ainda não chega essa conclusão.

\begin{abstract}
A derrota da revolução russa com o surgimento da burocracia ditatorial stalinista, a fundação terrorista do aparato de poder fascista na Europa, e o crescimento aparentemente interminável do capitalismo americano são para ele formas pouco distinguíveis de desenvolvimento de um processo histórico, que culmina em um sistema de dominação total. Diferente de qualquer outro, a teoria social de Adorno é motivada pela questão filosófica-histórica sobre a possibilidade desta convergência histórico-mundial. ${ }^{36}$
\end{abstract}

As semelhanças entre sistemas de dominação que se tornam visíveis a sua época configuram, portanto, ponto de partida a partir do qual Adorno reconstrói sua filosofia da História. Esta tem como tarefa expor o processo de desenvolvimento da

\footnotetext{
${ }^{36}$ Honneth, 1991, pág. 35-36.
} 
civilização como processo de auto-regressão humana, uma vez que o progresso técnico das forças produtivas maquiaria o ato extensivo de regressão contido no movimento de dominação da natureza. Segundo Honneth, essa filosofia a partir da qual Adorno espera esclarecer a origem da dominação total marca o núcleo teórico que orienta a "Dialética do Esclarecimento",37.

A construção filosófico-histórica da Dialética do Esclarecimento tem como base uma teoria dominação tomada a partir do controle instrumental da natureza. Para Adorno e Horkheimer, todas as formas de dominação são derivadas da lógica de identidade da razão instrumental, ou seja, da subsunção do particular pelo universal, modelo original de dominação ${ }^{38}$. Essa perspectiva, de acordo com Honneth, permite uma aproximação da Dialética do Esclarecimento à Teoria Tradicional de Crítica da Cultural; a tecnologia e a ciência moderna enquanto instituições de dominação da natureza são interpretadas como sinal de decadência da civilização. $O$ desenvolvimento das forças produtivas é interpretado, por um lado, como desdobramento dos atos do processo original de intervenção orientado para o controle dos processos naturais, sob a perspectiva de auto-conservação e, por outro lado, como processos que transformam a natureza em simples objeto de controle, a qual o homem paga com a auto-alienção. É esse entrelaçamento entre a preservação e a alienação da espécie humana que constitui, de acordo com Honneth, o tema central de desenvolvimento na Dialética do Esclarecimento. Para explicar essa relação intrínseca Adorno e Horkheimer investigam primeiro a origem dinâmica dos processos de reificação e depois associa esse processo a uma teoria do ego.

O conceito de racionalidade instrumental constitui, portanto, a chave a partir do qual Adorno e Horkheimer explicam a origem da dinâmica da regressão da civilização. Horkheimer e Adorno desenvolvem esse argumento a partir da generalização da crítica de Marx do capital: não só a história do capitalismo liberal, mas todo o curso da civilização é visto sob a perspectiva teórica de uma crescente reificação ${ }^{39}$. A troca de mercadoria, que segundo a tradição marxista fornece os mecanismos abstratos que formam a consciência burguesa, constitui na Dialética do Esclarecimento apenas a forma historicamente desenvolvida da racionalidade

\footnotetext{
${ }^{37}$ Adorno e Horkheimer, 2006.

${ }^{38}$ Honneth,1991.

${ }^{39}$ Honneth,1991.
} 
instrumental $^{40}$. Para Adorno e Horkheimer o modelo de racionalidade instrumental é formado no processo humano inicial de auto preservação em oposição à natureza externa. Esse processo é descrito como um processo gradual de substituição das formas miméticas de ação:

a civilização havia substituído a adaptação orgânica ao outro, isto é, o comportamento propriamente mimético, pelo controle organizado da mimesis e, por fim, na fase de histórica, pela prática racional, isto é, pelo trabalho ${ }^{41}$.

O abandono da experiência mimética socialmente organizada em direção à intervenção manipuladora da natureza ao mesmo tempo em que abstrai o medo aterrador dos processos naturais implica, no entanto, uma restrição sensorial dos seres humanos. A regularidade dos processos naturais que passa a ser utilizada como meio de sobrevivência implica na restrição da mutiplicidade sensorial a conceitos que possuem a função interventora.

Pensando, os homens distanciam-se da natureza a fim de torná-la presente de modo a ser dominada. Semelhante à coisa, à ferramenta material- que pegamos e conservamos em diferentes situações como a mesma, destacando assim o mundo como o caótico, multifário, disparatado do conhecido, uno, idêntico- o conceito é a ferramenta ideal que se encaixa nas coisas pelo lado por onde se pode pegá-las. ${ }^{42}$

O comportamento mimético socialmente organizado através do qual as formas de vida pré-humanas pretendem influenciar os eventos naturais que lhes incitam medo, é substituído pelo controle profilático da natureza. A regularidade dos processos naturais é transformada em meio para aquisição do próprio sustento, mas somente com a interação instrumental sobre a natureza que a realidade do meio natural é transformada

\footnotetext{
40 Para Honneth, com essa generalização Adorno e Horkheimer excluem a possibilidade de desenvolvimento da civilização a partir dos padrões de organização de uma interação intersubjetiva que passa a ser explicado apenas a partir da filosofia restrita a processo de reificação.

${ }^{41}$ Adorno e Horkheimer, 2006.pág.149.

${ }^{42}$ Adorno e Horkheimer,2006, pág.43.
} 
em realidade objetiva. A ação instrumental filtra a multipilicidade do ambiente natural $^{43}$. Apenas componentes que desempenham a função interventora podem ser considerados, a objetivação de realidade implica uma redução sensorial do sujeito. Para Honneth, no entanto, esse argumento antropológico liga a natureza congelada em pura objetividade a um processo de alienação dos instintos.

Para Honneth, este argumento antropológico, encontrado em diversas passagens da Dialética do Esclarecimento, está em conexão com a filosofia antropológica de Arnold Gehlen e fundamenta a possibilidade de uma explicação alternativa da filosofia da história. Gehlen concebe a atividade de orientação conceitual como uma atividade compensatória de déficit dos instintos. Assim, Horkheimer pode associar a reificação da natureza a uma atividade compulsória que reproduz a força da natureza que o trabalho deveria evitar. A partir desse aparato conceitual, Adorno e Horkheimer, podem conceber a ciência e a tecnologia, instituições mais avançadas da sociedade moderna, uma vez que representam a continuação da atividade conceitual, como reprodução da atividade mágica que a atividade conceitual deveria eliminar.

A ciência é repetição, aprimorada como regularidade observada e conservada em estereótipos. A fórmula matemática é uma regressão conscientemente manipulada, como já o era o rito mágico; é a mais sublime modalidade do mimetismo. A técnica efetua a adptação ao inanimado a serviço da natureza externa, mas através da automatização dos processos espirituais, isto é, através de sua trasformação em processos cegos. Com seu triunfo, as manifestações humanas tornam-se ao mesmo tempo controláveis e compusivas. Da assimilação à natureza resta apenas o enrijecimento contra ela. ${ }^{44}$

Para mostrar que a auto alienação da humanidade é uma consequência do processo civilizatório pelo qual a humanidade domina a natureza, Horkheimer traz à tona uma teoria do ego. Tal como no conceito de "ação cultural" o processo de formação da identidade é explicado em termos apenas da relação entre o indivíduo

\footnotetext{
${ }^{43}$ Honneth, 1991.

${ }^{44}$ Adorno e Horkhiemer,2006, pág.150.
} 
consciente e o meio que o cerca. Para Horkheimer o ego é produto da capacidade do sujeito de distinguir entre as suas impressões externas e suas experiências intrasensoriais. Surge como antítese à natureza a partir do momento em que passa experimentar-se como órgão unificado de suas experiências, entende-se como antítese a natureza fixa. Para Honneth, essa dimensão representa um dos poucos momentos na Dialética do Esclarecimento em que sua concepção positiva do ego pode ser percebida, pois o ego pode ser visto como uma entidade capaz de organizar suas referências cognitivas livre de pressões e, assim colocar-se em oposição à natureza afirmando sua existência humana ${ }^{45}$. No entanto, tão logo o sujeito passa a intervir dominando a natureza, a racionalidade é ao mesmo tempo refletida para interior do sujeito, intervindo na sua percepção sensorial. Adorno e Horkheimer podem garantir esse processo apenas por igualar à formação do ego a percepção que o sujeito tem da natureza. Assim eles podem conceber o processo de objetivação da natureza com o processo simultâneo e correspondente de enrijecimento da identidade individual: o sujeito não é mais capaz de retrabalhar as impressões que recebe do mundo exterior de uma maneira flexível, mas sim a partir da perspectiva de controle sobre essas impressões. Adorno e Horkheimer equiparam, dessa forma, o processo de formação do ego com o domínio do espaço externo. ${ }^{46}$ E como o auto-controle do ego significa, também, a repressão dos instintos, o trabalho social implica continua alienação dos instintos naturais. Para Honneth, esse tema, presente na maior parte da Dialética do Esclarecimento, permanece pouco desenvolvido e contido em uma estrutura teórica limitada.

A formação da identidade depende unicamente da relação entre o sujeito e o ambiente natural, exclui qualquer necessidade de reconhecimento dos outros indivíduos; os autores não se preocupam em explicar como as formas de supressão dos instintos atuam internamente aos sujeitos, fazendo que toda ação social seja pautada na ação do trabalho social e eliminando formação alternativas de relação com a natureza. Portanto, nem as normas sociais segundo as quais sujeito entra em contato com outros para formar suas demandas sociais e nem autoridade da consciência individual são pontos de referência para a análise. Pelo contrário, o que ganha espaço é a ação de controle, que se refere tanto a ação de sujeito sobre a natureza quanto à ação de sujeito sobre si

\footnotetext{
${ }^{45}$ Honneth,1991.

${ }^{46}$ Honneth,1991.
} 
mesmo $^{47}$. Assim, à medida que os humanos incrementam seu poder sobre a natureza externa, perdem seu poder sobre a sua própria condição humana. Isto porque esta é tratada da mesma maneira que a natureza externa: o processo de dominação progressiva da natureza seria apenas um dos lados do processo histórico geral que se completaria como a alienação e declínio das capacidades humanas. A dominação da natureza e a dominação dos instintos são apresentadas como faces do mesmo processo e a relação do homem com a natureza é uma luta pela dominação sob qualquer ponto de vista. ${ }^{48}$

No entanto, a fim de responder as questões sobre dominação internas à sociedade, particularmente as da sociedade capitalista, Adorno e Horkheimer acrescentam a estrutura da filosofia da História um terceiro elemento teórico, uma teoria da divisão social do trabalho. A análise da dominação intra-societária se dá a partir da distribuição do trabalho produzido acompanhado de um alargamento coletivo dos privilégios desde o início do processo civilizatório capitalista. ${ }^{49}$ À medida que os privilégios são limitados a grupos cada vez menores, o trabalho social passa a ser distinguido entre trabalho intelectual e trabalho manual, em atividades de controle e atividades produtivas. Assim, a formação de uma classe de privilegiados é acompanhada pela formação de uma classe oprimida, que passa a ser responsável pelo trabalho manual. É a partir dessa divisão na apropriação do produto do trabalho social que Adorno e Horkheimer podem imaginar uma sociedade marcada pelo conflito social, no entanto, de acordo com Honneth, continuam a situar a dinâmica do desenvolvimento histórico em uma base que apenas leva em conta, por um lado, o progresso humano e, por outro lado, a realidade natural ${ }^{50}$. Para Honneth a inserção de uma teoria da dominação social no escopo da Dialética do Esclarecimento ocorre de forma abrupta e mecânica e representa a passagem direta e bastante vaga do nível individual para o nível social, das classes em conflito. Adorno e Horkheimer estão presos de maneira tão forte ao conceito de filosofia da História baseado no trabalho que tentam conceber a maneira pela qual a dominação intra-social se desenvolve em relação direta com este modelo, de modo que é necessário que eles entendam o processo de criação e exercício da dominação social a partir de um olhar lançado para a dominação da natureza, que

\footnotetext{
${ }^{47}$ Honneth,1991.

${ }^{48}$ Honneth,1991.

${ }^{49}$ Honneth, 1991.

${ }^{50}$ Honneth, 1991.
} 
baseava seu conceito antropológico de formação da social ${ }^{51}$, acentuando ainda mais o mecanismo desta construção.

Assim, de acordo com Honneth, ao identificarem a dominação com uma forma de opressão ativa de um grupo sobre outro, Adorno e Horkheimer excluem qualquer possibilidade de dominação tomada a partir de um consenso tácito. O que demonstra mais uma vez a incapacidade da Teoria Crítica em conceber a vida social como meio através do qual a dominação se reproduz o que acaba levando os autores a conceber os grupos dominados como vítimas passivas de um sistema de dominação total:

\begin{abstract}
A influência dos temas básicos da filosofia da História no argumento sócio-teórico da Dialética do Esclarecimento é tão forte que Adorno e Horkheimer apenas podem compreender o sujeito socialmente oprimido como uma vítima passiva e sem intenção das mesmas técnicas de dominação que são utilizadas na natureza. Parece que os procedimentos de controle formam indivíduos sem se defrontarem com tentativas de resistência social ou oposição cultural. ${ }^{52}$
\end{abstract}

$\mathrm{Na}$ visão de Honneth, a análise empreendida na Dialética do Esclarecimento é marcada por uma teoria da humanidade pautada pelo crescimento do domínio sobre a natureza, pela dominação de classe e pela repressão dos instintos individuais, exclui a existência de uma esfera de ação social, ou seja, uma teoria em que persiste o "déficit sociológico". Enquanto em "Teoria Tradicional e Teoria Crítica", Horkheimer acreditava no potencial inscrito no desenvolvimento das forças produtivas ao longo do processo de civilização da humanidade, na Dialética do Esclarecimento, este mesmo potencial a ser liberado pelas forças produtivas é visto como imbuído de um potencial destruidor imanente. Na Dialética do Esclarecimento há uma ampliação do conceito de reificação e uma mudança de foco, que se desloca da organização estatal baseada na força direta para as estratégias institucionais de forças indiretas. Ambas as mudanças atestam, segundo Honneth, em última instância, um bloqueio da ação social. Enquanto em Lukcás a reificação é válida apenas para o capitalismo moderno, em

\footnotetext{
${ }^{51}$ Honneth,1991.

52 Honneth, 1991,pág.55.
} 
Adorno e Horkheimer esse conceito assume uma roupagem histórico-filosófica e é entendida como um componente estrutural da organização social humana. As estruturas sociais, tanto econômicas quanto psíquicas e culturais, atuam de modo a impedir ao homem um retorno mimético à natureza. Há uma destruição completa da imaginação adaptativa dos sujeitos, fim da identidade, e consequentemente, de qualquer tipo de ação social. A análise passa a concentrar-se nas estratégias indiretas de dominação.

Essa crítica à situação paradoxal e aporética da crítica radical da razão aproxima Honneth de Habermas, para quem a aporia da Dialética do Esclarecimento surge como uma "contradição performativa". Para Habermas, a definição de razão instrumental toma uma dimensão tão amplificada que inclui também o próprio pensamento filosófico, aquilo que em si mesmo poderia servir como possiblidade emancipatória: “A autocrítica totalizante da razão enreda-se na contradição performativa: não pode convencer a razão centrada no sujeito de natureza autoritária senão recorrendo aos próprios meios dessa razão" 53 . Assim, para Honneth e Habermas a totalização da crítica exercitada por Adorno e Horkheimer, portanto, conduziria a filosofia inevitavelmente a uma direção aporética, a crítica anularia sua pretensão de validade.

Para Habermas, Adorno e Horkheimer estão a escrever a história de uma harmonia desfeita entre o espírito e a natureza, cuja ilustração decorre da descrição que fazem do processo social que constitui a sua filosofia da história ${ }^{54}$. O conceito de verdade, para estes autores, estabelece-se num princípio que denominam de reconciliação universal. Reconciliação que deveria estabelecer-se entre o espírito e a natureza; e a emancipação do ser humano só é conseguida a partir da reabilitação da relação com a natureza. Assim Horkheimer e Adorno preveem uma teoria da mimesis. Nesta teoria defende-se a ideia de que é pela faculdade mimética de imitação, que o homem pode evocar outra atitude na sua relação com o mundo. Com o conceito de mimesis Horkheimer e Adorno tem em vista um novo conceito de razão, que se opõe ao de razão instrumental. Com este novo conceito de razão revalorizam-se as formas de expressão subjetiva do homem, as formas e a produção estética ganham uma dimensão superior de mediação entre o homem e a natureza, pelo que se institui uma relação de pura imitação com o mundo, ao invés daquele tipo de relações de dominação e repressão das forças naturais produzidos pelo modelo positivista. Para Habermas, no

\footnotetext{
${ }^{53}$ Habermas, 2002, p.261.

${ }^{54}$ Habermas,2002,p.655.
} 
entanto, o conceito de mimesis, que deveria dar conta de tudo o que foi destruído pela razão instrumental, se mostra incapaz de gerar uma verdadeira teoria.

Adorno não pode aclarar a capacidade mimética com base em uma oposição abstrata à razão instrumental. As estruturas de uma razão, a que Adorno apenas alude, só estarão acessíveis à análise quando as ideias de conciliação e liberdade puderem ser decifradas como códigos de uma forma utópica de intersubjetividade (seja ela qual for) que possibilite tanto um entendimento entre indivíduos no trato entre si, sem coerções, quanto à identidade de um indivíduo apto a manter entendimento consigo mesmo, também sem coerções - socialização sem repressão ${ }^{55}$.

Assim para evitar as aporias de uma crítica da razão instrumental Habermas propõe uma mudança de paradigma: É preciso passar de uma teoria da ação para uma teoria de sistema; de uma ação cognitiva instrumental para ação comunicativa e, finalmente, de uma racionalidade instrumental para uma racionalidade comunicativa ${ }^{56}$. Antes, no entanto, de nos determos à virada comunicativa empreendida por Habermas, vamos nos ater à crítica de Honneth à Teoria do Poder de Foucault. Se, por uma lado, Habermas é um herdeiro direto da primeira geração da Teoria Crítica, Foucault não possui relações diretas com esta tradição, a não ser no que se refere a seus temas de estudo, e segundo Honneth, a mesma incapacidade de uma analítica do social decorrente da sua teoria. De acordo com Honneth, embora tanto Foucault quanto Habermas tenham avançado sobre as aporias a que chegaram Adorno e Horkheimer, ambos se deparam com limitações de suas próprias teorias no que diz respeito à análise da esfera da ação social. Enquanto "[...] a teoria da sociedade de Foucault representa, em última instância, uma forma de dissolução teórico-sistêmica dos conteúdos desenvolvidos na Dialética do Esclarecimento", Honneth compreende, por outro lado, "[...] a teoria da sociedade de Habermas em termos gerais como uma 'transformação teórico-comunicativa' da Dialética do Esclarecimento" ${ }^{, 57}$.

\footnotetext{
${ }^{55}$ Habermas, 2002, p.673-674.

${ }^{56}$ Habermas, 2002.

${ }^{57}$ Honneth,1991, p.99-100.
} 


\section{FOUCAULT: DISSOLUÇÃO TEÓRICO-SISTÊMICA DA DIALÉTICA DO ESCLARECIMENTO}

No capítulo 6 de Crítica do Poder, intitulado "A teoria da sociedade de Foucault: uma dissolução teórico-sistêmica da Dialética do Esclarecimento"58, Honneth esboça sua crítica ao pensamento de Foucault, mais especificamente ao seu período genealógico. Para ele, Foucault enfrentaria através daquilo que compreende como dissolução teórico-sistêmica da obra de Adorno e Horkheimer, as mesmas dificuldades destes. Isto é, sua teoria seria incapaz de uma análise da ação social, dos modos de integração social. Para Honneth, a teoria de Foucault implicaria uma desvalorização da ordem jurídica face ao processo de intensificação sistêmica do poder e dessa forma, sofreria do mesmo "déficit sociológico" que marca a primeira geração crítica. A investigação de Honneth se concentra na passagem da arqueologia do saber à genealogia do poder, situando como momento de transição expressões nas qual Foucault sinaliza estar se referindo não mais ao grande modelo da língua e dos signos, mas sim ao da guerra e da batalha, localizando, dessa maneira, as relações de poder e não de sentido. É importante destacar que Honneth não leva em consideração nas suas análises outra modificação ocorrida no interior do pensamento foucaultiano, aquela empreendida a partir de 1978, em direção à estética da existência e à ontologia histórica de nós mesmos ${ }^{59}$, o que parece limitar seu diagnóstico sobre o pensamento do filósofo francês. Dado o escopo do tema desenvolvido nesta dissertação não nos aprofundaremos nessa discussão, mas apenas em esclarecer a crítica de Honneth ao período genealógico.

Com seu método da arqueologia do saber Foucault pretende superar uma análise histórica marcada pela filosofia do sujeito, ou seja, superar o modelo em que a produção de entendimento do mundo é atribuída aos indivíduos. A teoria social de Foucault assume as características de uma "teoria do inconsciente cultural", no qual o sujeito social é entendido como resultado das mesmas normas e cognições que codificam a cultural. Para livrar-se da tradição da filosofia da reflexão, na qual a ação

\footnotetext{
${ }^{58}$ Honneth,1991, p. 176.

${ }^{59}$ Após 1976, ano de publicação do primeiro volume da História da sexualidade: a vontade de saber, Foucault opera um redimensionamento interno no seu pensamento, em especial no que se refere à posição central que a dimensão da subjetividade passa a ocupar na relação entre saber-poder. A subjetividade do homem não é mais interpretada como mero campo de manipulação para as técnicas de poder, senão como elemento independente e constitutivo em uma estrutura de poder respectiva. Seja como for, em suas principais obras sobre a teoria do poder os indivíduos não representam senão seres formáveis e manipuláveis sem oferecer resistência.
} 
reflexiva do sujeito forma sua individualidade, a passagem do século XVIII para o XIX, período em que, segundo ele, tem lugar à formação da ideia de homem moderno, ou seja, período em que o homem passa a ser concebido tanto como sujeito quanto como objeto do conhecimento, passa ser referência fundamental do seu estudo.

Foucault reconhece o erro cometido por uma filosofia da História quando esta transfere a ideia de uma " função constitutiva do sujeito" para os processos sociais. A fim de evitar as armadilhas desta concepção filosófica, ele deve manter os conceitos básicos de sua nova concepção livres de máculas da filosofia da reflexão tradicional. Mas ao invés de questionar a singularidade do sujeito histórico, a quem as realizações constitutivas são atribuídas, e substitui-la pelo modelo mais convincente de uma pluralidade de atores, Foucault adota a perspectiva oposta de uma eliminação do conceito de sujeito em geral. Ele não questiona o caráter monológico da filosofia da reflexão, mas, antes, rejeita seu modelo fundamental de pensamento de forma geral. ${ }^{60}$

Para Foucault uma filosofia da História consciente, ou seja, centrada na filosofia do sujeito, perde de vista os espaços "micro-históricos"61, reduz o movimento da história a atividade consciente do sujeito ou grupo social. Para a superação desde modelo, ele propõe a metodologia de uma arqueologia histórica. A constituição do mundo objetivo passa a ser entendida como produto de um sistema não intencional de sinais, no qual a estrutura da ordem linguística é quem determina a experiência linguística:

\footnotetext{
$\mathrm{Na}$ verdade ele tenta ir além do horizonte de um modelo de pensamento em que a conquista cognitiva da produção de seu próprio mundo de experiências é atribuída a indivíduos humanos(...) ele o desloca completamente com um modelo oposto de pensamento em que a função quase transcendental de constituição do mundo não é atribuída a ações monológicas de um ego às realizações interpretativas

${ }^{60}$ Honneth, 1991, pág. 119-120.

61 Na introdução da Arqueologia do saber, Foucault argumenta: " já há bastante tempo que os historiadores demarcam, descrevem e analisam estruturas, sem jamais se terem perguntado se não deixavam escapar a viva, frágil e fremente 'história'”, 1972, pág.20.
} 
intersubjetivas dos sujeitos, mas sim a um sistema não intencional de sinais. A estrutura de uma ordem neutra de sinais determina a forma subjetivamente necessária da experiência possível ${ }^{62}$.

De acordo com essa metodologia de uma arqueologia da História, construída de fora, Foucault visa capturar o modo pelo qual não o sujeito singular, mas a organização social propriamente dita e os meios pelos quais esta se dá ocorrem. A formação do discurso aparece como um processo por meio do qual os agentes capazes de se apropriarem dele obtêm certo nível de domínio sobre as formas mesmas de organização social, isto porque as sentenças da ordem linguística passam a ser concebidas como sendo de um patamar superior ao da ação humana. O discurso aparece, segundo Honneth, como um meio externo de dominação a ser apropriado pelos sujeitos, ou seja, a apropriação do discurso se faz, independente da forma, quando alguns dos agentes sociais conseguem utilizá-lo em favor próprio. Para Honneth, no entanto, o projeto foucaultiano de uma arqueologia do saber é cercado por paradoxos. Segundo ele Foucault não é claro ao apresentar a definição do conceito de discurso, dando margem a duas possibilidades interpretativas. Por um lado, o discurso aparece como um evento linguístico previamente existente que pode servir como meio de dominação; por outro o discurso é visto como o produto de uma atividade dirigida para a dominação. Para Honneth tal paradoxo não está na inconsistência das respostas, mas nas próprias técnicas e proposições metodológicas de Foucault, levando-o a abandonar o programa de uma teoria do conhecimento em favor de uma análise daquela caracterização funcional do discurso como meio de dominação ${ }^{63}$.

Com essa mudança teórica, Foucault traz para primeiro plano as condições institucionais de produção do conhecimento e, consequentemente, o contexto das estruturas sociais. A organização da sociedade é entendida como resultado do conflito pela apropriação do discurso, ou seja, como resultado da constelação social de estratégias utilizadas pelos grupos em busca de poder e desejo a partir da apropriação do discurso. Essa formulação permite a Foucault entender os procedimentos institucionais para o controle do conhecimento como tecnologias de controle social e, segundo

\footnotetext{
${ }^{62}$ Honneth, 1991, pág. 125.

${ }^{63}$ Honneth,1991.
} 
Honneth, representam um ganho para a proposta foucaultiana no sentido de uma teoria social.

O discurso passa a ser concebido como um sistema de conhecimento social que cumpre a função de aumentar o poder daqueles que detém sua posse. Essa nova concepção representa, portanto, o abandono do seu projeto inicial de uma arqueologia das ciências modernas em favor de uma teoria social do poder e da formação do conhecimento:

\begin{abstract}
No lugar de uma análise que busca investigar os sistemas culturais de conhecimento a partir da relação interna entre componentes linguísticos significantes, uma análise sócio-teórica que investiga as relações externas(ou seja, funcionais ou causais) entre os constituintes empíricos do sistema social, entre a formação do conhecimento e as relações de poder, pode aparecer" ${ }^{64}$
\end{abstract}

Como lembra Honneth, para Foucault o poder é resultado das relações sociais. Ele não deve ser pensado como uma forma estática adquirida pelos sujeitos ou estabilizada nas instituições sociais, mas como produto instável de conflitos estratégicos entre sujeitos. Para Honneth, a teoria do poder de Foucault pode ser classificada como modelo teórico de ação social. O processo de formação, exercício e manutenção do poder resulta da ação estratégica entre atores sociais. ${ }^{65} \mathrm{O}$ poder social está relacionado com a capacidade dos sujeitos de fazer a interação funcionar a seu favor. A sociedade é compreendida como resultado de um estado de luta não finalizado, e a dimensão da ação social recebe o status específico de uma intersubjetividade estratégica do conflito.

No entanto, de acordo com Honneth, o conceito de ação social foucaultiano permanece indefinido. Foucault não esclarece se as lutas são levadas a cabo por atores individuais ou coletivos, nem se a causa das lutas é o interesse incompatível entre os indivíduos ou se esta incompatibilidade se deve a certas condições históricas. Foucault está interessado em explicar como uma ordem de dominação surge dos conflitos estratégicos entre os atores, ou seja, nas estruturas complexas de poder decorrentes dos conflitos entres atores sociais e não na forma elementar de conflito. Assim, portanto,

\footnotetext{
64 Honneth, 1991, pág. 152. Nesta passagem da teoria do conhecimento para teoria do poder, diz Honneth, os temas de Foucault enfim aproximam-se daqueles da Teoria Crítica.

${ }^{65}$ Ver Honneth,1991, pág.153-155.
} 
segundo ele, a dominação não pode ser centralizada em um único meio, já que surge de uma infinidade de atos e não se formaliza em um veículo de dominação, mas em uma estratégia, de forma que sua existência só é possível na regulação bem sucedida de situações de conflito. ${ }^{66}$

Para Foucault as situações estabelecidas de poder e dominação se conectam como uma rede sem centro definido. Uma vez que o poder se desenvolve horizontalmente, um sistema de poder é compreendido como a ligação, em rede, de sistemas particulares de poder, cuja finalidade é alcançar um objetivo comum sobre um contexto de vida social. A sobrevida histórica de um sistema de poder depende do sucesso das ligações de poder em situações semelhantes de conflito, ou seja, ao se reproduzir em outras situações de conflito a rede de poder ganha continuidade e a ordem de poder é temporariamente estabilizada na forma de sistema. Assim a estrutura de poder social deve ser entendida a partir das atividades descentralizadas dos diversos atores envolvidos nas diferentes situações de conflito, e não de um único aparato capaz de influenciar comportamentos e consciências. Essa noção de poder que não se reduz à influência do Estado é chamada por Foucault de "microfísica do poder" e significa que a formação do poder pode ser referida às interações cotidianas, especificamente ao corpo. ${ }^{67} \mathrm{O}$ conceito de poder é entendido como um estado momentâneo dos arranjos sociais, que está constantemente exposto a um processo de testes por meio dos conflitos sociais $^{68}$.

No entanto, segundo Honneth, esse modelo de interação estratégica exclui qualquer consenso normativo como meio de estabilização temporária de um sistema de poder, o que leva Foucault a investigar quais os meios para o exercício do poder utilizados nas sociedades modernas, uma vez que estas não podem se valer apenas de instrumentos violentos e medidas ideológicas. Foucault propõe uma noção positiva de poder, cujo seu exercício se realizaria através da normalização dos comportamentos com vistas a responderem aos interesses da dominação social, no caso do capitalismo, a produção material. Há na obra de Foucault, diz Honneth, a primazia da análise da conduta do corpo humano em detrimento das atividades morais e cognitivas. Isto se

\footnotetext{
${ }^{66}$ Honneth,1991.

${ }^{67}$ Foucault chama esta técnica de poder que atua sobre o corpo de "saber do corpo" e a classifica como uma tecnologia política do corpo, que não pode ser remetida a um centro único, mas que atua de forma difusa e multiforme: "Trata-se de alguma maneira de uma microfísica do poder posta em jogo pelos aparelhos e instituições, mas cujo campo de validade se coloca de algum modo entre esses grandes funcionamentos e os próprios corpos com sua materialidade e suas forças" Foucualt, 2007, pág. 26.

${ }^{68}$ Honneth, 1991.
} 
deve ao fato de que sua teoria do poder social privilegia antes a execução do que os seus efeitos. Foucault tem por interesse primário a história da dominação e sua atuação sobre objetos de dominação (o corpo, a norma e o conhecimento), isto é, é a formação das normas e não o seu conteúdo o que interessa a Foucault. Para ele as modernas técnicas de controle não apenas controlam a conduta corporal, mas as criam por meio de processos de normalização. A disciplina corporal, dessa forma, se transforma em automatismo cego de atos rotineiros tendo em vista o trabalho produtivo. A produção de conhecimento científico pelas instituições é regida por interesses estratégicos com vistas à aquisição de poder e dominação, e por isso constitui processo cumulativo de aprendizado sobre as técnicas de dominação. Assim a evolução social não é mais compreendida como decorrente da ação de atores coletivos ou individuais, mas das instituições que direcionam aquele acúmulo de conhecimento para o estabelecimento de regras sociais. Com isso, segundo Honneth, a teoria de Foucault abandona qualquer resquício de teoria da ação:

O quadro de referência para o conceito de poder teria, portanto, secretamente mudado de uma teoria da ação para uma análise das instituições. Mas então o diagnóstico teórico das técnicas de poder não fixa realmente o problema na agenda, mas, antes, simplesmente o afasta. Enquanto o conceito de poder deveria ter sido desenvolvido a partir da intersubjetividade prática dos conflitos sociais, sem ter sido capaz de explicar suficientemente o processo de estabilização das posições de poder social, a análise das técnicas de poder inesperadamente se vale da ideia de instituições de exercício de poder sem ter que se referir aos seus processos de estabilização". ${ }^{69}$

Para Honneth, a teoria das instituições com que Foucault passa a trabalhar, sofre do mesmo "déficit sociológico" que havia identificado nas obras de Horkheimer e Adorno. Isto porque a questão da estabilização das posições de poder desaparece nesta teoria. Para Honneth, a fundamentação de uma teoria social exclusivamente na ideia de conflito leva Foucault a interpretar a estabilização de posições de poder de forma reduzida a partir da ideia de força unilateral. Segundo Honneth, a estabilização de

\footnotetext{
${ }^{69}$ Honneth, 1991, pág. 173.
} 
poder pressupõe a interrupção dos conflitos seja por meio de um consenso normativo, de um compromisso pragmático ou mesmo do uso de força. As duas primeiras hipóteses de estabilização pressupõe uma relação bilateral que levaria uma interrupção dos conflitos estratégicos, algo que a teoria de Foucault não comporta, restando-lhe a possibilidade teórica da terceira opção, ou seja, a estabilização de posições de poder é interpretado como resultado do uso constante de força. As instituições aparecem, dessa forma, como uma via unilateral de força responsável pela ordem social. Para Honneth a determinação sócio-teórica das modernas técnicas de dominação além de reducionista, revela a contradição entre o modelo básico de ação social, o conflito estratégico, e a teoria social subsequente, do poder institucional baseada na força.

Para Honneth, ao dispor do exemplo do sistema prisional como a ligação institucional entre diversos aparelhos de controle, Foucault já deixa entrever a inversão teórica da ação em um modelo de instituições totais ${ }^{70}$. Seguindo o caminho anteriormente desenvolvido da teoria do poder, Foucault em "Vigiar e Punir" que o desenvolvimento da punição é antes uma contribuição institucional para a construção do moderno sistema de poder social, por meio de um controle ainda maior sobre o corpo do que aquele exercido pela pena violenta. Assim a estrutura conceitual foucaultiana não é mais a gênese abstrata do conceito de subjetividade, mas o surgimento prático da moderna representação dos sujeitos dentro do contexto de estratégias de poder social. O caminho seguido por Foucault evidencia uma concepção histórica guiada pela perspectiva de crescimento sistêmico do poder, como se não houvesse influência dos processos subjetivos, mas apenas a necessidade de emergência de um novo sistema capaz de lidar com novas condições históricas. Seu modelo é caracterizado, dessa forma, antes por um crescimento de poder social do que uma analítica da ordem social:

O que fica no centro deste modelo não é uma ordem social dada, mas um processo de crescimento do poder social, do que se assume que este processo cumpre funções em conexão com problemas invariantes de referência. Se Foucault segue tal procedimento metodológico, ele deve tentar observar todos os processos sociais de uma perspectiva funcionalista, não da manutenção, mas sim do aumento do poder; em

\footnotetext{
${ }^{70}$ Ver Honneth,1991, pág.175-179. A passagem do conceito de arqueologia para o de genealogia.

${ }^{71}$ Foucault, 2007.
} 
outras palavras, do ponto de vista objetivo direto de um controle máximo sobre os processos de vida social. ${ }^{72}$

Honneth, ao criticar a ausência de um espaço de análise social nos modelos críticos de outros autores pretende, na verdade, expor a falta de uma teoria ao nível individual, ou microfísico, no caso de Foucault, que se relacione com os processos sociais mais amplos. Enquanto Horkeneimer e Adorno realizam uma mediação direta entre o nível psíquico e as estruturas socioeconômicas, o que impedira a ambos de perceber a existência de um tipo de ação diferente do conformismo; Foucault, que antes do modelo de dominação sistêmica de "Vigiar e Punir" conseguira desenvolver uma teoria da ação social, ao optar por uma análise da dominação ao nível das estruturas institucionais da sociedade, afasta-lhe da possibilidade de relacionar ação e estrutura justamente na medida em que a formação de consensos, normas e valores não se situam na primeira destas esferas, onde se encontram os indivíduos, mas na última, onde as instituições cumprem este papel.

Para Honneth, Foucault escolhe desenvolver uma teoria da dominação ao invés de uma teoria focada na formação do indivíduo mesmo, onde se poderia observar um espaço de evolução moral das relações social. Assim para ele, a estrutura metodológica de suas obras tardias, diz Honneth, é marcada por uma teoria sistêmica em que a organização social é caracterizada como decorrente da estruturação do poder social segundo a tendência das instituições de aumentar os meios para exercer o poder através de um "processo trans-subjetivo de aprendizado",73. Isso explica, para Honneth, porque Foucault dá tão pouca atenção à organização econômica das sociedades que analisa, esta é vista apenas como uma decorrência do sistema de poder social estruturado a partir das instituições; também fica claro porque, ele, apesar de apresentar sua teoria como uma teoria da ação estratégica, oferece pouca atenção ao conflito social:

Tão $\operatorname{logo}$ a evolução social é concebida como um processo de aumento do poder social realizado de acordo com a lógica de adaptações periódicas ao meio, como é obviamente o caso nas análises históricas de Foucault, segue-se que as classes que dominam a cada momento dado são vistas como meros portadores de processos sistêmicos, isto é, como uma quantidade que, em princípio, pode ser

\footnotetext{
72 Honnth, 1991, pág.184.

${ }^{73}$ Honneth,1991.
} 
ignorada. Mais que formadores da fase prática para a institucionalização das formas de dominação, os conflitos sociais são o plano cotidiano sobre o qual os processos sistêmicos pavimentam o caminho. $" 74$

Foucault ainda cai vítima, segundo Honneth, de uma concepção mecanicista quanto às formas de comportamento:

Da perspectiva de uma teoria dos sistemas que vê os processos sociais como processos sistêmicos de aumento de poder, os próprios modos de conduta humana, usam especialmente expressões corporais, são apenas materiais a serem enformados por estratégias de poder operativas em um determinado momento. Por contraste, tivesse Foucault seguido consistentemente os traços de seu modelo original da ação, no qual as formas existentes de dominação social eram vistas como produtos de conflitos sociais e não meios resultantes de processos sistêmicos de adaptação, ele teria sido impedido de favorecer conceitualmente os atores sociais com motivos que, em primeiro lugar, tornam possível produzir revoluções políticas e, assim, conflitos sociais em geral ${ }^{75}$.

Ao contrário do que propunha em suas pesquisas iniciais, Foucault não mais vê as normas legais e as ideias morais como a superestrutura variável de um núcleo histórico invariável, mas a superestrutura cultural de um processo sistêmico de aumento do poder, de modo que o modelo de uma teoria da ação se transforma em modelo de teoria dos sistemas. Para Honneth, isto caracteriza o que ele chama de "teoria dos sistemas unilateralmente restrita a processos de controle" (systems theory one-sidedly restricted to steering process) $)^{76}$.

Honneth pode concluir, dessa maneira, em paralelo a sua análise de Adorno no que se refere à dominação nas sociedades modernas, que Foucault acaba por fornecer a imagem de uma estrutura unidimensional de controle em que o aperfeiçoamento dos

\footnotetext{
${ }^{74}$ Honneth, 1991, pág. 195.

75 Honneth, 1991,pag, 195.

${ }^{76}$ Honneth, 1991, p. 195.
} 
meios de dominação se faz sob o disfarce de emancipação moral. Ambos levados a compreender o desenvolvimento da atividade científica como conhecimento voltado para dominação, isto por que entendem o processo de racionalização técnica como potencializador do processo de dominação, processo esse que culmina na organização totalitária das sociedades desenvolvidas, ou seja, como sociedades unidimensionais cuja reprodução remete a uma ordem administrativa aperfeiçoada pela técnica racionalizada. A teoria de Foucault exclui, dessa forma, a possibilidade de ação social:

De acordo com a visão comum de Adorno e Foucault, nem os grupos sociais e nem as convicções normativas e orientações culturais dos sujeitos socializados têm um papel na integração social das sociedades de capitalismo tardio. É somente o trabalho de dirigir realizações de uma organização sistêmica independente. Adorno vê este processo de controlar realizações como produzido pela atividade planejada e manipuladora de uma administração centralizada. Foucault, em contraste, acredita que as realizações necessárias seguradas pelos procedimentos de controle e disciplina são produzidas por organizações institucionalmente legadas, como a escola, a prisão e a fábrica. ${ }^{77}$

Para Honneth, ambos os autores não estariam atentos ao fato de que os grupos sociais, através de suas orientações normativas e convicções culturais participam do exercício de dominação, e isto os leva a basear suas teorias sociais em um modelo coercitivo de ordem social. Para Honneth, Foucault, após uma promissora incursão na teoria da ação com sua noção de um conflito microfísico, apresenta uma teoria do poder que representa uma solução sistêmica para os problemas levantados pela Dialética do Esclarecimento, cujo resultado é apenas a descrição objetiva do aumento do poder social. Ambas as formas, contudo, diz Honneth, são inapropriadas para analisar as formas de integração nas sociedades do capitalismo tardio.

\footnotetext{
${ }^{77}$ Honneth, 1991, pág.199.
} 


\title{
4. HABERMAS: A "VIRADA COMUNICATIVA" E FICÇÃO DE UMA SOCIEDADE DIVIDIDA EM INTERAÇÃO E TRABALHO.
}

Para Habermas o fracasso da Teoria Crítica da Escola de Frankfurt se deve a certas aporias herdadas da filosofia da consciência.

\begin{abstract}
A filosofia que se retrai à "memoração da natureza", ou seja, a um ponto anterior às linhas do pensamento discursivo, precisa pagar pela força despertadora advinda do exercício de si mesma o preço de desviar-se a meta do conhecimento teórico- e, portanto daquele programa do "materialismo interdisciplinar" [...] o programa da teoria crítica em sua fase inicial fracassou não por este ou aquele acaso, mas por causa do esgotamento do paradigma da filosofia da consciência. Demostrarei que uma mudança de paradigma em direção à teoria da comunicação permite o retorno a um empreendimento que, a seu tempo, viu-se interrompido pela crítica da razão instrumental; essa mudança de paradigma pode consentir na retomada de tarefas de uma teoria social crítica que ficaram abandonadas. ${ }^{78}$
\end{abstract}

É através do conceito de racionalidade comunicativo que Habermas pertente escapar às aporias de uma crítica da razão instrumental que Horkheimer e Adorno não conseguiram escapar. O conceito de mimesis, que deveria dar conta de tudo o que foi destruído pela razão instrumental, mostra-se incapaz de gerar uma verdadeira teoria. Habermas empreende uma virada comunicativa na teoria crítica com seu conceito de ação comunicativa, o qual o possibilita entender as estruturas da dominação social como resultado de processos de entendimento comunicativo baseados em relações intersubjetivas. No entanto, segundo Honneth, ele desenvolve a ideia da comunicação intersubjetiva em duas concepções diferentes de teoria da sociedade: uma, no sentido de uma lógica da racionalização (em conexão com crítica tecnocracia), outra, no sentido de uma dinâmica dos conflitos sociais (em conexão com a crítica a Marx). Para Honneth, o fato de ele ter aprofundado apenas o primeiro modelo sugere que ao invés de uma teoria do conflito social Habermas desenvolve uma teoria em que o conflito ocorre entre dois tipos de lógica racional entendidos de maneira reificada o que, segundo ele, leva Habermas a abandonar o potencial da teoria comunicativa.

\footnotetext{
78 Habermas, 2012, p.664-665.
} 
O primeiro modelo surge em conexão com a crítica que Habermas faz à tecnocracia $^{79}$. Habermas se opõe à ideologia positivista que vê a racionalização e o aumento da técnica como um processo único e positivo, sem atentar para outras esferas da vida humana. Para se opor a essa ideologia, Habermas lança mão da noção teóricocomunicativa como uma teoria do desenvolvimento social ${ }^{80}$. A distinção entre “ trabalho" e "interação" aparece como uma distinção entre dois processos de racionalização necessários para o estabelecimento das sociedades humanas. Habermas, entretanto, expande esta distinção a ponto de observar dois tipos de subsistemas sociais. Ele chama de estrutura institucional da sociedade os espaços em que, mediados por regras de conduta morais, a vida socio-cultural das sociedades se desenvolve; susbistemas, os espaços orientados pela ação racioal, como a economia e o aparato político estatal ${ }^{81}$. O mundo da vida sócio-cultural é entendido por Habermas, a partir dessa definição, de uma maneira teórico-intitucional, para a qual as normas sociais(institucionais) são equivalentes ao sistema de compreensão social que perpassa a sociedade. Estas normas, contudo, não são fruto de tradições culturais estabelecidas, mas de um processo de interação simbolicamente mediado. Habermas caracteriza este espaço com o conceito de sistema. Para Honneth, esta atribuição lhe parece um pouco preciptada, visto que o processo de produção e observância de normas possui status bastante frágil. Em contraste com esta esfera, Habermas chama de subsistema, o espaço de ação racional no aqual os objetivos são orientados por regras de maximização dos objetivos racionais. Este espaço não normativo se refere às esferas de ação social cuja organização é regida pelas regras de ação racional-finalista, mas que ainda são consideradas subsistemas porque seus limites e funcionamentos são estabelecidos pelo sistema de normas institucionalizadas. Para Habermas esse conceito de subsistema também é questionável. Para ele a transposição de tais determinações teóricas para a prática social requer, além do recurso à maximização da ação racional, a aplicação de pontos de vista normatizadores ou políticos que permitam sua realização. Para Honneth, o conceito de subsistema assumido por Habermas, põe em cheque os pressupostos assumidos pelo próprio Habermas na construção de seu modelo teórico-comunicativo. A idéia de uma práxis social que se desenvolve dentro de uma estrutura onde se faz

\footnotetext{
${ }^{79}$ Habermas, 1968a.

${ }^{80}$ Honneth, 1991.

${ }^{81}$ Honneth, 1991. Ver também Habermas, 1968b.
} 
necessária a comunicação entre os indivíduos não é compatível com a existência de subsistemas que parecem prescindir a essa regra. Segundo Honneth, Habermas

se permite ser levado a uma concretização falsamente colocada pela plausibilidade de suas próprias distinções quanto à teoria da ação. As diferenças estruturais que ele havia descrito conceitualmente entre ação comunicativa e ação-racional-com-respeito-a-fins são repetidas agora ao nível do processo social de reprodução na medida em que ele distingue entre esferas sociais de acordo com as quais dos dois tipos de ação predomina em cada uma delas. Assim, mesmo sem intenção, ele permite à distinção analítica transformar-se em uma diferença entre os domínios empíricos dos fenômenos a ponto de surgir à ficção de uma sociedade dividida em domínios de ação comunicativamente organizados ou raciona-finalisticamente organizados. Ao invés de se questionar sobre a forma organizacional específica do processo de comunicação que contribui para o domínio propositivo racional das tarefas respectivamente propostas, aparece a imagem de um domínio de tarefas que são, em um momento, racional-propositivas e, no outro, comunicativas $^{82}$.

Para Honneth, portanto, ao passar do modelo teórico-comunicativo para um modelo teórico-sistêmico, Habermas sobrepõe a distinção analítica deste último às bases sociais que fundamentavam sua teoria e passa a lidar com dois processos recíprocos de racionalização. Cada esfera de ação social é caracterizada por um processo próprio de racionalização, ou seja, cada esfera constitui um espaço relacionado à produção de um tipo específico de construção do conhecimento e, assim, as duas esferas de ação social são distinguidas também quanto ao seu tipo de racionalidade. No entando, para Honneth, a aplicação do conceito de racionalização, que pode ser feita de maneira direta para a esfera da ação racional-finalista, enfrentaria dificuldades quando relacionada com a esfera das normas sociais, pois seu critério de validade seria uma organização em que a ação comunicativa pudesse ser livre dos efeitos da dominação social. Com vistas a resolver esse problema, Habermas passa a conceber o processo de

\footnotetext{
82 Honneth, 1991, pág. 255-6.
} 
evolução da espécie a partir da relação recíproca entre esses dois processos de racionalização, procura entender não apenas o processo de racionalização das esferas não-normativas, mas também a racionalização do processo comunicativo. Este modelo passa a orientar a teoria habermasiana: “O que fora revelado na crítica do positivismo ao nível da lógica da ciência como uma forma suprimida de racionalidade humana é exposto como um elemento interno, dinâmico do processo histórico" 83

A partir desse modelo Habermas interpreta a passagem das sociedades tradicionais para as sociedades modernas, como um processo no qual as esferas simbolicamente orientadas passaram a ser submetidas à racionalidade finalista da outra esfera. Para Honneth, no entanto, a aplicação desse modelo para descrever a fomação do capitalismo liberal acarreta uma série de problemas ${ }^{84}$ :

não é tanto o elemento teórico em particular, ou o alto grau de abstração enquanto tal, que é questionável na descrição de Habermas dos princípios estruturais, mas o modelo geral com o qual a totalidade de uma sociedade intersubjetivamente alcançada torna-se cortada em uma parte comunicativa e outra racional-propositiva de modo que a emergência do capitalismo deve ser compreendida como uma invasão dos princípios racionais-propositivos em um mundo da vida previamente organizado a partir da comunicação ${ }^{85}$

Para Honneth, a tendência identificada por Habermas como dominante em sua época, ou seja, a autonomização da tecnologia relega a dimensão da ação social e das estratégias de formação de poder, inclusive dentro do mundo da vida, a um plano secundário, uma vez que a estrutura institucional, pensada como uma construção comunicativa, sofre com o poder e a dominação não por parte de grupos privilegiados que controlam estes espaços, mas sim devido à pressão de adaptação que a esfera racional exerce sobre esta esfera normativa, de modo que não é o conflito ou o entendimento social que impulsionam a transformação histórica, mas a diferença entre dois tipos de racionalidade:

\footnotetext{
${ }^{83}$ Honneth, 1991, pág. 261.

${ }^{84}$ Ver pagina 262

${ }^{85}$ Honneth, 1991, pág. 262-3.
} 
este conflito básico que distingue a evolução social não enfatiza internamente o processo de entendimento social como uma oposição entre grupos sociais ou classes, mas é estabelecido no terreno de um campo de oposição entre as esferas de ação racional-propositiva e comunicativamente organizadas. O movimento que historicamente desvela este conflito não é mediado pelas lutas de grupos sociais ou classes, mas surge como um processo de racionalização que se estende sobre as classes e permite que a ação racional-propositiva inicialmente emirja da estrutura de normas intersubjetivamente válidas e, finalmente, como sistemas reajam destrutivamente sobre as relações de interação moralmente desenvolvidas ${ }^{86}$.

Habermas identifica duas formas de racionalização que conduzem à crise de legitimação do capitalismo. A primeira delas se refere à racionalização da infraestrutura social, esta ocorre de baixo para cima, de modo que "as contexturas tradicionais ficam cada vez mais submetidas às condições de racionalidade instrumental" ${ }^{87}$. Esta racionalização toma conta da organização mesma da vida social. A outra tendência é a da racionalização de cima para baixo, por meio da qual o mito é privatizado e personalizado, enquanto na esfera pública passa a vigorar uma nova ideologia antimitológica sob a forma de ciência. De acordo com Honneth, ambas as tendências observadas por Habermas, constituem uma crescente influência da teoria dos sistemas em detrimento da teoria da ação social, isto porque, nos dois movimentos, é o crescimento dos imperativos sistêmicos que determina a tendência diagnosticada. Para Honneth, portanto, não há uma concepção interna entre os dois processos de racionalização. Os processos de comunicação não interferem no espaço de fomação e organização das ações racional-finalistas, ao passo que estas apenas atuam destrutivamente sobre aquelas. Isto é, trabalho e interação não são vistos como entrelaçados na história da espécie.

\footnotetext{
${ }^{86}$ Honnth, 1991, pág. 268.

${ }^{87}$ Habermas, 1968, pag. 326.
} 
Habermas é impedido de introduzir em um nível conceituamente básico outra concepção da interdependência social das duas foram de ação(...) por reificar a distinção entre as duas esferas de ação e, ao nível do diagnóstico do tempo, por uma conexão não pretendida com a tese da tecnocracia ${ }^{88}$

Segundo Honneth, no entanto, é possível encontrar um modelo alternativo de teoria em outros textos de Habermas no qual a interação social também ocorreria como um conflito pela forma da organização social. Ao contrário do modelo anterior, no qual o processo histórico deriva de um mecanismo evolutivo supra-individual como racionalização da interação comunicativa, neste segundo modelo a evolução social da espécie é vista como consequência dos conflitos sociais e dessa forma pode ser referida a partir de uma dinâmica moral presente neste conflito. Esse modelo alternativo implica, portanto, uma mudança na estrutura sócio-teórica da teoria de Habermas. A separação entre as esferas de interesse racional e comunicativo é substituida pela imagem de uma sociedade separada em grupos sociais com interesses conflituosos (as classes sociais). A partir dessa perspectiva a organização institucional e da práxis social de forma geral passa a ser interpretada como produto, temporário, do processo de interação entre diferentes grupos nas formas de entendimento ou conflito. Assim, as formas institucionais em que as relações de trabalho e administração política são organizadas também aparecem como fruto de consensos morais e interações comunicativas. Esse modelo, portanto, contradiz o modelo social da crítica da tecnocracia, uma vez que o subsistema da ação racional-finalista também seria marcado por relações comunicativas. Mas garante, de acordo com Honneth, o preenchimento da lacuna que segundo ele marca os modelos anteriores de explicação da dominação nas sociedades contemporâneas. O conceito de ação social presente nessa teoria entendido como a formação de consensos e normas através do conflito garantiria a relação entre as motivações individuais e o processo histórico de mudança social. Esta parece ser a relação que Honneth pretende descobrir nesta esfera ao relacioná-la com a idéia, que ele indentificara em Horkheimer, de uma zona moral pré-teórica.

\footnotetext{
${ }^{88}$ Honneth, 1991, pág. 268.
} 
Com a análise da história baseada no conflito de classes Habermas precisa estender a capacidade comunicativa também a grupos coletivos, o que mais uma vez entra em choque com o admitido pela sua teoria. Habermas assume primariamente que somente os indivíduos se colocam em interação e são capazes de expressar seus interesses, no entanto com o conceito de conflito de classe esta capacidade deve também ser estendida a grupos coletivos, ou seja, ao lutar pela legitimidade de normas morais, as classes também demostram capacidade de atuação social, bem como capacidade de compartilhar valores e orientações políticas. Segundo Honneth, no entanto, Habermas realiza essa passagem apresentando as classees de forma homogênea e passível da mesma carcterização oferecida aos indivíduos. Ele atribui isso, ao fato da teoria habermasiana ainda se encontrar presa a uma estrutura teórica da filosofia da história, o que o impede de perceber que as lutas poderiam ser levadas a cabo por atores coletivos em busca de reconhecimento. Esse modelo de interação intersubjetiva concebido como responsável pela formação de identidade dos grupos socias, diz Honneth, excluiria a necessidade conceitual da filosoifa da História, pois os atores sociais não precisariam ser entendidos como macro-sujeitos:

Os atores coletivos que se relacionam coletivamente uns com os outros não precisam ser entendidos como macro-sujeitos; eles podem ser entendidos como grupos sociais cuja identidade coletiva em si mesma é um produto sempre frágil e ameaçado do processo de socialização realizado entre os indivíduos ${ }^{89}$.

Segundo Honneth, a opção de Habermas pelo primeiro modelo, da análise da autonomização da tecnologia, teria o impedido de desenvolver uma teoria sobre a capacidade de grupos sociais de realizarem uma interação pautada pela busca de reconhecimento. O modelo do conflito social, diz Honneth, não foi além de um esboço, uma vez que o próprio Habermas no final de sua discussão sobre a tecnocracia aponta para o fato de que as lutas realizadas em função de "subprivilégios sociais" por parte de alguns grupos não são capazes de revolucionar um sistema social que produz a latência do conflito direto entre as classe, uma vez que " os grupos subprivilegiados não são de modo algum classes sociais; eles nunca representam, nem mesmo potenciamente, a

\footnotetext{
${ }^{89}$ Honneth, 1991, pág 275.
} 
massa da população"90. Para Honneth, as consequências do possível segundo modelo presente na teoria habermasiana são negados justamente pelo modelo que Habermas opta por aprofundar. Para Honneth, no entanto, o segundo modelo pode ser encontrado apenas a partir de uma reconstrução indireta que parta da própria teoria do reconhecimento, enquanto o primeiro modelo teórico, da crítica da tecnocracia, é o que orienta a formação posterior da teoria habermasiana. Portanto, a construção de um modelo crítico que superasse estes problemas por meio de uma análise efetivamente pautada no social é a tarefa que Honneth se propõe a seguir, em Luta por Reconhecimento ${ }^{91}$.

É possível depreender das análises realizadas por Honneth em Crítica do Poder que o problema central enfrentado pela Teoria Crítica é o desenvolvimento de um conceito de "social" que "integre todo espectro da ação cultural cotidiana", cada um de nós é tão completamente incorporado. Embora Honneth atribua à tradição crítica um "déficit sociológico", ele não apresenta nessa obra um conceito específico do conceito de "social". O mais próximo que Honneth chega de uma definição aparece na conclusão do livro: o social é "uma relação comunicativa institucionalmente mediada entre grupos culturalmente integrados que, uma vez que o exercício do poder é distribuído de forma assimétrica, ocorre por meio da luta social"93, e que é constituído por " construções frágeis que mantêm sua existência dependente do consenso moral de todos os participantes" "94. O "social" é tomado ao mesmo tempo como o lugar de um poder assimétrico, luta social e como consenso moral. É exatamente a ambiguidade desse conceito que define o "social" como um problema crucial a Teoria Crítica.

Embora Honneth não desenvolva neste livro o conceito de social, ele aponta, no posfácio que escreveu para o livro em 1988, que seu modelo de análise do conflito social pode ser desenvolvido a partir das ideias de Habermas desde que a lógica comunicativa consensual, que orientaria a integração no mundo da vida no modelo que Habermas opta por aprofundar, fosse substituída por uma teoria da integração em que os contatos entre sujeitos são concebidos como uma luta pelo reconhecimento de suas

\footnotetext{
${ }^{90}$ Habermas, 1968b. "A totalidade moral hegeliana de uma contextura da vida, rompida quando um sujeito não satisfaz reciprocamente as necessidades do outro, não é mais o modelo adequado para a relação mediatizada entre as classes na fase tardia do capitalismo organizado"( pág.335).

${ }^{91}$ Honneth, 2003.

${ }^{92}$ Honneth, 1991, p.99.

93 Honneth, 1991, p.303.

94 Honneth, 1991, p.302.
} 
identidades, de modo que o conflito social remete a demandas morais dos sujeitos. Esta opção é a que Honneth entende que Habermas abandonou ao tentar explicar o processo de racionalização humana como um processo dual entre sistema finalista e um mundo da vida comunicativo. Em vez disso, seria possível optar por um segundo desenvolvimento da teoria da comunicação, no qual o conceito de ação comunicativa representaria um "indicador para os mecanismos pelos quais a organização de todos os domínios sociais de ação são regulados"95. Isto é, Honneth aposta que o caminho efetivamente mais frutífero para uma teoria crítico-comunicativa seria aquele que identifica o papel da interação dos sujeitos como um elemento organizador da vida social que estaria presente tanto nos processos macrossociais quanto nos processos internos aos grupos e comunidades. Neste sentido, também ocorreria uma mudança quanto ao destinatário da Teoria Crítica, já que Habermas centrava sua teoria na análise de lógicas de ação e Honneth, ao contrário, trata da interação dos sujeitos determinados, atores que organizam comunicativamente os domínios de ação social.

Com isso, já é possível identificar que a crítica de Honneth à Teoria Crítica serve de entrada à construção de um modelo teórico do reconhecimento que se sustente nos avanços propostos por Habermas à ideia original de Horkheimer. Estes avanços seriam representados de modo privilegiado na constatação de que a "identidade coletiva é um produto do processo de socialização realizado entre os indivíduos", uma vez que aí está expressa a importância da interação comunicativa para a Teoria Crítica. Diferentemente de Habermas, contudo, Honneth não se limita a tomar esta relação como uma lógica universal abstrata, mas a toma como um elemento efetivo da vida social. Ou seja, a interação no seu modelo é muito mais determinada do que no modelo habermasiano. Ela é um procedimento presente na vida individual e sem o qual a formação da identidade não pode ser bem-sucedida. A interação, então, assume o posto de um campo de experiência intersubjetiva, enquanto no modelo habermasiano ela seria um tipo universal de ação. Ocorre que nesta valorização da teoria da intersubjetividade encontram-se, ainda que apenas esboçados, os elementos ausentes nas gerações anteriores da Teoria Crítica e que Honneth só desdobrará em sua teoria do reconhecimento: o conflito intersubjetivo, a formação social da personalidade e o reflexo de ambos na integração social. Estes elementos servem, por um lado, para sustentar a crítica do "déficit sociológico" e, por outro lado, para indicar que uma teoria

\footnotetext{
${ }^{95}$ Honneth, 1991, p.276.
} 
moral da formação da personalidade deveria tratar da integração social como uma questão normativa. No próximo capítulo, tentaremos explicitar esse modelo proposto por Honneth a fim de elucidar o conceito de "social" a ele subjacente. 


\section{PARTE II: TEORIA DO RECONHECIMENTO}

\section{A RETOMADA DO "SOCIAL" A PARTIR DE UMA TEORIA DO RECONHECIMENTO}

Para Honneth, como é possível depreender de sua análise de "Teoria Tradicional e Teórica Crítica", a principal especificidade da Teoria Crítica se refere ao fato de sua ligação com a prática ser definida pela existência de uma zona pré-teórica de prática moral cotidiana intimamente ligada a um interesse emancipatório. Embora esse conceito extrapole a filosofia da História centrada no trabalho pressuposta por ele, segundo Honneth, Horkheimer consegue identificar uma esfera da ação que permite a mediação entre as formas da vontade do indivíduo e o desenvolvimento social. No entanto, os modelos que se seguiram à formulação original de Horkheimer não desenvolveram a análise dessa esfera. No caso da Dialética do Esclarecimento, que Horkheimer escreve em parceria com Adorno, esta ausência se deve à presença forte de um conceito de trabalho no qual se concentram não apenas as relações materiais e econômicas da organização social, mas a própria potencialidade da auto-realização moral dos seres humanos; quando afirmam que no ato mesmo de apropriação da natureza se estabelece uma relação de dominação, baseados na tradução não mediada de uma antropologia reducionista para a teoria da cultura e para a filosofia da História, eles são levados a um diagnóstico de perda da personalidade dos sujeitos sociais graças à dominação dos aparatos reificados e totalizantes da produção social. A explicação de Foucault, por sua vez, é marcada por um funcionalismo que o impede de perceber mesmo a dimensão psíquica da perda de identidade, pois se concentra apenas no desenvolvimento e estabelecimento de técnicas de controle social. Por fim, Habermas, apesar de tentar reconstruir a própria noção antropológica na base da qual se apoia a Teoria Crítica, por meio da afirmação de que a formação do sujeito não ocorre apenas por meio do trabalho, mas também na interação intersubjetiva, acaba levado a diagnosticar uma relação de dominação do sistema racionalizador sobre as esferas comunicativas do mundo da vida. No entanto, este diagnóstico aponta que, para sua teoria, a formação de esferas de comunicação livre é o ponto central do desenvolvimento humano, de modo 
que a ação social tende a desaparecer de sua análise. Assim, ao mesmo tempo em que aponta um caminho renovado para as possibilidades de emancipação, algo que Horkheimer e Adorno passaram a ver como impossível, Habermas abandona a ideia de que o interesse emancipatório deve se situar nas próprias relações sociais.

Para Honneth, portanto, a tradição crítica incorre em um "déficit sociológico", ou seja, ausência de uma esfera social que promova a mediação entre formação da vontade e o processo de desenvolvimento social. O que segundo seu diagnóstico se desdobra em um abandono da capacidade de transcendência. Assim, portanto, para Honneth, a principal tarefa de uma teoria crítica reconstruída é buscar uma explicação para a dominação social ao mesmo tempo em que aponta os meios para sua superação. Para tanto ele retira os conceitos não desenvolvidos dos modelos críticos anteriores para a partir deles desenvolver seu próprio modelo.

Honneth se propõe a retomar as tarefas delineadas por Horkheimer a partir do caminho seguido por Habermas de uma desontologização do conceito de trabalho. No entanto, diferente de Habermas que desenvolve seu modelo teórico da "Teoria da Ação Comunicativa" 96 como uma teoria da alienação da racionalidade humana frente ao crescente poder tecnocrata, Honneth busca garantir o potencial emancipatório de sua teoria a partir do sofrimento da injustiça que os indivíduos experimentam devido a um ataque a sua identidade formal nos processos de comunicação social. Para Honneth uma filosofia que relega em segundo plano a justificação moral corre o risco de não ser capaz de converter-se em práticas concretas de superação da dominação:

a motivação subjacente aos atos políticos de resistência, ou, no caso,
qualquer tipo de ação de protesto, não é uma orientação para
princípios positivos moralmente formulados, mas sim a experiência da
violência contra as concepções de justiça intuitivamente
pressupostas. ${ }^{97}$

A violência sofrida assume a forma de uma injustiça moral principalmente quando dirigida às demandas individuais ou morais pelo reconhecimento social. Assim, portanto, a idéia hegeliana de uma luta por reconhecimento, aparece a Honneth como ponto de partida para interpretação da esfera de ação social prática moral na qual o

\footnotetext{
${ }^{96}$ Habermas,1992 e1999.

${ }^{97}$ Honneth, 1995, pág. Xiv.
} 
sujeito forma sua identidade e luta por reconhecimento. No âmbito do espaço social a emancipação é observada pré-teoricamente como forma de auto-realização ${ }^{98}$. É a partir desse modelo que Honneth consegue reaver a ideia normativa como parte das expectativas dos sujeitos, algo que Horkheimer não conseguira mais realizar após sua descrença no proletariado e o modelo de competição entre sistema e mundo de vida de Habermas excluíra. O conceito de luta por reconhecimento permite Honneth restituir o espaço do "social" a Teoria Crítica, de forma que torne possível a investigação dos fenômenos empíricos que permitem prover a Teoria Crítica da capacidade crítica que existe, ao menos potencialmente, no modelo de Horkheimer. ${ }^{99}$

Para Honneth, os protestos dos grupos desfavorecidos decorrem do sentimento de desrespeito à sua capacidade de agir ativamente na sociedade. $\mathrm{O}$ desrespeito seria vivenciado como um ataque a integridade do sujeito, visto que o pressuposto de uma relação comunicativa é o reconhecimento recíproco entre os sujeitos como parceiros de igual status. O sentimento de injustiça moral, portanto, é interpretado como um sentimento de desrespeito social e possibilita a Honneth estabelecer a ligação entre tipos de violação às expectativas dos sujeitos e suas experiências comunicativas. Essa violação é expressa por valores morais negativos da vergonha, raiva e indignação, por exemplo. Assim, segundo Honneth,

um paradigma comunicativo concebido não em termos de uma teoria da linguagem, mas em termos de um teoria do reconhecimento, pode, em última instância, fechar a lacuna deixada aberta por Habermas em seu desenvolvimento do programa de Horkheimer. Os sentimentos de injustiça que acompanham as formas estruturais de desrespeito representam um fato pré-teórico, em cuja base uma crítica das relações de reconhecimento pode identificar sua própria perspectiva na realidade social. ${ }^{100}$

A proposta de Honneth aparece como uma renovação do espaço "social" concebido como esfera intersubjetiva no qual o conflito entre os sujeitos é uma questão moral, responsável por sua formação bem sucedida. No artigo "Integrity and Disrespect:

\footnotetext{
98 "The social dynamics of disrespect" in Honneth, 2007.

99 "The social dynamics of disrespect" in Honneth, 2007.

100 "The social dynamics of disrespect" in Honneth, 2007. Pág. 72.
} 
Principles of a Conception of Morality Based on a Theory of Recognition", 101 publicado em uma leitura inaugural na universidade de Frankfurt, em 1990, Honneth afirma em comentário sobre Ernst Bloch, a necessidade de retomar a área da prática moral a partir da teoria de reconhecimento. Segundo Honneth, o conceito de dignidade, está intimamente ligado às formas de reconhecimento intersubjetivo. Assim, portanto, a aproximação do espaço social deve-se dar através dos danos e distorções das relações sociais de reconhecimento, ou seja, o diagnóstico da Teoria Crítica deve se ater às patologias de socialização que limitam o reconhecimento e dessa forma impedem os processos de formação da identidade do indivíduo. Segundo Honneth, no entanto, essas patologias devem ser entendidas no sentido de desordens da vida social proposta por Émile Durkheim, isto, por que são situações que prejudicam a vida coletiva por meio de um ataque a individualidade. ${ }^{102}$

A aproximação às patologias sociais modernas só pode ser feita negativamente, isto é, a partir da ameaça à dignidade da pessoa, entendida como negação do reconhecimento intersubjetivo da capacidade do sujeito, a ponto de este não conseguir ver a si mesmo de maneira positiva. Dessa forma, as patologias sociais (ameaça à identidade do sujeito) são concebidas como distorções nas relações comunicativas de reconhecimento intersubjetivo e, consequentemente, na possibilidade da auto-afirmação dos sujeitos. Em oposição a essa definição, Honneth também define o conceito de moralidade. Para ele a garantia do reconhecimento representa a infraestrutura moral de uma vida social em que os indivíduos adquirem e garante sua integralidade ${ }^{103}$. A moralidade, portanto, contém inerentemente as condições básicas para uma socialização pautada pelos valores do reconhecimento intersubjetivo. Mas, para Honneth, o espaço prático de realização do sujeito se deve, antes, aos sentimentos de desrespeito do que aos sentimentos positivos como o altruísmo.

De acordo com Honneth, a vergonha como demonstra os estudos psicanalíticos e fenomenológicos é o mais aberto dos sentimentos humanos e possui necessariamente um caráter social, visto que pressupõe a existência de um parceiro frente ao qual o sujeito experimenta um sentimento de rebaixamento de sua auto-estima. Quando este rebaixamento se deve ao parceiro de interação, diz Honneth, ocorre uma violação das

\footnotetext{
101 “Integrity and Disrespect" in Honneth, 1995.

${ }^{102}$ Ver "the social dynamics of disrespect", especialmente a parte iv "Pathologies of capitalist society" in Honneth, 2007.

103 "integrity and disrespect", in Honneth,1995.
} 
normas morais que o próprio sujeito esperava que fossem respeitadas e dessa forma tem início os conflitos morais pelo restabelecimento de uma interação comunicativa pautada pela moralidade. Assim, portanto, para Honneth, uma teoria da intersubjetividade tomada a partir do ponto de vista negativo, possibilita uma maior aproximação às experiências empíricas de desrespeito moral. A partir dessa linha de pensamento, Honneth retoma o sistema de Eticidade desenvolvido pelo jovem Hegel, a fim de apresentar uma concepção formal de luta por reconhecimento.

O conceito de "luta por reconhecimento" é buscado na obra de Hegel, mais precisamente em seus escritos de juventude, em Jena, no qual desenvolvera um sistema de eticidade baseado na concepção central de que a realização humana era oposta à tradição da política clássica, que remontava a Nicolau Maquiavel e Thomas Hobbes: ao invés do indivíduo solitário em busca da maximização de suas capacidades, Hegel enxergava na interação social e na certeza do respeito do outro os meios para a formação e auto-realização do sujeito. Para isso seriam necessárias três etapas de ralações sociais em que aquela certeza poderia se formar: a primeira nas relações amorosas, em que o sujeito aprende a conceber-se como completo apenas no outro; a segunda, nas relações de competição entre sujeitos, em que o sujeito aprende a respeitar o outro e a si mesmo; e a terceira, na comunidade ética, em que o sujeito aprende a valorizar o outro e espera a valorização de si mesmo. Para que, no entanto, Honneth possa utilizar o sistema hegeliano para reconstrução da Teoria Crítica, ele deve evitar o caráter idealista e metafísico que marca o trabalho de Hegel.

A teoria do reconhecimento encontrada em Hegel, então, é trazida por Honneth para um contexto pós-metafísico com vistas a alcançar dois objetivos. Primeiro, retrabalhar as formas de reconhecimento a partir de uma perspectiva empiricamente válida; e segundo, construir formas de destruição daquele reconhecimento que permitam legitimar a ideia hegeliana de que é por meio de uma luta por reconhecimento que os sujeitos atingem a sua auto-realização. Dessa forma, fica explícito seu objetivo, que é o de "esclarecer os processos de mudança social reportando-se às pretensões normativas estruturalmente inscritas nas relações de reconhecimento recíproco" ${ }^{104}$. O controle empírico objetivado por Honneth é encontrado na psicologia social de George Herbert Mead, que procurara apresentar o processo psicológico de formação da identidade como uma relação intersubjetiva

\footnotetext{
${ }^{104}$ Honneth, 2003, pág. 155.
} 
conflituosa em que o sujeito adquire novas capacidades de auto-reconhecimento a cada etapa de ampliação de seu círculo social, da família à divisão social do trabalho, passando pela atribuição de direitos.

Uma vez estabelecida esta formulação empírica da tipologia hegeliana, Honneth pretende, finalmente, apresentá-la como um movimento por meio do qual, positivamente, os sujeitos formam auto-relações por meio da satisfação de suas expectativas normativas nas relações com outros sujeitos. A tipologia do reconhecimento, então, é apresentada como um processo intersubjetivo no qual em três fases, as relações primárias, a atribuição de direitos e a solidariedade social, o sujeito pode se auto-realizar por meio da formação da auto-confiança, do auto-respeito e da auto-estima. Contudo, negativamente, também é possível que se formem danos à personalidade dos sujeitos quando estas expectativas não são cumpridas. Daí que a cada um dos termos positivos ele identifica uma relação negativa: a violência, a privação de direitos e a degradação, que atacam diretamente aquelas auto-relações. Na busca de superação das ameaças à auto-realização, então, Honneth vê a capacidade do sujeito de lutar por reconhecimento.

É a construção da tipologia do reconhecimento que será tratada na próxima secção, primeiro em seu conteúdo positivo e depois nas ameaças à integridade do sujeito, com vista a esclarecer a estrutura das relações sociais e dessa forma, realizar a tarefa pretendida por Honneth, ou seja, reatualizar a Teoria Crítica da sociedade tal como definida originalmente por Horkheimer.

\section{RECONHECIMENTO E DESRRESPEITO: ESTRUTURA DAS RELAÇÕES SOCIAIS DO RECONHECIMENTO}

\subsection{Reconhecimento como auto-realização}

Uma teoria do reconhecimento tal como pretendida por Honneth deve situar o reconhecimento recíproco como base da interação social. Para isso, além de admitir, como fizeram Hegel e Mead, que as relações de reconhecimento recíproco são responsáveis pela auto-realização prática dos sujeitos, isto é, depende da auto-percepção 
dos indivíduos enquanto destinatários sociais das ações de seus parceiros de interação, Honneth deve concebê-las também como fundamento da vida coletiva. Ou seja, a formação da identidade deve ser entendida como aceitação dos valores e normas culturais diferentes. Somente a partir dessa perspectiva, segundo Honneth, é possível entender as formas de reconhecimento como uma teoria social, isto é, estabelecer uma relação entre as lutas moralmente motivadas de grupos sociais pelo reconhecimento de suas formas de vida aos processos de mudança histórica. As demandas pela ampliação do reconhecimento só se tornam conhecidas, diz Honneth, quando o conflito psicológico pelo respeito do outro reverbera em determinado grupo social e dessa maneira constitui um luta coletiva por reconhecimento. Para o movimento de reconstrução da Teoria Crítica, porém, Honneth precisa confirmar a relação entre a tripartição estabelecida por Hegel e Mead e as fontes empíricas e também procurar oferecer quais as formas de desrespeito que originam a luta por reconhecimento, isto é, determinar quais são, afinal, as patologias da sociedade capitalista. Isto significa um passo além da simples definição, oferecida até o momento, de que as áreas pré-teóricas de prática moral são marcadas por relações de reconhecimento recíproco, pois agora Honneth é levado a esclarecer quais os meios pelos quais se formam as auto-relações de reconhecimento que representam a base normativa do seu modelo de teoria social. Honneth pretende, portanto, explorar o conteúdo concreto das relações de amor, direitos e solidariedade, a fim de demonstrar sua legitimidade como esferas de reconhecimento. ${ }^{105}$

O primeiro tipo de reconhecimento, o amor, segundo Honneth, decorre das relações primárias que exprimem ligações emotivas. Em conformidade com Hegel, diz Honneth, o reconhecimento nesta esfera apresenta caráter duplo de autonomia e ligação com o parceiro de interação, por isso, pode ser interpretado como uma luta por reconhecimento. A relação afetiva é marcada inicialmente por uma relação de dependência mútua entre a criança e a mãe. No caso do bebê a dependência para com a mãe, figura protetora, é tão grande que nem é possível falar em sujeito isolado ${ }^{106}$; no caso da mãe, a dependência se deve ao fato de que existe um efeito psicológico de

\footnotetext{
${ }^{105}$ Honneth,2003.

${ }^{106}$ Honneth,2003. No quadro de uma nova psicanálise, surgida no começo do século XX em busca de distanciamento das idéias de Freud, a problemática da dependência mútua em relação a criança e a mãe é transformada em uma investigação sobre a formação da noção de autonomia dos sujeitos durante sua infância. Para Donald W. Winnicott, por exemplo, essa relação de dependência mútua é ignorada pela psicanálise tradicional, o que leva a necessidade de uma análise sobre a formação da autonomia da criança.
} 
projeção no outro ser, de modo que até mesmo os cuidados consigo mesma tem como finalidade o interesse de preservação de ambos. O processo no qual a mãe e o filho aprendem a se formar como pessoas diferenciadas, é marcado pelo rompimento dessa "intersubjetividade primária", produz, portanto, efeitos tanto na criança como na mãe, pois a necessidade de diferenciação é recíproca. A mãe amplia seu espaço de atenção social e o bebê, por sua vez, diferencia a si mesmo do âmbito social, de modo que fica exposta para ele sua dependência material de outro externo para satisfação de seus impulsos, que ele começa a perceber nessa fase. Nos termos de Hegel, nesse momento, tem início à formação do "ser-em-si-mesmo-no-outro", no qual a percepção da autonomia do outro implica uma relação conflituosa ${ }^{107}$. A criança traça uma fronteira simbólica de separação entre si e sua mãe sem romper definitivamente sua dependência. Assim, diz Honneth, a relação afetiva entre ambos pode ser entendida nos termos Hegelianos de uma luta por reconhecimento, no qual o objetivo do conflito é a superação de uma relação de dependência total em favor de uma relação dupla no qual do lado de uma dependência, material ou psicológica, se coloca a percepção do outro como sujeito autônomo. ${ }^{108}$

A fase que se segue à separação cognitiva entre o bebê e mãe corresponde ao desenvolvimento da capacidade infantil para estabelecimento de ligações sociais. A formação de uma autonomia básica permite que a criança passe a dedicar sua afeição a objetos transitórios. Isto, por que, a garantia do amor materno lhe confere confiança para dedicar-se afetivamente a "outros objetos". Assim, Honneth delineia o primeiro tipo de auto-relação. Com confiança na satisfação de suas necessidades a criança pode dar atenção a outros impulsos internos que não os da sobrevivência. Por isso a ausência de medo de abandono é a expressão da relação consigo mesmo que o indivíduo pode chamar de "auto-confiança"109. Assim, portanto, a noção de amor revela, por um lado, que o reconhecimento funciona como um movimento de autonomia quando a relação amorosa se constrói como uma interação bem sucedida, e por outro lado, a autoconfiança que os sujeitos desenvolvem com a certeza do reconhecimento é um pressuposto para qualquer outra forma de relação futura.

\footnotetext{
${ }^{107}$ Honneth,2003. O reconhecimento por meio do amor não se restringe a relação materna. O uso dessa relação é dada como exemplo apenas devido a esta ser a mais óbvia forma de relação primário, mas esse tipo de reconhecimento também poderia ser enxergado em também em relações amorosas, como o faz Hegel, ou ainda em relações de amizade, uma vez que todas estas são relações nos quais se estabelece aquele tipo de dependência que caracteriza o "ser-em-si-no-outro".

108 Honneth, 2003.

${ }^{109}$ Honneth,2003, pág. 174.
} 
Segundo Honneth, o movimento de percepção dos direitos que cabem a cada indivíduo obedece a mesma operação de formação das condições de participação positiva do indivíduo. Assim como a percepção do bebê como sujeito autônomo depende da percepção de si mesmo a partir da perspectiva do outro externo, o indivíduo é capaz de compreender-se como portador de direito na medida em que se torna capaz de ver a si mesmo a partir da perspectiva de um "outro generalizado". Essa percepção do sujeito como portador de direito, representa a percepção na qual algumas de suas pretensões podem ser legitimamente respeitadas ${ }^{110}$. No entanto, a noção de reconhecimento no direito, diferente da relação amorosa, tem caráter histórico. Só pode ser legitimada com a passagem às formas de direito moderno. Somente com o abandono das sociedades tradicionais o reconhecimento jurídico passa a ser relacionado às capacidades individuais ao invés da posição social da pessoa em um processo gradual de abandono do status social em favor da moral pós-convencional. Esse caráter histórico, segundo Honneth, é negado tanto na formulação universalista de Hegel como no pragmatismo de Mead. Enquanto Mead se limita a oferecer uma fundamentação psicológica ao fato de que todo ser humano pode ser portador de direitos; Hegel, embora, afirme que o reconhecimento no direito só ocorre após a universalização dos princípios morais nas sociedades pós-tradicionais, rompendo totalmente com a autoridade tradicional para a definição da noção jurídica que orienta o ideal de uma boa vida, entende o reconhecimento que universaliza a condição da autonomia dos sujeitos apenas como uma operação cognitiva, livre de emoções, o que impede que este tipo de respeito influencie o comportamento interpessoal. ${ }^{111}$

Para Honneth, no que diz respeito às relações jurídicas, a garantia e o estabelecimento do respeito mútuo depende de um acordo racional acerca da capacidade universal dos seres humanos. Isto porque a garantia do respeito mútuo depende justamente do reconhecimento da imputabilidade moral de todos os membros da comunidade. A legitimidade do direito provém do fato de que todos os membros da comunidade são considerados aptos a decidir sobre questões morais. Assim, as propriedades de reconhecimento acabam sendo submetidas à representação do procedimento por meio do qual se realiza o acordo. Os pressupostos sociais da participação racional é o que determina as propriedades a serem reconhecidas como universalmente humanas.

\footnotetext{
110 "integrity and disrespect" in Honneth, 1995.

${ }^{111}$ Honneth,2003.
} 
a definição das propriedades que caracterizam o ser humano constitutivamente como pessoa depende das assunções de fundo acerca dos pressupostos subjetivos que capacitam para a participação numa formação racional da vontade: quanto mais exigente é a maneira pela qual se pensa um semelhante procedimento, tanto mais abrangentes devem ser as propriedades que, tomadas em conjunto, constituem a imputabilidade moral de um sujeito ${ }^{112}$

Assim, portanto, para Honneth, as capacidades juridicamente reconhecidas podem ser alteradas de acordo com situação social vigente e, nas condições da fase póstradicional, a atribuição de direitos segue a direção da ampliação do conteúdo prático das capacidades legítimas do sujeito, ou seja, da ampliação das expectativas cabíveis dentro do quadro de valores universais. Para Honneth, a inclusão do sujeito na visão abstrata do valor universal enquanto ser humano, não significa a valorização deste enquanto sujeito de direitos iguais. O reconhecimento jurídico efetivo só vem à tona quando a limitação da conduta do indivíduo se dá a partir da percepção das necessidades consideradas legítimas do outro. Assim, diz Honneth, a estrutura do reconhecimento jurídico aparece sob a forma bidimensional de universalização e aplicação do direito em que ao mesmo tempo em que se constrói um saber moral sobre a norma jurídica de respeito universalizado para com o outro, é preciso também um conhecimento empírico desde outro, a fim de saber se suas demandas são, de fato, merecedoras de reconhecimento. Esse movimento permite a Honneth interpretar a relação jurídica também a partir da forma de uma luta por reconhecimento:

na estrutura do reconhecimento jurídico, justamente por que está constituída de maneira universalista sob as condições modernas, está infrangivelmente inserida a tarefa de uma aplicação específica à situação: um direito universalmente válido deve ser questionado, à luz das descrições empíricas da situação, no sentido de saber a que círculo de sujeitos ele deve se aplicar, visto que eles pertencem à classe de pessoas moralmente imputáveis. Nessa zona de interpretações das

112 Honneth, 2003,p.188. 
situações referidas à aplicação, as relações jurídicas constituem (...) um dos lugares em que pode suceder uma luta por reconhecimento $^{113}$

A ampliação dos direitos individuais, portanto, é entendida como fruto de uma luta por reconhecimento. Segundo Honneth, esta deve ser concebida no sentido daquelas pressões identificadas por Thomas H. Marshall, como luta pela ampliação da atribuição dos status igualitário entre os membros da comunidade. Assim o processo de alargamento dos direitos fundamentais evidencia a relação entre a valorização jurídica e atribuição moral de uma capacidade racional do mesmo indivíduo. O processo de ampliação dos direitos sociais ocorre sob um movimento duplo de ampliação material e social. Por um lado, tem-se o processo de ampliação objetiva do status de uma pessoa, decorrente da observação de princípios da igualdade, de forma que as chances de realização pessoal sejam democratizadas; por outro lado, no nível social, acontece uma ampliação do número de cidadãos considerados membros da sociedade. A ampliação social do direito visa, assim, garantir a inclusão cada vez maior de grupos nas relações igualitárias. Esse duplo movimento é definido por Hegel e Mead como processo de luta por reconhecimento na esfera do direito.

os confrontos práticos que se seguem por conta da experiência do reconhecimento denegado ou do desrespeito, representam conflitos em torno da ampliação tanto do conteúdo material como do alcance social do status de uma pessoa de direito ${ }^{114}$

Antes, no entanto, de analisar as formas de desrespeito, Honneth precisa esclarecer a auto-relação associada ao reconhecimento jurídico. Segundo ele, o "autorespeito" decorre da percepção do sujeito sobre si mesmo como ser moral cuja autonomia de ação é respeitada por todos devido a uma situação de reconhecimento jurídico. O "auto-respeito", portanto, como entendido por Honneth, só pode tornar-se fonte de respeito e capacidade de ação social de uma pessoa nas condições de universalidade. Apenas sob tal condição é possível que os sujeitos atribuam uns aos outros aquela imputabilidade moral na qual se baseia o respeito jurídico.

\footnotetext{
${ }^{113}$ Honnth, 2003, pág. 186.

${ }^{114}$ Honneth, 2003, pág.194.
} 
um sujeito é capaz de se considerar, na experiência do reconhecimento jurídico, como uma pessoa que partilha com todos os outros membros de sua coletividade as propriedades que capacitam para a participação numa formação discursiva da vontade; e a possibilidade de se referir positivamente a si mesmo desse modo é o que podemos chamar de auto-respeito ${ }^{115}$

Ao contrário do amor, porém, a confirmação empírica da existência do reconhecimento empírico somente pode ocorrer por uma aproximação negativa, que revele sua ausência e, em determinados casos, a luta pela sua existência, de forma que começa a aparecer a necessidade, já colocada por Honneth, de identificar as formas de desrespeito que fazem do reconhecimento a forma positiva de integração social. Antes, no entanto, Honneth precisa esclarecer um terceiro tipo de reconhecimento. A "estima social", ou "solidariedade", nos termos de Hegel, está relacionada com uma "avaliação gradual de propriedades e capacidades concretas" ${ }^{116} \mathrm{da}$ personalidade do sujeito em questão. Ao invés do universalismo da norma jurídica, o que vem à tona nesta situação é uma avaliação valorativa. Dessa distinção, então, decorre para Honneth que o próprio objeto do reconhecimento é visto a partir de duas perspectivas diferentes. Se ao reconhecimento jurídico interessa a determinação do valor humano universal, à estima social é o estabelecimento dos valores de aceitação comunitária o que interessa.

em ambos os casos (...) um homem é respeitado em virtude de determinadas propriedades, mas no primeiro caso se trata daquela propriedade universal que faz dele uma pessoa; no segundo caso, pelo contrário, trata-se das propriedades particulares que o caracterizam, diferentemente de outras pessoas. Daí ser central para o reconhecimento jurídico a questão de como se determinar aquela propriedade constitutiva das pessoas como tais, enquanto para a estima social se coloca a questão de como se constitui sistema referencial valorativo no

\footnotetext{
${ }^{115}$ Honnth,2003, pág. 197.

${ }^{116}$ Honneth, 2003, pág. 186.
} 
interior do qual se pode medir o "valor" das propriedades características"

No entanto, o reconhecimento da estima social, de acordo com Honneth, está intimamente ligado com ao reconhecimento jurídico. Essa forma de reconhecimento depende, por um lado, do quadro pós-convencional do direito, isto é, depende das garantias do status igualitário e também da concepção abstrata e universalista de um conjunto de valores comuns; por outro lado, constitui a possibilidade de positivação do direito, já que este processo é mediado por sentimentos de aceitação e solidariedade social. Assim, portanto, esse terceiro tipo de reconhecimento, bem como a auto-relação correspondente, no qual o sujeito pode observar de maneira positiva sua particularidade e capacidades só pode ser esclarecido no mesmo contexto histórico do reconhecimento jurídico da autonomia moral.

Segundo Honneth, Hegel e Mead construíram o conceito de solidariedade em termos normativos na qual toda a forma de reconhecimento relacionada ao status estava sob a forma de uma comunidade de valor. Honneth segue o mesmo caminho, pressupõe a existência prévia de um horizonte compartilhado de valorização a partir do qual os indivíduos podem reconhecer e valorizar a contribuição do outro para a vida social, mas ao mesmo tempo esta relação vai além destes limites "incorporando um elemento emocional de solidariedade e empatia"(incorporating an emotional elemento of solidarity and sympathy $)^{118}$.

Assim, portanto, para Honneth, o reconhecimento das particularidades dos sujeitos depende de um compartilhamento de símbolos em que se formam as normas e valores culturais e éticos nos quais se assenta o auto-entendimento de uma comunidade. Honneth usa o conceito "intersubjetividade vinculante" "119 para descrever essa vinculação ao quadro de uma auto-entendimento a partir do qual as propriedades particulares dos membros da comunidade têm seu valor medido, dado que é o julgamento intersubjetivo dos outros membros sobre a contribuição de determinada capacidade individual que determina simbolicamente seu grau de estima social. Assim a estima social depende tanto dos valores compartilhados pela comunidade quanto da abertura à pluralidade que esta demonstra e dessa forma remete ao mesmo quadro

\footnotetext{
${ }^{117}$ Honneth, 2003, pág.1987.

118 "integrity and disrespect", p. 225 in Honneth, 1995.

${ }^{119}$ Honneth,2003 p.199.
} 
histórico do reconhecimento jurídico universal. Desse modo, ao mesmo tempo em que seu modelo parece apontar para os valores comunitários do reconhecimento da diferença, este tipo de relação deve sua existência às garantias de status igualitário já alcançado. Assim, a solidariedade não é devida a qualquer forma de manifestação de valores, mas apenas àquelas que podem ser legitimadas pela imputabilidade racional da comunidade e pela concepção abstrata e universalista de um conjunto de valores comuns. ${ }^{120}$

Segundo Honneth, somente com a passagem das sociedades tradicionais para as modernas a valorização social dirige-se fundamentalmente para a individualidade. A partir dessa perspectiva Honneth pretende reformular o conceito de solidariedade empiricamente com vista a formular uma concepção formal de eticidade. Segundo suas análises, a mudança de organização social com a passagem as sociedades modernas pode ser conceitualmente expressa pela substituição do conceito de "honra", pela qual os sujeitos cumpriam expectativas de seus grupos, pelo "prestígio social", com o qual seu valor se torna medido em termos individuais. Nas sociedades tradicionais as relações sociais assumiam um duplo caráter: dentro do grupo do qual os indivíduos faziam parte elas eram simétricas e compartilhadas, e do lado de fora rígidas e hierarquizadas, ainda que constituíssem parte de um quadro estável de reconhecimento. Isto é, mesmo nas sociedades hierarquizadas as relações de reconhecimento podem ser identificadas, porém não são tornadas positivas, pois não se baseiam em uma situação de status igualitário, como aquele trazido pela universalização do direito moderno. ${ }^{121}$

A superação da cosmologia tradicional pelas lutas burguesas significa para as relações de status e estima social uma dupla revolução. A primeira, um nivelamento moral até então inexistente naquelas sociedades; a segunda, o surgimento da idéia de vida particular, fora de um grupo social rigidamente determinado. A honra é substituída pela personalidade que extrapola o tipo de reconhecimento universalista juridicamente assegurado como medida de status social: "uma pessoa só pode se sentir 'valiosa' quando se sabe reconhecida em relações que ela justamente não partilha de maneira indistinta com todos os demais". ${ }^{122}$ Como consequência, na modernidade, tem-se uma valorização da biografia do sujeito e consequentemente a emergência da luta por auto-

\footnotetext{
${ }^{120}$ Sobre as relações entre universalismo e particularismo dentro da estrutura estatal ver Habermas,2004, "Lutas por reconhecimento no Estado democrático Constitucional".

${ }^{121}$ Honneth,2003.

122 Honneth,2003, p.204.
} 
realização. As pretensões de reconhecimento do sujeito são as referentes à sua autorealização. Este processo constitui o fundamento da modernidade, a hierarquia das identidades sociais é substituída por uma forma de diferença igualitária. ${ }^{123}$

O prestígio social continua definido a partir de valores intersubjetivamente partilhados, no entanto, na modernidade, esses valores são orientados pela ideia de individuação das relações sociais. A possibilidade de proporcionar amplas possibilidades de auto-realização assume caráter central para teoria do reconhecimento $^{124}$. Dessa maneira, a esfera da solidariedade pode ser definida como uma combinação entre a formação intersubjetiva de valores comuns e a pluralidade de opções e capacidade para a realização desses valores.

Para Honneth, porém, a validade empírica da terceira forma de reconhecimento, ou seja, a valorização das expectativas particulares depende de uma prática que a torne legítima antes de ser estimada socialmente. A valorização de determinadas normas coletivas deve ser construída por meio de um grupo capaz de instaurar uma luta na sociedade pela valorização e legitimar suas normas e valores. Assim, tal como o reconhecimento de direitos universalizados, a obtenção de estima social possui a estrutura de uma luta por reconhecimento social.

As lutas por reconhecimento jurídico e de estima social se aproximam por um lado, em contraste com a relação afetiva entre a criança e a mãe, pelo caráter histórico que ambos possuem. Enquanto nas relações afetivas a luta por reconhecimento se mantém na esfera particular da vida e dessa forma não podem ser universalizadas, as lutas "sociais" por reconhecimento apenas obtém validade na esfera social, onde as formas de reconhecimento precisam ser legitimadas por meios de práticas que demonstrem seu valor para totalidade da comunidade. Por isso os dois últimos tipos de luta social devem ser entendidos como partes de processos históricos de ampliação do escopo do reconhecimento, enquanto no primeiro caso a dimensão histórica pode ser ignorada na medida em que se trata de uma relação interpessoal. Por outro lado, as lutas por ampliação dos direitos e pela obtenção da estima social são distintas, enquanto as primeiras buscam legitimar a visão de moral de igualdade, e desta forma tornar mais amplo o número de pessoas aceitas pela sociedade, as últimas buscam ampliar o número de formas de vida respeitadas pela sociedade.

\footnotetext{
${ }^{123}$ Honneth, 2003.

${ }^{124}$ Honneth,2003.
} 
A luta por estima social deve, portanto, ser entendida no sentido atribuído por Pierre Bourdieu, ou seja, como uma luta simbólica pela elevação do prestígio do grupo pelas partes envolvidas. Esse tipo de luta não se refere exclusivamente à luta formal entre grupos organizados, nem a luta por dominação simbólica, mas a um conflito no qual os grupos de identidade tentam fazer valer suas formas de vida, ou seja, buscam reconhecimento das condições de auto-realização negadas pela desvalorização de suas características de personalidade incontornáveis ${ }^{125}$. Desta forma, os grupos sociais procuram reverter à situação de desrespeito ou aumentar o prestígio social de seus membros e assim:

A estima social assume um padrão que confere às formas de reconhecimento associadas a ela o caráter de relações assimétricas entre sujeitos biograficamente individuados: certamente, as interpretações culturais que devem concretizar em cada caso os objetivos abstratos da sociedade no interior do mundo da vida continuam a ser determinados pelos interesses que os grupos sociais possuem na valorização das capacidades e das propriedades representadas por eles; mas, no interior das ordens de valores efetivadas por via conflituosa, a reputação social dos sujeitos se mede pelas realizações individuais que eles apresentam socialmente no quadro de suas formas particulares de auto-realização ${ }^{126}$.

Para finalizar sua atualização das tipologias de Hegel e Mead, Honneth deve esclarecer a auto-realização propiciada pela estima social. Esta deve ser capaz de estabelecer vínculo entre os sujeitos, visto que depende de uma "intersubjetividade vinculante", ou seja, depende de sua contribuição para a vida social e, por outro lado, deve manter em aberto um espaço para que este vínculo se transforme em autorealização sob a forma de um incentivo às características na forma de um incentivo às características particulares de sua biografia, ou seja, deve ser entendida como processo de formação da identidade. Assim, em paralelo ao sentimento de "auto-confiança" e

\footnotetext{
${ }^{125}$ Ver Honneth, 2003, p.207, nota 97. Honneth estabelece relação entre esta interpretação sobre a obra de Bourdieu com uma tentativa de síntese entre as obras de Marx, Weber e Durkheim.

${ }^{126}$ Honneth, 2003, p.208.
} 
"auto-respeito" surge uma confiança emotiva nos valores de suas realizações que pode ser chamada de "auto-estima", pois se baseia na valorização que o sujeito atribui a si mesmo por se saber dotado de estima dos outros. ${ }^{127}$ Esta, como foi exposto, só é possível no quadro pós-convencional, no qual a estima social entre os sujeitos autônomos é simétrica, implicando na percepção do valor do outro para a comunidade geral. No quadro de uma sociedade em que os valores do reconhecimento são respeitados na esfera da ação coletiva, além da tolerância, se verifica um interesse intersubjetivo entre os sujeitos e uma constante avaliação de seus direitos através de conflitos por meio de uma luta por reconhecimento que se refletiria na ampliação histórica de sua extensão e de seu conteúdo.

\subsection{Desrespeito como Patologia - Ameaça a Integridade do Sujeito}

Na reatualização da teoria do reconhecimento no quadro de uma sociedade póstradicional desenvolvida até aqui, a auto-realização dos sujeitos, possível graças aos processos históricos de individuação, decorre dos padrões de reconhecimento que se referem à vida social, que capacitam o sujeito à ação e à formação da personalidade individual. Assim, portanto, a capacidade de auto-realização depende das relações intersubjetivas. Honneth apresenta um conceito de dignidade humana que significa a integridade completa do indivíduo por meio de formações bem sucedidas das autorelações construídas durante o processo de reconhecimento: a "auto-confiança" formada pelo amor, o "auto-respeito" formado pela atribuição de direitos, e "auto-estima" formada pela solidariedade. Essas relações, segundo Honneth, compõem a zona-moral pré-teórica, e seriam responsáveis pelas expectativas normativas dos sujeitos quanto a seu valor, ou seja, expectativas que os sujeitos esperam ser reconhecidas por outros sujeitos quando levadas a público.

Essa formulação, no entanto, diz Honneth, tem por fim apenas corrigir as falhas nos modelos anteriores da Teoria Crítica em abordar a "infra-estrutura moral das relações sociais" com vistas a esclarecer os processos de pressão e mudança social. O

\footnotetext{
${ }^{127}$ Honneth,2003. Ver o quadro apresentado por Honneth para a tipologia completa na pág.211.
} 
modelo teórico construído por Honneth até aqui pode, portanto, ser associado à primeira tarefa proposta por Horkeimer nos anos de 1930: buscar dentro da realidade a base da teoria emancipatória. Assim, o próximo passo deve ser tomado de forma que seja possível transformar esse enunciado transcendental em uma crítica imanente, ou seja, cumprir a segunda tarefa da Teoria Crítica tal como definida por Horkheimer em “Teoria Tradicional e Teoria Crítica". Honneth deve determinar as limitações efetivas às realizações do reconhecimento de maneira a fundamentar a crítica do real. É a partir das perspectivas normativas contidas no conceito de moralidade desenvolvida no contexto da auto-realização prática que Honneth pretende fundar a partir do desrespeito a integridade do sujeito a capacidade emancipatória da Teoria Crítica.

Uma vez que a integralidade dos seres humanos pode ser considerada como resultado de padrões por reconhecimento encontrados no amor, nos direitos e na esfera social, a inobservância dessas relações impede a realização da personalidade, ou seja, o sujeito sente-se reduzido na própria compreensão que tem de si mesmo, além de ser impedido de realizar-se plenamente em sua liberdade.

O desrespeito, portanto, é visto como uma decorrência negativa, isto é, não comprida, das expectativas que o sujeito tem para com o reconhecimento do outro. Horkheimer pretende retomar os padrões de reconhecimento de forma negativa com vistas a demonstrar a partir de observações empíricas como o desrespeito à individualidade afeta diretamente a auto-realização cujo estabelecimento bem sucedido permite a formulação de identidade. Com isso seria possível responder à questão sobre quais as experiências motivacionais para a luta social por reconhecimento e qual a relação afetiva para com esta luta ${ }^{128}$.

O primeiro tipo de desrespeito está relacionado de maneira oposta às relações amorosas. Corresponde, portanto, a destruição daquela dedicação afetiva aprendida nos primeiros estágios de vida, afetando diretamente a confiança trazida pelo amor de que as necessidades do sujeito seriam satisfeitas e que este poderia dispor de seu próprio corpo em busca da satisfação de outros desejos. A perda de confiança em si mesmo também é refletida no mundo externo, a ponto de incapacitar o sujeito para a convivência física com outros seres humanos, seja por sentimento de vergonha, seja por efeitos destruidores sobre sua estrutura psíquica. A incapacidade do sujeito em fazer valer suas vontades, como é o caso em situações de tortura, estupro ou de violência

\footnotetext{
${ }^{128}$ Honneth,2003.
} 
física em geral é acompanhado por uma profunda sensação de incapacidade. Além da dor da violência, o fato do sujeito não dispor mais da vontade sobre seu corpo o coloca em situação de fragilidade e sujeição a outro externo com o qual não desenvolve relações positivas.

Da mesma forma que as relações amorosas, estas formas de desrespeito por meio da dominação corporal não apresentam historicidade, pois atuam sobre a formação psíquica da pessoa e sobre a sua relação com o mundo social e não sobre as relações possíveis de desenvolvimento em determinada situação histórica. No entanto, seu caráter patológico não pode ser negado, visto que o amor representa o pré-requisito para que os sujeitos possam desenvolver qualquer outro tipo de relação social. A perda de confiança no mundo social e em si mesmo torna o sujeito que sofre com esta relação incapaz de desenvolver de maneira completa os sentimentos de participação social em qualquer situação.

O segundo tipo de relação de desrespeito ocorre por uma denegação de direitos, ou seja, é negada ao sujeito a condição de igualdade para com outros membros da comunidade de que faz parte. Essa relação negativa acarreta na perda do auto-respeito. ${ }^{129} \mathrm{O}$ sujeito excluído passa a ter um entendimento negativo sobre suas próprias capacidades morais, ou seja, sobre sua igualdade em relação a outro externo generalizado. Provoca também uma sensação de incompletude, visto que os direitos à realização completa de sua identidade são negados. A exclusão da norma moralmente universalizada coloca o indivíduo em uma situação de imputabilidade moral atribuída aos outros que lhe é negada, ele aparece como um ser inferior aos olhos dos outros, como alguém que não merece ser alçado ao papel de parceiro de interação de mesmo nível. A privação do direito, no entanto, ao contrário da privação da autonomia, varia historicamente em função de formas sociais consideradas moralmente imputáveis, quanto no que se refere à universalidade destes direitos, tanto no que se refere a sua garantia material.

O terceiro tipo de desrespeito corresponde ao rebaixamento do valor social do indivíduo de um grupo. Essa determinação negativa está ligada a formas de preconceito e a hierarquização de tradições e horizontes culturais valorativos que põem em riso a capacidade de auto-realização de outros indivíduos, impedem estes de atribuírem valor social a si mesmos, de modo que eles percam a auto-estima que lhes permite

\footnotetext{
${ }^{129}$ Honneth,2003.
} 
perceberem-se como socialmente queridos em suas particularidades ${ }^{130}$. Os indivíduos são levados a crer que suas particularidades não possuem qualquer significação positiva dentro da comunidade e, por isso, seus padrões mesmos de auto-realização não merecem o devido valor, aquele atribuído por ele a si mesmo.

As privações e denegações funcionam como ameaças à identidade do sujeito e à sua vida social. As experiências emocionalmente negativas formam a base motivacional para as lutas por reconhecimento, são sentimentos catalisadores da percepção, maneira privilegiada do sujeito obter percepção de negação do reconhecimento injustificado. Isto por que a formação depende do reconhecimento dos parceiros de interação. Uma vez que este lhe é negado, diz Honneth, ocorre em sua personalidade uma "lacuna psíquica", bem como uma reação ativa a essas lacunas:

para chegar a uma auto-relação bem sucedida, ele depende do reconhecimento intersubjetivo de suas capacidades e suas realizações; se uma tal forma de assentimento social não ocorre em alguma etapa de seu desenvolvimento, abre-se na personalidade como que uma lacuna psíquica, na qual entram as reações emocionais negativas como a vergonha e a ira. Daí a experiência de desrespeito estar sempre acompanhada de sentimentos afetivos que podem revelar ao indivíduo que determinadas formas de reconhecimento lhe são socialmente denegadas. $^{131}$

A lacuna psíquica (sentimento de desrespeito) joga o indivíduo em situação de vergonha social, a situação de desrespeito lança o indivíduo em uma situação de vergonha social que na forma de uma luta por reconhecimento reage contra a situação de opressão imposta por outros membros. Dessa forma "as reações negativas que acompanham no plano psíquico a experiência de desrespeito podem representar de maneira exata a base motivacional afetiva na qual está ancorada a luta por reconhecimento"

\footnotetext{
${ }^{130}$ Honnth,2003.

${ }^{131}$ Honneth, 2003, pág. 220.

132 Honneth,2003, pág.219-20.
} 
Assim, portanto, segundo Honneth, uma sociedade moralmente justa, pautada pelo princípio do reconhecimento depende da capacidade de reagir a situações de desrespeito. O caráter empírico da teoria social de Honneth é baseado na percepção de que o desrespeito é uma prática social. Assim, portanto, a solução para situação de desrespeito, de vergonha e rebaixamento que impede a ação social dos indivíduos deve ser realizada também sob a forma de uma prática social, ou seja, através de uma luta por sua realização. Assim, enquanto a prática social de uma luta se contrapõe à situação patológica de desrespeito, o conteúdo prático daquela luta, o reconhecimento contém uma norma de resistência justamente porque seus conteúdos normativos trazem à tona a moralidade desfeita na relação de desrespeito:

Simplesmente porque os sujeitos humanos não podem reagir de modo emocionalmente neutro às ofensas sociais, representadas pelos maus-tratos físicos, pela privação de direitos e pela degradação, os padrões normativos do reconhecimento recíproco têm uma certa possibilidade de realização no interior do mundo da vida social em geral; pois toda realização emocional negativa que vai de par com a experiência de um desrespeito de pretensões de reconhecimento contém novamente em si a possibilidade de que a injustiça infligida ao sujeito se lhe revele em termos cognitivos e se torne motivo de resistência política. ${ }^{133}$

Ao definir empiricamente a estrutura da tipologia negativa das formas de reconhecimento, Honneth garante a capacidade de resistência dentro da esfera moral de ação. E garante dessa forma a segunda tarefa atribuída a Teoria Crítica por Horkheimer. A luta por reconhecimento é definida como a força moral por trás do movimento histórico, corresponde a estrutura contida nos conflitos sociais. Os " movimentos sociais", dessa forma, são interpretados estruturalmente como movimentos que contestam uma estrutura social hierárquica e desrespeitosa para com determinados grupos sociais. A realização da moralidade desfeita não é uma necessidade discursiva ou motivação direta dos movimentos sociais, mas modelo explicativo dos processos de mudança social.

\footnotetext{
${ }^{133}$ Honneth,2003, pág.224.
} 
No entanto o entendimento estrutural das lutas social como decorrentes das demandas morais permanece pouco claro. O conceito de intersubjetividade vinculante não é suficiente para garantir a formação de movimentos de contestação. Desta maneira, um próximo passo para análise sobre a obra de Honneth deve se pautar pela avaliação de sua relação com as lutas sociais, mais especificamente sua validade enquanto modelo imanente e transcendente para a realização daquele conteúdo moral por ele identificado.

\section{LUTA POR RECONHECIMENTO: A LÓGICA MORAL DOS CONFLITOS SOCIAIS}

\subsection{Ampliação do Social}

Para Honneth, a compreensão da lógica, ou gramática do surgimento e configurações dos movimentos sociais só é possível através da explicação da dinâmica das experiências morais subjacentes aos conflitos sociais. Assim, portanto, Honneth deve explicar como o desrespeito se transforma em resistência e quais os fundamentos normativos ligados à constituição dos movimentos sociais. No diálogo que realiza com Marx, Sartre e Sorel, ele tenta mostrar o potencial semântico do vocabulário conceitual do reconhecimento, e mostrar que este, enquanto força moral, promove $\mathrm{o}$ desenvolvimento e o progresso na realidade social do ser humano.

Esses autores, segundo Honneth, em oposição a Hobbes e Maquiavel, representam o exemplo mais significativo de um conceito social de pensamento da filosofia social que pensou os conflitos sociais a partir do reconhecimento. Para ele, o pensador que primeiramente mais se inspirou na redefinição da luta social de Hegel foi Karl Marx, com sua teoria da luta de classes. Georges Sorel, por sua vez, lutando contra o estreitamento economicista do marxismo tentou pensar as transformações históricas como frutos de uma luta por reconhecimento. E, por último, Jean Paul Sartre tornou fecunda a idéia de uma luta por reconhecimento para a elaboração teórica de uma teoria social com pretensões críticas. Apesar de todo esforço e tentativa, para Honneth esses pensadores, no entanto, sempre consideraram parcialmente os aspectos morais do reconhecimento, tendo em vista uma das suas três formas que Hegel já havia distinguido. Assim, mostrou-se a eles uma impossibilidade de sistematização razoável 
de uma teoria social baseada no reconhecimento, o que não os impediu, de acordo com Honneth, de formar uma tradição de interpretação acerca dos seus fenômenos.

Para Honneth os três pensadores apresentaram ao modelo da luta por reconhecimento novas ideias e ampliações. Marx tornou claro o conceito de trabalho com medium possível de reconhecimento recíproco, Sorel evidenciou a importância dos sentimentos coletivos de desrespeito infligido, e Sartre, com seu conceito de neurose, pode abrir caminho para a noção de patologia das relações de reconhecimento. No entanto, embora tenham feito bom uso em termos empíricos, nenhum pode concluir sistematicamente o desenvolvimento da tese da luta por reconhecimento proposta por Hegel e aprofundada pela psicologia social de Mead, já que as implicações e pressuposto destas ficaram como que reduzidas ou confundíveis em suas filosofias. $\mathrm{O}$ mesmo aconteceu com os grandes pensadores sociais como Durkheim, Weber ou Simmel, os quais, de uma forma ou de outra, acabaram por sucumbir ao modelo hobbesiano de luta por interesses. ${ }^{134}$

Após seguir os traços da tradição do paradigma do reconhecimento tal como proposto por Hegel e aprofundado por Mead, bem como atentar para as novas tendências da historiografia, Honneth esboça uma primeira definição de luta social. Para ele uma luta só pode ser tida como "social" na medida em que é capaz de suscitar objetivos que se tornem coletivos, ou seja, quando eles podem se generalizar a ponto de tornar possível um movimento coletivo. A luta social, seria:

(...) o processo prático no qual experiências individuais de desrespeito são interpretadas como experiências cruciais típicas de um grupo inteiro, de forma que elas podem influir como motivos diretores da ação, na exigência coletiva por relações ampliadas de reconhecimento. ${ }^{135}$

Ainda no escopo do esclarecimento do conceito de luta social Honneth distingue entre lutas morais e lutas por interesse, qualificando a luta por sobrevivência econômica como luta por interesses. No entanto, aqui, essa distinção parece um tanto quanto ambígua. Honneth primeiro esclarece que nem todas as lutas sociais necessariamente são originadas por experiências morais. Isto porque algumas podem realmente ser

\footnotetext{
${ }^{134}$ Honneth, 2003.

135 Honneth, 2003, p.257.
} 
motivadas por interesses coletivos de conservação ou de poder, como historicamente já se deu, segundo ele, com as lutas por sobrevivência econômica, as quais já levaram grandes massas a rebelião e protestos. "Interesses são orientações básicas dirigidas a fins, já aderidas à condição econômica e social dos indivíduos pelo fato de que estes precisam tentar conservar pelo menos as condições de sua reprodução."136 Para Honneth, lutas por estes interesses dizem respeito à conscientização dos sujeitos quanto à impossibilidade própria da sua situação em manter os seus objetivos de reprodução. Em contraste com este tipo de luta, as lutas originadas por sentimentos de desrespeito, o que está em cheque são as condições da integridade psíquica dos sujeitos. "Ali se trata da análise de uma concorrência por bens escassos, aqui, porém, da análise de uma luta pelas condições intersubjetivas da integridade pessoal" "137. Diante do exposto, Honneth afirma que seu modelo não é capaz de substituir o modelo chamado por ele de utilitarista, mas sim complementar, visto que sempre seria para ele "uma questão empírica saber até que ponto um conflito social segue a lógica da persecução de interesses ou a lógica da formação moral" ${ }^{138}$. No entanto, logo à frente, em referência aos estudos do historiador Edward P. Thompson, ele volta à questão das lutas originadas por privação econômica e experiências da miséria, afirmando, em relação a Thompson:

Thompson se deixou guiar pela idéia de que a rebelião social nunca pode ser apenas uma exteriorização direta de experiências da miséria e da privação econômica; ao contrário, o que é considerado um estado insuportável de subsistência econômica se mede sempre pelas expectativas morais que os atingidos expõem consensualmente à organização da coletividade. Por isso, o protesto e a resistência prática só ocorrem em geral quando uma modificação da situação econômica é vivenciada como uma lesão normativa desse consenso tacitamente efetivo. $^{139}$

\footnotetext{
${ }^{136}$ Honneth,2003, pág. 260.

${ }^{137}$ Honneth,2003,pág.261

138 Honneth,2003,pág. 261

${ }^{139}$ Honneth,2003,pág. 263.
} 
Neste trecho, Honneth deixa entrever que as lutas por interesse, desde que criticamente relacionadas ao consenso normativo "tacitamente" efetivo de uma sociedade ou grupo, isto é, ao contexto moral e social de cooperação que implicitamente existe e dá regulamentação informal aos modos de relação internos da comunidade, devem ser entendidas como lutas morais. Assim a violação do consenso moral implicitamente constituído, seria uma experiência em que o próprio reconhecimento social dos sujeitos seria denegado, e isto, como agravante, por que afetaria também sua própria identidade pessoal ou coletiva. O rompimento do consenso normativo, que de certa maneira regula as relações de reconhecimento mútuo, seria vivenciado como ataque às identidades e, consequentemente, como impossibilidade de constituição do auto-respeito coletivo, o que, por seu turno, seria causa de resistência política e revoltas sociais.

Apesar dessa ambiguidade, os estudos históricos realizados por Honneth o levam à constatação da insuficiência das análises dos confrontos sociais pautados pelas exigências de reconhecimento. Para ele esses confrontos ocupariam um espaço muito pequeno para que fosse possível a explicação, em seu todo, do desenvolvimento moral da sociedade: "os resultados expostos, sejam revoltas espontâneas, greves organizadas ou formas passivas de resistência, mantêm sempre alguma coisa de caráter apenas episódico (...)"140. Para contornar essa limitação, Honneth, então, passa a tomar a lógica da ampliação das relações de reconhecimento também como paradigma das transformações históricas. Somente a partir dessa perspectiva que se torna possível a percepção e avaliação do processo de evolução moral das sociedades:

as lutas e conflitos históricos, sempre ímpares, só desvelam sua posição na evolução social quando se torna apreensível a função que eles desempenham para o estabelecimento de um progresso moral na dimensão do reconhecimento. ${ }^{141}$

\footnotetext{
${ }^{140}$ Honneth, 2003, pág.

${ }^{141}$ Honneth, 2003, pág. 265.
} 
Essa mudança de direção, na qual o seu modelo de conflito passa a ser encarado também como paradigma de interpretação de um processo formativo que obedece a lógica universal das ampliações de reconhecimento, requer também uma mudança no objeto de investigação da teoria do reconhecimento. As formas de desrespeito moral devem ser analisadas também em relação " ao papel que lhes deve competir em cada caso no desdobramento das relações de reconhecimento"142. No entanto, para que os sentimentos de injustiça social sejam avaliados segundo suas funções ampliadoras ou não do desenvolvimento mais abrangente do reconhecimento, Honneth acredita ser necessário a antecipação de um ponto final hipotético de uma ampliação das relações de reconhecimento. Somente assim seria possível obter um critério de avaliação de progressos e retrocessos contidos nas reivindicações das lutas históricas e em direção ao reconhecimento.

Esse ponto final hipotético, segundo Honneth, consiste em um quadro interpretativo explicativo, resultado da projeção de um processo de formação moral a partir de uma sequência idealizada de lutas nas quais o potencial normativo da categoria do reconhecimento seria desdobrado. Esse quadro seria caracterizado inicialmente, de acordo com as formulações de Hegel e Mead e a atualização de Honneth, pelo entrelaçamento dos três padrões de reconhecimento: do amor, do direito e da estima. Essas formas de reconhecimento garantidoras das auto-relações práticos saudáveis que propiciam aos sujeitos a possibilidade de se perceberem como seres autônomos e individuados se encontrariam conectadas indistintamente numa situação de interação social, isto é, num contexto sócio-cultural em que os direitos dos membros da comunidade não estariam definidos separadamente dos aspectos de assistência e da estima social $^{143}$. A distinção das três formas de reconhecimento marcaria, portanto, o momento em que a percepção do potencial inscrito nas mesmas, ou seja, passa a ser tangível a potencialidade evolutiva específica de cada dimensão singular do reconhecimento, assim como os múltiplos modos de luta próprios de cada dimensão.

Assim, para que seja possível a compreensão dos acontecimentos históricos como componentes de um processo maior, em que o conflito conduz ao aumento gradual do caráter das relações de reconhecimento, Honneth precisa descrever o caminho hipotético pelo qual se desenvolveram as potencialidades do direito moderno e

\footnotetext{
142 Honneth, 203, pág. 265.

143 Honneth,2003.
} 
da estima social. Somente com esse procedimento, é possível determinar o critério normativo pelo qual se poderia avaliar a significação das lutas particulares quanto à positividade ou não delas no que concerne à realização saudável das formas do reconhecimento. Por isso, Honneth precisa estabelecer sistematicamente qual seria o ponto final hipotético em que se constituiria "um estado comunicativo em que condições intersubjetivas da integridade pessoal aparecem como preenchidas" ${ }^{" 144}$. Para tanto, ele pretende então se utilizar do conceito de eticidade tal como já havia proposto o jovem Hegel, contendo as condições intersubjetivas para a constituição da integridade pessoal, só que de feitio atualizado numa forma dessubstancializada.

\subsection{Eticidade Formal}

Antes de estabelecer o significado da concepção formal de eticidade, Honneth esclarece o status metodológico do conceito. Honneth não pretende justificá-lo metodologicamente a partir de critérios de avaliação moral da tradição relativa ao universalismo formal que remete a Kant, mas sim reaver a importância da filosofia social de Hegel a qual concebe a validade dos princípios morais admitidos na forma de vida ética historicamente situada. Antes, no entanto, de buscar acirrar a divergência entre essas duas correntes, Honneth pretende recuperar a importância de aspectos universalistas que deve conter uma teoria que trate das possibilidades de constituição da vida boa.

Segundo Honneth, as correntes da filosofia social que se opõem à tradição Kantiana criticam o caráter abstrato de seu conceito de moralidade, "contra a tradição kantiana, é levantada a objeção de que ela deixa sem resposta uma questão decisiva, visto que não é capaz de identificar o fim da moral em seu todo nos objetivos concretos dos sujeitos humanos". 145 Honneth, no entanto, não fornece uma concepção historicamente determinada de vida boa em detrimento dos princípios universalistas definidos abstratamente, propondo assim uma nova inversão da relação entre moralidade e eticidade. Para ele, isso acarretaria validar mais uma vez a oposição moralidade/eticidade, o que, definitivamente, não é seu intento.

\footnotetext{
${ }^{144}$ Honneth, 2003, pág. 268.

${ }^{145}$ Honneth,2003, pág. 270.
} 
Para Honneth, a Teoria do reconhecimento deve ser situada entre a teoria moral da tradição kantiana e as éticas comunitaristas. Não se enquadra, por um lado, na tradição kantiana, visto que além das condições de autonomia do ser humano, busca garantir as condições da auto-realização dos sujeitos como um todo. A moral é concebida como mera concretização do objetivo universal de uma vida boa. Por outro lado, se afasta da tradição comunitarista, visto que a noção de bem não é concebida a partir de uma axiologia particular ou substancial relativa à tradição de comunidades singulares, mas a partir de um ponto de vista universal da possibilidade comunicativa da auto-realização e também pelo interesse em normas universais de comportamento.

Para que, portanto, a teoria do reconhecimento defina relações de reconhecimento pós-tradicionais, diz Honneth, esta deve basear-se no conceito de eticidade que diz respeito ao todo das condições intersubjetivas, enquanto pressupostos normativos, pelas quais se chega à autorrealização individual. As concepções axiológicas concretas não devem ser buscadas a partir de mundo concreto da vida particular, mas de determinações formais ou abstratas da vida boa tendo em vista esses contextos interpretativos particulares; do ponto de vista do conteúdo, por sua vez, será guardador de um teor específico que faça valer as condições da autorrealização mais satisfatoriamente do que a noção kantiana de autonomia individual.

Honneth, através de uma noção de liberdade retoma a ideia de que a constituição da auto-realização individual depende da experiência do reconhecimento, ou seja, processo de realização espontânea.

Sem a suposição de uma certa medida de autoconfiança, de autonomia juridicamente preservada e de segurança sobre o valor das próprias capacidades, não é imaginável um êxito na auto-realização, se por isso deve ser entendido um processo de realização espontânea de metas da vida autonomamente eleitas. $^{146}$

Assim, portanto, a concepção de vida boa deve partir do pressuposto do reconhecimento, ou seja, dos seus diversos padrões e formas. O caráter abstrato e formal

${ }^{146}$ Honneth, 2003, pág. 273. 
desses padrões, que dessa forma não incorporam a ideia de modos de vida concreta, garante a universalidade da normatividade proposta por Honneth. As formas de reconhecimento são padrões universais de comportamento, constituem as estruturas dos modos de vida particulares, mas não se confundem com elas. As formas jurídicas de reconhecimento e a própria comunidade de valores contém, por outro lado, o caráter histórico da concepção de vida boa ou eticidade. Estas formas contém em si o potencial de universalidade e igualdade que indicam o estágio histórico como determinante à auto-realização, ou seja, a auto-realização e, portanto, a eticidade depende do nível atual das formas de reconhecimento.

Decorre da discussão acerca do status metodológico do conceito de eticidade formal que as condições intersubjetivas para a integridade da pessoa e para auto-realização surgem sempre por meio do contexto histórico que revela um estágio de desenvolvimento normativo das relações de reconhecimento. Assim, portanto, o conceito de eticidade formal depende da situação histórica dos três poderes de reconhecimento que guardam em si um potencial de ampliação.

No que diz respeito ao seu conteúdo, a forma de reconhecimento do amor corresponde à primeira condição para a consolidação da integralidade. Embora possua forma atemporal, constitui condição para outras formas de auto-realização. A relação afetiva é tão elementar que está presente em todas as formas de vida consideradas éticas, assim no conceito pós-tradicional de eticidade ela assume a forma atemporal. Através do reconhecimento afetivo que o sujeito garante auto-confiança que o capacita para todos os outros tipos de auto-realização futura. O conceito de eticidade formal salvaguarda o igualitarismo radical do amor contra as formas de negação dessa dimensão.

A relação jurídica constitui a segunda condição necessária para consolidação da integralidade. Contém potencial moral, desenvolvido através de lutas sociais, que permite a aplicação generalizada e da materialização. $O$ reconhecimento jurídico constitui condição de autonomia moral. Somente o asseguramento dos direitos concernentes à liberdade individual que o sujeito pode dirigir a própria vida de forma particular, da maneira como desejar, isto é, sem coerção ou influência exterior a si. Para Honneth, Hegel e Mead, reduziram a relação jurídica a simples existência de direitos liberais de liberdade, sem se ater às condições de aplicação. Ignoram dessa forma os 
potenciais de desenvolvimento e ampliação tanto em direção à universalidade, quanto à materialização. A relação jurídica possui, no contexto do conceito de eticidade tradicional, status singular. Ela influi nas outras duas formas de reconhecimento, ou seja, no amor e solidariedade. Por outro lado assegura condições físicas elementares dos sujeitos que garante autonomia moral necessária a solidariedade social.

A solidariedade, terceira condição necessária para o asseguramento da autorealização e integridade pessoal, só pode ser entendida a partir da perspectiva das relações jurídicas e seu nível de reconhecimento dado em determinada situação histórica. A relação de solidariedade é desenvolvida no âmbito de uma comunidade de valor, categoria que permite um alcance mais amplo do que a estima social. O horizonte de valor que determina a auto-compreensão de comunidade que garante as possibilidades e potenciais de equalização e individualização dessa forma de reconhecimento. Revela também a dependência das condições morais das relações jurídicas do momento, ou seja, ligação às condições estabelecidas da autonomia individual dos sujeitos.

Para Honneth, embora Hegel e Mead tenham previsto a simetria da situação de estima entre pessoas de direito, não alcançam a questão do conteúdo dessa solidariedade, ou seja, a condição material que permite a abertura da pluralidade.

Ambos, Hegel não menos que Mead, não atingiram o objetivo, estabelecido por eles mesmos, de determinar um horizonte abstrato de valores éticos, aberto às mais distintas metas de vida, sem perder a força solidarizante da formação coletiva da identidade $^{147}$.

Para Honneth, somente uma eticidade formal esboçada pela teoria do reconhecimento, no qual valores materiais são introduzidos com as formas de reconhecimento é capaz de garantir as condições de formação de uma solidariedade póstradicional que explique as possibilidades de auto-realização variadas e múltiplas.

Assim no delineamento de "Luta por Reconhecimento", Honneth propõe uma elucidação categorial da realidade social que perpassa a teorização acerca de fontes da experiência que sejam "interiores” às próprias práticas sociais, caracterizadas pela ideia

\footnotetext{
${ }^{147}$ Honneth, 2003 pág. 280.
} 
de reconhecimento. É a partir deste conceito que Honneth pretende sustentar, por um lado, uma crítica do "déficit sociológico" e, por outro lado, tratar a integração social como uma questão normativa. Para Honneth a realidade social é estruturalmente constituída por esferas sociais do reconhecimento a partir das quais ele pode extrair os critérios normativos para sua Teoria do Reconhecimento e da justiça. Honneth situa o conflito social e os sentimentos de desrespeito e injustiça no centro da Teoria Crítica. As patologias sociais são interpretadas como fenômenos negativos advindos do interior mesmo das práticas e estruturas sociais que são concebidas de modo a compor o núcleo gerativo das ações e da possibilidade dos processos de formalização e institucionalização.

A partir do conceito de reconhecimento, Honneth pode conceber uma teoria da formação da personalidade que o permite tratar a integração social a partir de um viés normativo. A formação bem sucedida da personalidade constitui o fundamento normativo do reconhecimento que os indivíduos esperam receber, isto porque esta formação ocorre por meio de conflitos intersubjetivos que, quando socializados, passam a ser conflitos entre grupos pela obtenção de reconhecimento de suas especificidades.

Honneth está preocupado com a integridade da personalidade individual que se forma em meio a processos sociais e com sua contrapartida negativa, o desrespeito. Estas duas relações, reconhecimento e desrespeito, são tomadas por Honneth como sentimentos que decorrem da existência de auto-relações que, por sua vez, se desenvolvem através de relações sociais, que são responsáveis tanto pela formação de expectativas normativas e sentimentos individuais quanto de sentimentos de desrespeito e opressão. Honneth parte da formulação materialista das formas elementares do convívio e experiência intersubjetivas, passa pelas estruturas das relações sociais, chega à elaboração das formas de desenvolvimento e evolução sociais baseadas no reconhecimento e finalmente fornece um padrão normativo de avaliação das lutas sociais, por meio de um conceito formal de eticidade. Com isso, ele amplia a conceituação do social e suas esferas, ao derivar das formas elementares da interação o âmbito da estrutura e gramatica moral dos conflitos sociais.

Embora a teoria retire sua dimensão normativa das demandas dos sujeitos pelo seu reconhecimento, esta também abarca as esferas de produção cultural e institucionalização da participação social. Uma vez que a formação da personalidade completa passa pelo reconhecimento do mundo social, as demandas morais por 
reconhecimento tem por efeito a ampliação das relações de reconhecimento. A teoria do reconhecimento prevê uma passagem de uma formação intersubjetiva para lutas pelo reconhecimento coletivo de diferentes valores éticos. Honneth procura com seu modelo atualizar a ideia hegeliana de um sistema de eticidade ao mesmo tempo em que procura abarcar, as esferas individuais e sociais do desenvolvimento pessoal. O sentido crítico desta teoria seria então o de observar na relação entre as expectativas normativas dos indivíduos e as estruturas de integração a possibilidade de superação de situações de desrespeito e a construção de um sistema de eticidade.

A teoria do reconhecimento de Honneth, então, procura transformar o modelo habermasiano da teoria da comunicação consensual em uma teoria intersubjetiva do conflito pela integração e pelo reconhecimento de demandas morais de grupos de indivíduos, tanto por meio de demandas positivas quanto por meio de conflitos pela superação de situações de reconhecimento denegado. Nesta proposição nota-se que a dimensão psíquica do conceito de reconhecimento possui uma relação formal com os motivos de ação. Esta relação é sintetizada na ideia de que as expectativas normativas do sujeito quanto à sua identidade são os motivos para a luta por reconhecimento quando desrespeitadas. Mais importante, contudo, é o fato de que estas expectativas dizem respeito à participação dos sujeitos na vida comunitária, de modo que a dimensão psíquica normativa possui um reflexo sobre as organizações sociais existentes ou, pelo menos, sobre as demandas das lutas sociais por esta organizada. Esta é a solução que Honneth parece ter encontrado, em um primeiro momento, para a superação do "déficit sociológico" da teoria crítica. Assim a teoria do reconhecimento proposta em sua teoria busca critérios ético-normativos internamente ao mundo social com vista a atacar os problemas normativos de ordenação e conflito entre atores envolvidos nessas lutas, os processos de formação de demandas por reconhecimento funcionam como impulsos para dinâmica histórica de ampliação das relações de reconhecimento. Honneth elabora uma teoria da relação entre formação intersubjetiva e horizonte normativo, entre teoria normativa e sociologia.

Honneth propõe um tipo de análise do conflito em que tanto a dimensão formativa individual quanto a dimensão interativa da identidade se relacionam ao estabelecimento de padrões normativos de socialização que, por sua vez, remetem à relação entre estes processos. Há na perspectiva honnetiana uma espécie de dialética positiva entre reconhecimento e a diferenciação de identidades que leva àquela 
ampliação das relações de reconhecimento. $\mathrm{O}$ especificamente sociológico da teoria do reconhecimento decorre do que Honneth chama de um processo de lógica moral de ampliação das relações de reconhecimento. A expansão das instituições reguladoras da sociedade resultaria segundo Honneth dos conflitos sociais pelo reconhecimento da identidade ou pelo processo de integração social formada intersubjetivamente. Ou seja, a interação social e a luta por reconhecimento estariam intimamente ligadas e sua articulação se daria em torno de concepções de bem estar individual e coletivo reconhecidas por outros membros da sociedade nas esferas jurídica e da solidariedade. Assim o especificamente sociológico da teoria do reconhecimento pode ser associado ao estabelecimento de um padrão normativo de socialização no qual a relação entre interação e ampliação dos padrões de reconhecimento fosse garantida.

De acordo com a proposta de Honneth, portanto, uma integração social justa é aquela que respeita a diferença e a abriga como positiva ao mesmo tempo em que vê as lutas sociais como elementos fundamentais da ampliação desta aceitação. O modelo que Honneth defende é o de uma reatualização da noção hegeliana de eticidade. Com a reformulação do conceito de eticidade ao final de Luta por Reconhecimento, Honneth pretende não só dar uma justificativa prática para as lutas por reconhecimento, mas também demostrar como a ideia de uma rede de reconhecimento sustentada pelo reconhecimento jurídico universalmente assegurado e pela garantia das possiblidades de obter estima social pode ocupar lugar de um horizonte emancipatório como aquele imaginado por Horkheimer. Para explicar como as lutas que têm conscientemente orientado os movimentos sociais desde a emergência do capitalismo devem ser enquadradas em uma teoria do reconhecimento, Honneth precisa, pois, estabelecer uma ligação entre seu padrão avaliativo de uma evolução moral da sociedade e um conceito de justiça como horizonte organizativo da ação social. Essa parece ser a tarefa proposta por Honneth em Sofrimento de Indeterminação, o autor volta à filosofia hegeliana, agora com intenções de reatualizar a "doutrina da eticidade" de Hegel presente na Filosofia do Direito. É essa etapa do seu empreendimento que será discutida no próximo capítulo. 


\section{PARTE III: TEORIA DA JUSTIÇA COMO ETICIDADE}

\section{TEORIA DA JUSTIÇA COMO ETICIDADE}

\subsection{Filosofia do Direito como Teoria da Justiça}

Em "Sofrimento e Indeterminação"148, Honneth propõe uma reatualização da Filosofia do Direito de Hegel, com vista a obter uma teoria da justiça que além de superar o debate contemporâneo entre liberais e comunitaristas deve ser compatível com sua teoria do reconhecimento e que dessa forma permita a realização da tarefa crítica de imanência e transcendência. Honneth aposta em uma teoria da justiça que ao mesmo tempo em que rivaliza com Rawls, constitui continuidade do redirecionamento da teoria social de Habermas. Somente uma reconstrução normativa da teoria da justiça baseado indiretamente nos conceitos de filosofia do direito hegeliano, diz Honneth, seria capaz de sinalizar os bloqueios e potenciais inscritos nas sociedades modernas para realização completa da liberdade.

Assim, portanto, o debate contemporâneo sobre a fundamentação de uma teoria de justiça política e social que seja moralmente justificável é marcada pela disputa entre liberais, cujas normas moralmente justificadas são transcendentes ao contexto; e comunitaristas, cujas normas consideradas justas são imanentes aos contextos. Já em luta por reconhecimento Honneth havia indicado a incompatibilidade de sua teoria com a tradição que remete Kant, sua teoria " desvia-se da tradição que remonta a Kant porque se trata para ela não somente da autonomia moral do ser humano, mas também das condições de auto-realização como um todo". ${ }^{149}$ Para ele a moral constitui um meio que serve a um fim universal da realização da vida boa, ou seja, a ampliação da moralidade é orientada em direção a eticidade. Daí a pertinência da "reatulização" da filosofia de Hegel, visto que em Hegel se encontra uma crítica contundente ao modelo abstrato Kantiano de auto-realização individual baseado na autonomia moral. Honneth opõe ao construtivismo Kantiano da teoria da justiça de Rawls a sua teoria normativa da justiça baseada nos conceitos elementares da filosofia do direito de Hegel. Por estar vinculado a uma tradição crítica, Honneth deve conceber uma teoria de justiça que

\footnotetext{
${ }^{148}$ Honneth,2007.

${ }^{149}$ Honneth,2003, pág. 271.
} 
forneça um diagnóstico crítico sobre as patologias sociais da nossa época a fim de apontar para a superação dessas patologias, intenção que, segundo ele, não se encontra na teoria rawlsiana. Assim, portanto, Honneth busca construir uma teoria da justiça, que permita a relação entre uma perspectiva universalista, mas que esteja ancorada na ordem social através dos instrumentos conscientes oferecidos pela filosofia do direto Hegeliano.

(...) o propósito de fundamentar uma teoria da justiça está vinculado à perspectiva da teoria crítica, em que se trata de fornecer um diagnóstico do tempo, ou seja, o diagnostico do "sofrimento de indeterminação" como uma patologia que resulta da realização incompleta ou insuficiente da vontade livre em âmbitos institucionais da sociedade moderna não estruturados conforme a eticidade. ${ }^{150}$

A partir da reatualização da filosofia do direito de Hegel, Honneth pode reconstruir as práticas e as condições do reconhecimento das sociedades modernas. Para ele uma teoria da justiça deve proteger os contextos do reconhecimento recíproco, porque somente assim a liberdade em toda a sua extensão pode adquirir condições de concretização, isto é, condições de realização da vida boa. A reatualização, no entanto, não se dá sem dificuldades. Honneth deve evitar o conceito antidemocrático do Estado e também as implicações da fundamentação metafísica constitutiva da lógica do pensamento hegeliano. ${ }^{151}$ Essa tarefa é realizada indiretamente. Isto é, Honneth não reconstrói o texto integramente, mas duas categorias que para ele são centrais para a mediação das questões de justiça que constituem seu interesse: "objektiver Geist" (espírito objetivo) e "Sittlichkeit" (eticidade). A interpretação da obra hegeliana visa, portanto, alcançar os fundamentos dos princípios normativos de justiça a partir do contexto das condições necessárias para a auto-realização individual, e não apenas de uma dedução formal.

O princípio da liberdade individual para todos os sujeitos é, portanto, a preocupação central de Honneth. Isso fica expresso na definição que toma de Hegel "O fato de que um ser-aí em geral seja ser aí (Daisein) da vontade livre, isso é o direito" ${ }^{152}$. O direito é o ser aí ou existência da vontade livre. Este conceito é entendido dentro do

\footnotetext{
${ }^{150}$ Werle,D,L e Melo,R.S. “ Teoria Crítica, teorias da justiça e a 'reatualização' de Hegel”. In: Honneth,A. Sofrimento de Indeterminação: uma Reatualização da Filosofia do Direito de Hegel.2007, Pág. 44. ${ }^{151}$ Honneth, 2007, pág, 48-49.

152 Hegel, 2005, § 29, pág.68.
} 
contexto do "espírito objetivo", isto é, o direito tem que ser visto como concernente ao quadro dos costumes, leis, práticas e instituições de determinada época e povo; ele fundamenta-se na experiência do espírito comum de um povo ou ordem social cuja manifestação exprime o caráter e as consciências dos seus indivíduos. O espírito objetivo é então uma importante categorização do sistema hegeliano para caracterização da Modernidade. A razão moderna só pode efetivar-se enquanto liberdade. Assim a filosofia do direito deve se ater as condições sociais da realização da vontade livre universal $^{153}$. A tarefa deve ser buscar as condições da existência da vontade livre em uma ordem social justa. Já na introdução da "Filosofia do Direito" Hegel critica as idéias modernas de vontade livre.

Hegel enxerga no pensamento filosófico duas concepções incompletas de autodeterminação individual. Na primeira a autodeterminação é concebida como liberdade negativa ou "indeterminidade", limitação da liberdade individual, caracterizada como distanciamento das carências, desejos e impulsos. Embora seja para ele elemento fundamental da liberdade, tem como resultado a perda da ação. A segunda é concebida como liberdade de escolha ou de decisão refletida entre conteúdos dados, o momento da "determinidade" o qual já estava contido no primeiro momento negativo, e no qual se encontram os princípios da filosofia moral tanto kantiana quanto fichteana. A limitação desta última concepção de auto-determinação individual consiste em que ela só pode tomar a liberdade da vontade individual como deliberação moral acerca dos impulsos ou inclinações, trata-se para Honneth de um modelo "optativo" de "vontade livre". O material da decisão refletida da vontade será sempre contingente ou "heterônomo", ou seja, a vontade "finita" apenas "formalmente" é infinita.

Para Hegel o defeito desse segundo modelo, o optativo, reside em ter de representar o ato de autodeterminação incondicionalmente como uma escolha refletida entre inclinações ou impulsos da ação por sua vez indisponíveis- e a conseqüência de uma tal determinação imperfeita da liberdade é(...) o dualismo kantiano entre dever e inclinação, entre a lei moral ideal e a natureza meramente externa ao impulso. ${ }^{154}$

Para evitar as insuficiências desses modelos, Hegel pretende desenvolver um modelo complexo de vontade livre. A vontade e aquele conteúdo heterônomo passam a

\footnotetext{
153 Honneth, 2007.

${ }^{154}$ Honneth, 2007,pág. 59
} 
ser compreendidos como resultado da liberdade. Isso implica que a vontade passa a ser concebida como uma relação reflexiva em si, capaz de influir em si mesma, tal como Hegel a entende no $§ 10$, "só quando a vontade tiver a si mesma por objeto ela será para si o que ela é em si"155. Os impulsos e inclinações da vontade passam a constituir conteúdo da liberdade, ou seja, ela tem que querer a si mesma como livre. Para que esses impulsos de ação sejam pensados como livres, ou seja, não-finitos, Hegel, segundo Honneth, passa a interpretá-los a partir do modelo de amizade como ele descreve no parágrafo $\S 7$.

Neles [na amizade e no amor] não se está mais unilateralmente dentro de si, mas cada um [dos relatos] se restringe, de bom grado, em relação a um outro e sabe-se como si mesmo nessa restrição. Na determinidade homem não deve sentir-se determinado, mas ao considerar o outro enquanto outro, ele somente nisso tem o sentimento próprio de si. A liberdade não reside, portanto, nem na indeterminidade, nem na determinidade, senão que ela é ambas ${ }^{156}$.

Nesta formulação, segundo Honneth, Hegel retoma o conceito intersubjetivo de liberdade utilizado por ele no período de Jena em oposição às doutrinas atomísticas do direito natural. A amizade é introduzida como relação característica das formas elementares da intersubjetividade comunicativa e dessa forma juntamente com a liberdade configuram condições de justiça e modelos fundamentais das relações sociais.

Dessa maneira, segundo Hegel, para que possa querer ser livre, a vontade deve ser limitada, em sua expressão e experiência, pelas suas carências, impulsos e desejos; no entanto, sob a condição de que o objeto de sua carência ou inclinação seja livre. $\mathrm{O}$ outro da vontade deve ter essa qualidade para que a liberdade possa ser experienciada. A vontade livre que quer a si como livre consiste, portanto, em uma síntese das duas concepções incompletas de autodeterminação individual. Da concepção optativa, conserva-se o fato de dever ser limitada reflexivamente por uma meta de ação; e da concepção negativa, a forma de uma experiência ilimitada de si mesmo: "A vontade é a unidade desses dois momentos, - a particularidade refletida dentro de si e reconciliada, por meio desta reflexão, à universalidade, - singularidade" ${ }^{157}$. Somente dessa maneira

\footnotetext{
${ }^{155}$ Hegel, 2005,§10.

${ }^{156}$ Hegel, 2005, § 7.

157 Hegel, 2005, § 7 .
} 
a vontade livre pode ser concebida como o "ser consigo-mesmo-no-outro", ou seja, como um modelo comunicativo da liberdade individual.

Segundo Honneth a apresentação da "existência" (Dasein) da "vontade livre", corresponde à apresentação dos pressupostos sociais e institucionais externos necessários à realização da própria vontade. Assim, visto que os sujeitos gozam de liberdade somente quando eles têm condições de participar comunicativamente e integralmente das relações sociais estabelecidas, os pressupostos necessários a efetivação da vontade livre devem também ser entendidos como "o conjunto de uma ordem social justa que permite a cada sujeito individual participar em relações comunicativas que podem ser experienciadas como expressão da própria liberdade"158. Para Honneth, portanto, esses tipos de relações comunicativas elencados por Hegel, podem ser considerados como "bens básicos" o que o permite estabelecer uma oposição a ideia de bem básico em Rawls.

(...) é preciso acrescentar que Hegel, diferentemente de Rawls, não supõe que esse bem básico seja repartido com justiça por meio de alguns princípios; parece que ele visa, na verdade, chegar à ideia de que a "justiça" das sociedades modernas depende da capacidade destas de possibilitar a todos os sujeitos igual participação no "bem básico" de tais relações comunicativas ${ }^{159}$.

Para Honneth, as esferas ou práticas sociais tidas como "bens básicos" caracterizam-se por serem portadoras de direitos, e destinam-se a todos os membros das sociedades (destinatários), distinguidas segundo as condições normativas da autodeterminação individual. Esse tratamento, diz Honneth, configura marca específica da concepção hegeliana do direito: os direitos universais pertencem primeiramente às relações e estruturas sociais, às formas de existência sociais necessárias à realização da vontade livre, constituídas como bens sociais básicos e somente mediatamente eles são remetidas à esfera do indivíduo. Essa é a perspectiva a partir do qual Honneth pretende caracterizar as esferas sociais e concebê-las como núcleo e fundamento das formalizações e institucionalizações societárias.

Para Honneth, portanto, embora Hegel tome como ponto de referência os mesmos princípios normativos da filosofia do direito de Kant e Fichte, em Filosofia do Direito ele não contradiz os seus escritos do período de Jena. A Filosofia do Direito

\footnotetext{
${ }^{158}$ Honneth, 2007, pág. 63.

${ }^{159}$ Honneth, 2007, pág. 63.
} 
constitui a tentativa de desenvolver uma teoria normativa da sociedade que forneça argumentos racionais para legitimar as "pretensões de existência" daquelas esferas e práticas sociais concebidas como "bens básicos" visto que elas são tidas como insubstituíveis quanto à possibilitação social de autodeterminação individual ${ }^{160}$. Os bens básicos das relações comunicativas representam dessa maneira os princípios universais de justiça que permitem aos sujeitos que enxerguem na liberdade do outro a possibilidade de sua própria realização. A Filosofia do Direito constitui dessa forma uma teoria normativa da justiça:

Nesse sentido, a Filosofia do Direito de Hegel representa uma teoria normativa de justiça social que precisa ser fundamentada na forma de uma reconstrução das condições necessárias de autonomia individual, cujas esferas sociais uma sociedade moderna tem que abranger ou dispor para com isso garantir a todos os seus membros a chance de realização de sua autodeterminação. ${ }^{161}$

Para Honneth, a teoria a justiça de Hegel além de reconstruir os pressupostos intersubjetivos da liberdade e autonomia individual, quer também localizar os lugares das diferentes concepções de liberdade na ordem institucional das sociedades modernas. Segundo ele, ainda que esses conceitos exprimam condições insuficientes para a auto-realização, contemplam pressupostos necessários a efetivação da vontade livre, ou seja, da liberdade prática comunicativa. Assim cada esfera (ou concepção) da liberdade, ainda que insuficiente a determinação de todas as condições de realização individual, possuem direitos próprios cujo lugar na estrutura das sociedades modernas constitui condição essencial para sua realização: "cada degrau ou estágio do desenvolvimento da idéia de liberdade tem o seu direito peculiar, porque ele é o ser-aí [Dasein] da liberdade numa de suas determinações próprias" ${ }^{162}$. O "direito abstrato" e a "moralidade" configurariam respectivamente os "lugares" daquelas concepções incompletas de liberdade, a concepção negativa (indeterminidade) e a concepção optativa (determinidade). Enquanto o primeiro constituiria “o lugar social daquelas concepções modernas de liberdade mediante as quais o sujeito individual constrói sua liberdade na forma de direitos subjetivos", o último seria "o lugar legítimo daquelas concepções modernas de liberdade segundo as quais a liberdade do sujeito individual é

\footnotetext{
${ }^{160}$ Honneth, 2007, pág.66.

${ }^{161}$ Honneth, 2007, pág. 67.

162 Hegel, 2005, § 30
} 
caracterizada como a capacidade de autodeterminação moral"163. No entanto, para completar a tripartição da obra, falta o lugar do desenvolvimento das esferas de ação comunicativas, ou seja, a eticidade. Toda obra pode ser explicada ou concebida segundo uma dinâmica interna da vontade livre e suas esferas. Assim, ao direito abstrato opõe-se a moralidade, a qual é sucedida pela eticidade como uma síntese fundamental.

Ao tomar a articulação interna das três concepções de vontade livre contidas na Introdução como chave interpretativa da tripartição da Filosofia do Direito, Honneth, como aludido anteriormente, pretende escapar à necessidade da Lógica do sistema Hegeliano. Segundo ele esse procedimento se justifica por três razões: os três modelos de vontade livre corresponderiam a todas as possibilidades da liberdade no mundo moderno; junto com as práticas sociais, conteriam os caracteres essenciais e necessários à delimitação das relações comunicativas de autodeterminação individual; e por último, os modelos de liberdade não devem ser caracterizados como meras idéias abstratas, mas são como formas do espírito objetivo atuantes no mundo social através dos direitos que lhes competem.

A proposta interpretativa de Honneth do sentido da tripartição da obra fundamenta-se na própria inter-relação interna dos elementos da tripartição. Assim constitui equivoco tanto totalizar uma das esferas da liberdade, como também conferir ao capítulo final sobre a eticidade toda importância na reflexão sobre a obra. Todas as seções servem em conjunto à efetivação do núcleo da teoria da sociedade que Hegel pretende, visto que cada seção corresponde à explicitação dos direitos próprios de cada esfera da liberdade e a eticidade não é simplesmente a soma do todo. No entanto, a absolutização de qualquer uma das formas incompletas da liberdade configura indícios patológicos da própria realidade social. Esse processo leva a "rejeições patológicas na própria realidade social que são um indicador preciso e 'empírico' de que os limites do âmbito de validade legítimo foram transgredidos" ${ }^{164}$. A relação necessária entre situações patológicas e absolutização dos dois modelos incompletos de liberdade constitui a base da tese hegeliana na qual a realidade social é afetada em virtude da aplicação de determinações falsas e insuficientes da existência humana visto que ela própria é formada em função dos fundamentos racionais ditados pela mesma razão, assim, a violação prática de tais fundamentos acarreta a violação do próprio mundo social.

\footnotetext{
${ }^{163}$ Honneth, 207, pág.71.

${ }^{164}$ Honneth, 2007, pág. 73.
} 
Para Hegel, a "solidão", "vacuidade", ou "abatimento" configuram situações e fenômenos do mundo social que expressam as patologias, ou efeitos negativos que afetam a auto-relação dos sujeitos. Honneth pensa essas patologias em conjunto como um "sofrimento de indeterminação" (Leiden na Unbestimmtheit), o que segundo ele constitui um diagnóstico de época. Segundo ele, Hegel elabora sua teoria da justiça vinculado a um diagnóstico de época que diz respeito a nosso tempo, baseado nas relações éticas de liberdade comunicativa. Isso configura para ele a necessidade desta teoria e sua utilidade para o contexto atual da discussão política sobre a justiça e as patologias do social.

\subsection{Patologias do Social e a Função "Terapêutica" da Eticidade}

Para Honneth, a concepção de justiça da Filosofia do Direito baseada no modelo de "amizade", no "ser-consigo-mesmo-no-outro", revela o fato de que as relações comunicativas, entendidas como "bens básicos", são produtos de "práticas" comuns, assim a "distribuição" desses bens, não pode ser pensada apenas na preparação das condições para tal (Rawls) ${ }^{165}$. A proposta de interpretação da tripartição da Filosofia do Direito está preocupada com a preservação das práticas contidas nas diferentes esferas comunicativas e, consequentemente, também com à auto-realização individual em todas as suas formas. Ou seja, Honneth está preocupado com as precondições das estruturas comunicativas da esfera ética. Para ele somente quando os sujeitos dispõem dos meios para se compreenderem como pessoas de direito, e subsequentemente, também como sujeitos morais, eles têm a possibilidade de atuar sem coação no quadro institucional da eticiadade, da esfera ética comunicativa. Essa autocompreensão enquanto pessoa do direito e enquanto sujeito moral decorre, no entanto, daqueles modelos insuficientes, mas imprescindíveis à liberdade. Estes sinalizam para um "sofrimento de indeterminação" quando autonomizados ou absolutizados.

Para Honneth, a filosofia prática de Hegel constitui uma crítica motivada pelo diagnóstico de época acerca dos modelos restritos de liberdade enquanto figuras da

\footnotetext{
165 Enquanto Rawls pretende resolver o problema de justiça a parte das condições das distribuições dos bem básicos, Honneth vislumbra essa possibilidade através da garantia das condições comunicativas éticas. Somente sob tais condições o sujeito pode se reconhecer como pessoa do direito e moral. Nesse sentido os modelos insuficientes são imprescindíveis. Constituem índice das patologias sociais que se impõe a realização da liberdade.
} 
consciência. ${ }^{166}$ Em Filosofia do direito, no entanto, delineia-se uma tentativa de superar as absolutizações e as confusões sobre como podem relacionar-se esses modelos de liberdade recém criados em sua época. Segundo Honneth, Hegel percebe em sua época a tendência social de tomar como totalidade um aspecto peculiar da liberdade. A compreensão da liberdade é entendida como relações centradas na liberdade jurídica ou moral e não no âmbito de todas suas esferas. Sua teoria da justiça tem, portanto, por tarefa demarcar a abrangência exata da liberdade moral e jurídica, isto é, do "direito abstrato" e da "moralidade", bem como diagnosticar os efeitos patológico no mundo da vida social que a absolutização de cada uma dessas esferas da liberdade pode ocasionar. Para Honneth, a conceito do espírito objetivo fornece a pressuposição necessária à articulação entre a teoria da justiça e diagnóstico de época. Este conceito, claro, desprovido de sua essência metafísica, contém a ideia de que a realidade social é composta de fundamentos racionais que, uma vez violados, causam prejuízos à autorelação das pessoas. Assim, a reatualização honnethiana busca delinear as positividades competentes ao direito abstrato e à moralidade, bem como também ao caráter da eticidade e, propriamente, do diagnóstico de época que Honneth julga extrair da teoria da justiça de Hegel.

Como Honneth faz notar no decurso da sua explicação sobre o direito abstrato, e também da moralidade, Hegel vincula a noção de liberdade própria dos direitos subjetivos e a noção própria da autonomia moral a diferentes concepções de ação. Esses modelos de ação crescem em complexidade e adequação social, e contribuem para a caracterização do direito abstrato e da moralidade visto que servem ao esclarecimento das orientações normativas dessas duas esferas.

No que diz respeito ao direito abstrato ou formal, no parágrafo $\S 41$ ao $\S 81$, Hegel trata da normatividade possível do direito natural e direito racional modernos enquanto elementos que contribuem para a realização da liberdade individual. Segundo Hegel o acesso aos objetos do desejo constituem pretensão legítima da liberdade da vontade, desde que elas sejam concedidas reciprocamente a todos outros sujeitos. Assim, portanto, segundo Honneth, o direito formal deve ser entendido como uma esfera de pretensões mutuamente autênticas, ou seja, uma intuição intersubjetiva. No direito formal os sujeitos participam somente com um mínimo da personalidade, pois "o que se exprime nos princípios do direito privado é somente aquele lado negativo da

\footnotetext{
${ }^{166}$ Honneth,2007.
} 
liberdade da vontade individual que consiste na negação de 'toda limitação e validade concretas' (§ 35)"167 e a liberdade individual pressupõe o reconhecimento da liberdade do outro, ou seja , a noção de liberdade do outro como meio para a satisfação do próprio interesse, a fim de aumentar as possibilidades da ação.

Para Honneth, os efeitos patológicos da absolutização desse tipo de liberdade devem ser explicados a luz da terceira seção dado a complexidade de sua explicação. Na parte dedicada a eticidade, a absolutização da liberdade jurídica configura em uma impossibilidade de participar na vida social. A fixação na liberdade jurídica, pressuposta pelo direito formal, sinaliza para o fato de que todo aquele "que articula todas as suas carências e intenções nas categorias do direito formal tornar-se-ia incapaz de participar na vida social e por isso sofreria de indeterminação" ${ }^{168}$. Isto porque a meta da ação que é motivada só pelo caráter jurídico da liberdade não caracteriza a ação como livre, ela se torna dessa forma insuficiente para a concepção de liberdade individual. $\mathrm{O}$ valor ético, no entanto, do direito abstrato em relação às precondições da auto-realização individual pode ser medido através do simples fato de que ele concebe as pessoas como portadoras de direitos, o que constitui a possibilidade de considerarem sua individualização como legítima no contexto da eticidade: "sua função [a do direito abstrato] consiste em manter no interior da eticidade uma consciência da individualização legítima, enquanto os limites se revelam logo que todas as relações sociais são reconstruídas em categorias de pretensões jurídicas" ${ }^{169}$.

Segundo Honneth, a ideia da autonomia moral é esclarecida por Hegel em referência a observações do seu diagnóstico de época e às deduções históricas. Nesse contexto a liberdade individual é pensada de forma oposta ao direito abstrato. A ação livre dessa vez constitui resultado da autodeterminação racional, não depende da liberdade do outro, o que se coloca como fundamental é a determinação racional ou reflexiva da ação. Conforme Hegel expõe no $§ 106$, a questão sobre a motivação ou propósito da vontade surge somente no âmbito da "moralidade", isto porque, é nesse contexto que a liberdade se revele como forma específica de autorrelação. Assim, portanto, a liberdade individual aparece somente quando o agir é articulado reflexivamente.

\footnotetext{
${ }^{167}$ Honneth, 2007, pág.87.

168 Honneth, 2007, pág.89.

169 Honneth,2007 pág.90.
} 
A autodeterminação racional constitui, dessa maneira, o parâmetro de medida para o direito de existência e valor da autonomia moral para a autorrealização individual. A compreensão das práticas sociais como o resultado de processos de avaliação reflexivos construídos com base em argumentos racionais aparece como algo imprescindível visto que na esfera da moralidade a ação reflexiva em relação à atuação do sujeito no contexto das atividades e interações constitui importância fundamental. Assim, em acordo com pressuposto do conceito de "espírito objetivo", a realidade social moderna aparece estruturada em fundamentos racionais.

Para delinear os problemas da absolutização da autonomia moral, Honneth retoma a objeção à filosofia prática de Kant. Para Honneth, o imperativo categórico Kantiano permanece cego em relação ao contexto e constitui orientação vazia em relação ao mundo circundante e prerrogativas normativas das práticas sociais do entorno: "A reflexão moral corre por assim dizer no vazio, porque não se pode perceber que a aplicabilidade do princípio de universalização se deve à confiança na validade

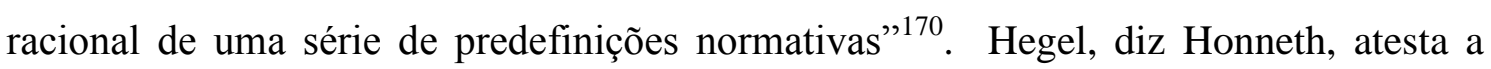
ineficácia da aplicação do imperativo num contexto em que se abstrai a institucionalização previa dos pontos de vistas morais: "enquanto abstrairmos o fato de que sempre nos movemos em um ambiente social no qual aspectos e pontos de vista morais já se encontram institucionalizados, a aplicação do imperativo categórico permanecerá ineficaz e vazia"171. A esse diagnóstico de uma cegueira do contexto, Hegel associa a compreensão daquelas prerrogativas normativas como sendo componentes racionais de uma práxis institucionalizada, isto é, como componentes do espírito objetivo. Para Honneth, embora com esse argumento Hegel escape a um relativismo moral, a questão sobre o sentido do conflito moral, lugar de aplicação do imperativo, permanece sem tematização. Para Honneth, o caráter normativo do seu argumento só é esclarecido no capítulo da "eticidade", visto que a normatividade racional se revela exatamente como eticidade. Enquanto a crítica a cegueira do imperativo categórico ao mundo circundante é uma crítica que advém propriamente do contexto da teoria moral, "a proposta de entender a realidade social como incorporação da razão apresenta no fundo um argumento epistemológico, ou melhor, ontológicosocial" ${ }^{172}$ que só fica melhor explicado na secção da "eticidade".

\footnotetext{
${ }^{170}$ Honneth,2003, pág. 85 .

${ }^{171}$ Honneth, 2007, pág.95.

${ }^{172}$ Honneth,2007, pág.95
} 
Para Hegel, segundo Honneth, a absolutização do aspecto moral da liberdade configura uma série de efeitos patológicos. Segundo seu diagnostico de tempo, a autonomatização do ponto de vista moral coincide com a perda da confiabilidade das normas sociais enquanto racionais e indubitáveis. A efetividade e o costume, ou "mundo existente da liberdade", perdem a confianças nas prerrogativas racionais que ele traz consigo. Para Hegel o individualismo romântico, no qual "o vazio interior e a pobreza da ação (...) é compensado por meio de uma recordação da voz da própria natureza"; a procura dos poderes tradicionais de uma fé e religião acrítica, a qual está em paralelo com uma fixação nos sentimentos e ânimos interiores que conduzem, por sua vez, a um processo de auto-reflexão infinita constituem traço marcante de sua época, ou seja, uma tendência a "perder-se num profundo apelo à própria consciência", centrar-se unicamente no princípio de universalização do próprio ponto de vista moral. Segundo Honneth, as patologias associadas a essa tendência conduzem, dessa forma, ao "sofrimento de indeterminação", ao aniquilamento dos preceitos práticos e à perda da ação.

Após tecer suas considerações sobre o valor ético e sobre as patologias do "direito abstrato" e da "moralidade", Hegel empreende um caracterização da passagem para a "eticidade" como a experiência por parte do sujeito individual de uma "libertação". Para Hegel, segundo Honneth, esta expressão carrega um duplo significado que sinaliza à desvinculação das duas perspectivas unilaterais de liberdade e aponta para a positividade do voltar-se para a liberdade real, a eticidade. A libertação diz respeito tanto aos impulsos naturais, da subjetividade indeterminada e "inefetiva" como diz no $\S 149$, quanto à liberdade em um sentido objetivo que implica a desvinculação de uma condição negativa e opressora, ou seja, um libertar-se "substancial". Essa formulação, portanto, configura-se na possibilidade de uma condição de liberdade efetiva. Assim a eticidade assume, diz Honneth, a função "terapêutica"; a filosofia do Direito, segundo ele, representa, no que diz respeito à liberdade semelhança com o procedimento terapêutico tal como a filosofia familiarizouse desde Wittgenstein.

Se tomarmos por base o esquema formal de uma compreensão terapêutica da filosofia, então o propósito do projeto de uma teoria alternativa da justiça não forma simplesmente o ponto de partida fático da Filosofia do Direito, mas principalmente a percepção de uma 
carência no mundo da vida ou de um "sofrimento" no próprio presente. ${ }^{173}$

Para Honneth, o "sofrimento", designado por Hegel através de expressões "quase psicológicas" que denotavam em conjunto estados de apatia, esvaziamento ou indeterminação, configura em conexão com a expressão de "imagem" que "nos mantinha presos" de Wittgenstein, uma "confusão conceitual" ocasionada pelas concepções unilaterais de liberdade institucionalizadas como resultado das atividades das práticas sociais cotidiana. A eticidade constitui, dessa forma, uma crítica terapêutica capaz de efetivar-se como estímulo construtivo de uma auto-reflexão libertadora. A teoria da justiça de Hegel, na visão Honnethiana, liga-se à perspectiva da emancipação entendida nos termos de uma libertação:

(...) a ideia de uma teoria da justiça, segundo a qual em sociedades modernas todos os sujeitos devem manter a chance de participar dessas esferas de interação, está ligada à emancipação precedente de um processo de formação erroneamente conduzido: sem a presentificação libertadora, uma vez que sofrem de "indeterminação" porque aceitaram despercebidamente concepções unilaterais de liberdade, os sujeitos não poderiam chegar àquele conceito de justiça ligado a uma teoria da intersubjetividade, o qual consiste na idéia de uma eticidade moderna ${ }^{174}$.

Para Honneth, portanto, as exigências da esfera da eticidade em Hegel devem poder levar a uma libertação duradoura das patologias ou sofrimentos sociais e denotar o caminho para a auto-realização individual de todos os indivíduos das sociedades modernas. Em tal esfera então se delineia uma teoria normativa da modernidade, crítica e preocupada com os pressupostos de uma vida social "justa" e boa.

\subsection{Doutrina da Eticidade como Teoria Normativa da Modernidade}

A última seção da obra hegeliana, a "eticidade", é analisada na perspectiva do papel desempenhado por essa esfera em relação às outras esferas, em relação ao diagnóstico e libertação do sofrimento de indeterminação e também em relação à

\footnotetext{
${ }^{173}$ Honneth,2007, pág.100.

${ }^{174}$ Honneth, 2007,pág. 103.
} 
conquista da liberdade real. Segundo Honneth, apesar das dificuldades em tratar do Estado e de uma relação política de formação democrática da vontade nesta parte da reflexão de Hegel, a teoria da eticidade pode ser interpretada como uma teoria normativa da modernidade. As esferas ético-sociais constituem, segundo ele, o núcleo fundamental e a possibilidade das instituições sociais. Para fundamentar essa formulação, Honneth precisa esclarecer as condições e exigências da eticidade para efetivação da auto-realização do indivíduo, bem como explicitar os pressupostos da eticidade ligadas ao reconhecimento.

Segundo Hegel, a esfera ética tem de cumprir fundamentalmente três condições para que possa possibilitar a auto-realização individual. A primeira exigência refere-se ás condições de interação necessárias à auto-realização. A realização da liberdade não pode prescindir dessas condições, as práticas de interação intersubjetiva que constituem o fundamento que permite a potencialização do escopo das possibilidades da auto-realização, ou seja, as formas de comunicação que revelam a liberdade individual como dependente das relações recíprocas entre os sujeitos. A segunda exigência diz respeito ao padrão da ação própria dessa esfera. Este além do seu caráter essencialmente intersubjetivo é caracterizado, segundo Honneth, somente através do conceito de "reconhecimento". Finalmente, a terceira exigência concebe formas específicas de reconhecimento recíproco como "atitudes" de reconhecimento. Isto representa, segundo Honneth, a tentativa hegeliniana de construir um modelo complexo de ação social capaz de tornar claros os processos de integração das sociedades modernas.

Depois de expor essas condições e exigências da eticidade à efetivação da auto-realização individual, Honneth precisa explicitar os pressupostos da eticidade ligados ao reconhecimento. Para ele, Hegel realiza essa tarefa desenvolvendo como fica explicito no $\S 148$, uma “doutrina ética dos deveres”. O dever é entendido em conexão com o reconhecimento, ou seja, diferentemente do "dever" de Kant, o qual representa para ele, segundo Honneth, um "princípio vazio da subjetividade moral". Em contrapartida o "dever" na "Filosofia do Direito" expressa relações necessárias, reconhecidas e respeitadas como obrigatórias e evidentes.

(...) um dever não representa para Hegel aquele ponto de vista isolado que Kant quis antepor à escolha entre alternativas de ação enquanto critério de decisão, senão o elemento interno, "necessário", de uma 
ação que pode ser a expressão do reconhecimento; e a elaboração de uma "doutrina ética do dever" significa correspondentemente fornecer um panorama sistemático sobre as formas de ação intersubjetiva que podem expressar reconhecimento graças à sua qualidade moral ${ }^{175}$.

Segundo Honneth, as estruturas ou relações éticas da vida social, no contexto de uma "doutrina da eticidade", só podem ser determinadas a partir dos padrões intersubjetivos baseados no reconhecimento recíproco que permitam a auto-realização dos membros da sociedade. Para Hegel as inclinações humanas não podem ser consideradas enquanto mero dado, como algo fixo e imutável, mas pensadas mediante a socialização de seus espaços de transformação e configuração, ou seja, dos processos de limitação e formação dos potenciais naturais. A limitação e formação das inclinações e carências estão relacionadas com os deveres e mandamentos, segundo Honneth, na forma de uma teoria epistemologica no qual os processos de formação são tomados como um processo de aprendizado gradual das esferas de interação éticas. Dessa forma a eticidade deve garantir práticas de interação que permitam a autorealização; práticas de reconhecimento recíproco e práticas de formação correspondente de conhecimento recíproco. Essas três condições mutuamente condicionadas constituem a base da doutrina da eticidade. "Sofrimento de Indeterminação" constitui dessa forma uma teoria da sociedade no qual os componentes da sociedade são explicados pelas condições da esfera de ação social que revelam os critérios normativos. Honneth caracteriza dessa forma o propósito de Hegel como uma reconstrução normativa.

\subsection{Crítica à "superinstitucionalização" da eticidade em Hegel.}

No entanto, para Honneth, a classificação hegeliana da eticidade em três âmbitos de ação, os âmbitos da "família", "sociedade civil" e "Estado", revela de maneira mais explicita os diversos problemas do pensamento político de Hegel e também os problemas de uma reatualização do seu pensamento. A combinação da auto-realização, reconhecimento e formação da maneira exigida, necessita, diz Honneth, de uma interpretação dos complexos sociais e institucionais da "família" da "sociedade civil" e

\footnotetext{
${ }^{175}$ Honneth,2007, pág. 112.
} 
do "Estado" de maneira independente da "Lógica" e das operações do espírito e também o tratamento desses âmbitos da eticidade de uma forma mais "abstrata", visto que Hegel tinha em vista primordialmente as instituições ancoradas no direito.

A relação existente entre a "família", a "sociedade civil" e o "Estado" tal como caracterizada por Hegel, segundo Honneth, configura uma relação hierárquica que segue uma linha ascendente, passível de ser explicada sem a necessidade de referência aos pressupostos lógicos do sistema. A família ou "eticidade na forma natural", como diz Hegel no $§ 158$, constitui o ponto de partida dessa ordem hierárquica, ou seja, a base elementar de toda eticidade. Esse momento da eticidade representa o lugar de satisfação intersubjetivas dos impulsos individuais (como na relação sexual entre parceiros) e lugar de organização e formação dos potenciais das carências da criança, através do reconhecimento afetivo dos pais: "sem o reconhecimento intersubjetivo ao qual chegam as pulsões no espaço interior da família, a formação de uma 'segunda natureza', de um fundo socialmente partilhado em costumes e comportamentos, não seria possível"176. Esse momento de eticidade constitui o lugar da realização do amor concebido como forma de reconhecimento recíproco que permite o estabelecimento de laços de confiança e companheirismo necessários à participação dos costumes e comportamentos socialmente partilhados. Dessa maneira, a espaço familiar, constitui espaço social de autorealização individual, permite o indivíduo a libertação da desoneração natural e da afirmação e autolimitação das inclinações e carências sensíveis.

Segundo Honneth a passagem da "família" para a "sociedade civil" é marcada por argumentos que remontam a "lógica" do sistema hegeliano, o que o leva a embasar seu entendimento dessa esfera no que diz respeito ao seu papel na eticidade nos escritos de Hegel do período de Jena. Em conformidade com o exposto em Luta por Reconhecimento Honneth concebe a esfera da "sociedade civil" como o âmbito que concentra as atividades de troca do mercado capitalista mantidas pela lógica da concorrência. A 'sociedade civil', entendida então como esfera da circulação mediada pelo mercado entre os proprietários, representa para Hegel o meio tanto de uma destruição da eticidade imediata como também da possibilitação de um isolamento extremo" ${ }^{177}$. Essa esfera configura, portanto, por um lado, a destruição da eticidade imediata visto que nas relações do mercado capitalista ocorre conforme a racionalidade com respeito a fins, a busca da satisfação dos interesses egoísta, indiferente em relação

\footnotetext{
${ }^{176}$ Honneth, 2007, pág.118.

${ }^{177}$ Honneth, 2007, pág.128.
} 
às necessidades do outro parceiro e; por outro lado, também constitui o lugar da realização de uma universalidade indireta que permite certa reflexibilidade a respeito das relações familiares; o reconhecimento aparece como pressuposto normativo dos contratos e ações particulares, o que torna a autorealização correspondente atrelada ao reconhecimento do outro enquanto parceiro do contrato e das obrigações derivadas do mesmo. Dessa forma, o processo de transformação das carências naturais em interesses próprios do âmbito do mercado capitalista, ou seja, que expressa à idéia de "formação", significa também, como diz Hegel no $\S 187$, uma "libertação" da "mera subjetividade do comportamento" e da "imediatez dos desejos, em direção aos interesses e competências da racionalidade com respeito a fins. A "sociedade civil" constitui dessa forma uma etapa superior em relação à família. Enquanto nesta, o sujeito é ainda um membro de uma comunidade da qual não escolheu fazer parte, nas relações mediadas pelo mercado os sujeitos que as compõem já se compreendem como pessoas de direito individualizadas.

Por sua vez, o Estado, segundo Honneth, tem que representar um nível maior na individualização dos sujeitos. Para ele o texto de Hegel aponta para compreensão segundo o qual os sujeitos no âmbito dessa esfera são concebidos como portadores de uma individualidade superior. Isto porque, como Hegel indica no $§ 255$, no "Estado", os sujeitos seriam capazes de se compreenderem como seres dotados de razão e de exercerem "uma atividade universal". Ao estado competiria a garantia das atividades em funções de interesses públicos e éticos em um sentido universal. O sujeito que colabora na reprodução da coletividade através de seus talentos, disposições e habilidades formadas racionalmente levariam dessa forma "uma vida universal", ou seja, atuariam como um membro da sociedade.

A hierarquia normativa encontrada na sequência dessas diferentes esferas da eticidade é composta, segundo Honneth, pela formação racional e descentrada da subjetividade. Estas teriam por fim revelar as condições de realização da liberdade individual nas esferas das sociedades modernas, e também decifrar as relações existentes entre as formas de subjetividade, de reconhecimento e autorrealização. Para Honneth, Hegel ao caracterizar os âmbitos da esfera da eticidade parece supor uma sequência de carência, interesse e honra correspondentes à "família", "sociedade civil” e "Estado", respectivamente. O aumento da personalidade individual, ou da formação racional da individualidade acompanha gradualmente o desenlace dessa sequência no 
horizonte da "sensação" (família), da racionalidade com respeito a fins (sociedade civil) e da razão (Estado), sendo que também a cada nível corresponderiam jogos de linguagem distintos. Segundo Honneth, há em Hegel um processo de descentramento progressivo limitado pelo interesse comum da comunidade concreta:

a tese sistemática de que as chances de individualização de um sujeito aumentam com o grau de sua capacidade de universalização das próprias orientações o que levaria a enxergar que a sequência de carência, interesse e honra significa um esquema de nivelação no qual o processo de individualização é equiparado com um processo de descentramento progressivo ${ }^{178}$.

No entanto, segundo Honneth, essa divisão da esfera da eticidade acarreta uma série de dificuldades. No âmbito da família Hegel além de seguir os traços marcadamente patriarcalistas, atribuído exclusivamente a mulher o papel da educação dos filhos e trabalho doméstico e ao homem os papéis efetivos como os do Estado e da ciência, exclui a "amizade", que havia sido tão importante na sua caracterização da vontade livre na introdução, da caracterização das potencialidades éticas da primeira esfera da eticidade. Esta ausência, diz Honneth, leva a Hegel restringir esta esfera de ação ao espaço da pequena família burguesa e impede que a teoria da justiça um alcance de maior amplitude, visto que sua análise fica restrita à apenas um tipo de relacionamento. Esse encaminhamento, de acordo com Honneth, levara Hegel a concluir que:

(...) tais relações de interação da sociedade moderna só podem ser compreendidas como elemento social da eticidade que incide sobre as prerrogativas de organização do Estado e são, desse modo, institucionalizáveis de acordo com o direito positivo; pois sem tal possibilidade de um acesso estatal, as esferas correspondentes não teriam sequer base de durabilidade, confiabilidade e instaurabilidade necessárias para se falar de uma condição de liberdade para nós disponível $^{179}$.

\footnotetext{
${ }^{178}$ Honneth, 2007, pág. 123.

${ }^{179}$ Honneth, 2007, pág. 131.
} 
O Estado assumiria além da terceira esfera da eticidade o papel de organizador das outras esferas éticas de interação, somente as relações legalmente institucionalizadas constituiriam efeito para a liberdade. A "família", por meio do contrato matrimonial, seria preterida em relação às relações contingentes como Hegel diz no adendo ao $\S 161$, ou seja, em relação à amizade e as relações afetivas não institucionalizadas.

Para Honneth a representação das esferas de eticidade "pensadas como relações sociais de interação nas quais todo sujeito deve poder participar igualmente por razões da liberdade", como bens públicos na medida em que permanecem amplamente controladas pelo estabelecimento do direito através do Estado resulta na diminuição do caráter ético das condições de liberdade. Para ele a noção de "instituição" poderia ser compreendida de uma forma diferenciada:

(...) práticas de ação que são dispensadas da rápida mudança ao assumirem a forma de rotinas e hábitos partilhados intersubjetivamente, ou seja, de "costumes", podem ser, de um certo modo, entendidas como "instituições"; ainda que falte nelas o ancoramento em sanções jurídicas do Estado, possuem, no entanto, "firmeza" e estabilidade suficientes para não estarem submetidas permanentemente aos "caprichos" de nossos sentimentos ${ }^{180}$.

Além disso, ele também destaca que Hegel não deixa um espaço, no complexo das esferas do reconhecimento, para a ação em sua forma de institucionalização social e também não distingue os pressupostos jurídicos necessários a existência de um esfera ética da tese de que uma instituição necessita de um contrato sancionado pelo Estado para existir. O preenchimento dessas lacunas, diz Honneth, poderiam ter conduzido Hegel a compreender as relações de comunicação produzidas no processo de modernização não como reduzidas ao resultado do processo de institucionalização, ou seja, à "instituição", isto , porque, elas se caracterizam como hábitos que estão sempre em transformação e adaptação, visto que partem dos elementos motivacionais da ação sempre contextualizados. Honneth defende uma idéia de reconstrução que representa uma crítica a Hegel e também ao modelo reconstrutivo 
de Habermas no qual aquilo que "antes foi chamado de 'reconstrução normativa' não significaria então, sob essas condições levemente revisadas, reconstruir realidades juridicamente institucionalizadas", mas sim "reconstruir as esferas sociais de valor da modernidade que se caracterizam pela ideia de uma combinação determinada de reconhecimento recíproco e auto-realização individual" 181 .

Em relação ao capítulo relativo à "sociedade civil", Honneth critica a concepção hegeliana de instituições muito diferentes entre si em reação às normas e às práticas de ação, tais como as que ele concebe sob o termo de "corporações". Para ele isto impossibilitaria a caracterização dessa esfera de eticidade com um único padrão de interação, e implicaria numa imensa dificuldade de atualização, visto que diminuiria a possibilidade de abstração dos termos. Segundo Honneth ao conceber sob "corporação" um subsistema ético, Hegel pretendera compensar as tendências de desagregação social do sistema de mercado capitalista. Este subsistema seria regido por orientações éticas voltadas às atividades do trabalho exercidas num sentido público, ou universal, isto é, para o bem de toda a sociedade. Essa tentativa de etização dos empreendimentos industriais, diz Honneth, além de revelar certa ingenuidade, inclui outra forma de reconhecimento e padrão de ação na esfera da "sociedade civil" causando confusões que Hegel não pode perceber o que revela novamente o problema fundamental de execução da doutrina da eticidade:

(...) ainda que tudo nela esteja disposto de tal maneira que se constitua nas três esferas apenas um padrão de interação capaz de garantir a liberdade, essa intenção formal não pode ser realizada porque seu ponto de vista está voltado muito fortemente para as formas concretas de organização ${ }^{182}$.

Assim, portanto, no que diz respeito ao capítulo da "eticidade" da Filosofia do Direito, de acordo com Honneth, a intenção de examinar as estruturas normativas das sociedades modernas para tentar averiguar as condições historicamente constituídas da liberdade individual é confundida com a pretensão de analisar as instituições que legitimam as formas concretas de organização, e principalmente aquelas constituídas juridicamente. Esta tendência a uma "superistitucionalização" impedira Hegel de enxergar a "sociedade civil" a partir daquela universalidade indireta e também o

\footnotetext{
${ }^{181}$ Honneth, 2007, 136.

182 Honneth, 2007, 141.
} 
entendimento da "corporação" como uma espécie de "liberdade pública" pensada na esfera do "Estado", uma divisão de trabalho democrática e publicamente mediada. Para Honneth, a autorrealização dos sujeitos na "via universal", não considera a ideia de uma liberdade pública. Embora o "universal" seja caracterizado muitas vezes como o significado ético do Estado, não representa um universal "substancial", onde o papel do sujeito como "cidadão do Estado", ou "súdito a serviço", parece preponderar em detrimento do papel do cidadão capaz de atuar numa esfera publica política e na formação democrática da vontade. Hegel ainda variaria de uma posição republicana de crítica ao Estado de necessidade e do entendimento, ao esboço de um patriotismo constitucional, sempre manifestando um "liberalismo autoritário" no qual não haveria

(...) a previsão de um lugar único no qual os "cidadãos do Estado" pudessem reunir-se para deliberar em conjunto sobre como deveriam ser qualificados os fins considerados "universais"; não se encontra na doutrina do Estado de Hegel o menor vestígio de idéia de uma esfera pública política, da concepção de uma formação democrática da vontade $^{183}$.

Apesar de conferir aos indivíduos os direitos fundamentais tradicionais, segundo a argumentação honnethiano a participação na formação política da vontade ficou limitada nos moldes com que Hegel a caracterizou. Mesmo estabelecida à legitimidade do Estado pelo consentimento livre de cada cidadão, os membros da sociedade não gozam de procedimentos de deliberação pública e de formação de opinião.

Em Sofrimento de Indeterminação, Honneth continua a "elucidar categorialmente a realidade social". Desta vez, ele ocupa-se com os modelos de liberdade comunicativa próprios das esferas sociais normativas da modernidade e com as esferas sociais do reconhecimento. Honneth volta a enfatizar o padrão normativo das formas do reconhecimento recíproco e das formas de auto-realização individual, mas desta vez resguardando certa estrutura de direitos, liberdades e deveres por meio de uma noção de vida boa.

Pela atualização do "espírito objetivo" e da "doutrina da eticidade", Honneth compõe uma teoria normativa da modernidade, porque para ele a doutrina da eticidade contém em si as esferas ético-sociais cujo núcleo constitui o fundamento e

\footnotetext{
${ }^{183}$ Honneth, 2007, pág.144.
} 
possibilidade das instituições sociais. A atualização da "doutrina da eticidade" hegeliana preconiza uma reconstrução das relações modernas da vida, em um sentido normativo, quer dizer, ancorado nos padrões de interação necessários à efetivação bem sucedida da auto-realização individual. Nesse sentido, a importância do conceito de "espírito objetivo", despido de sua essência metafísica, está no fato de ele conter a ideia de que a realidade social é constituída de fundamentos racionais que, uma vez violados, causam prejuízos à auto-realização dos indivíduos. Esses fundamentos racionais são as próprias esferas e práticas sociais estruturadas pelo reconhecimento. Os direitos universais estabelecidos pertencem apenas mediatamente à esfera do indivíduo e primeiramente às relações e estruturas sociais, às formas de "existências" sociais necessárias para a realização da "vontade livre". Essa constatação abre a perspectiva de caracterização das esferas sociais como núcleo e fundamento das formalizações e institucionalizações societárias no pensamento de Honneth.

A partir dessa determinação do "social", é possível caracterizar teoricamente a modernidade através de uma "reconstrução das esferas sociais da modernidade" e não simplesmente por intermédio de uma reconstrução das instituições da modernidade. Assim, a teoria normativa da modernidade precisa mobilizar as estruturas e relações éticas da vida social, dito de outro modo, ela é capaz de lidar com o padrão de práticas intersubjetivas que permitem aos membros da sociedade a possibilidade da autorealização, na medida em que se relacionam uns com os outros, enquanto relacionamento moral baseado no reconhecimento recíproco. O caráter dessa teoria normativa da modernidade, como reconstrução das esferas sociais modernas, deixa entrever a crítica anti-institucionalista que Honneth faz à teoria do Estado contida na Filosofia do Direito de Hegel. Tal crítica tem como alvo aquilo que Honneth chama de “superistitucionalização" das esferas da eticidade (família, sociedade civil e Estado)

Finalmente, a preocupação com relação à eticidade e à atualização do espírito objetivo- e igualmente com a crítica à superinsitucionalização das esferas ético-sociais, em Hegel- dá o tom da abordagem adotada por Honneth em Sofrimento de Indeterminação. Ela mantém o núcleo da sua teoria da justiça nas esferas sociais e na conceitualização do social, enquanto fonte materialista e conflituosa tanto das ações e movimentos sociais quanto dos processos de formalização e institucionalização das normas societárias. 
O pensamento social de Honneth procura se contrapor à duplicidade das esferas racionais como "complexos institucionais", tal como propõe a teoria da ação comunicativa de Habermas. Como decorre de sua crítica à doutrina da eticidade, tanto o domínio da racionalidade sistêmica quanto o da comunicativa têm suas raízes nas esferas sociais de geração das ações e esse núcleo social não pode ser abstraído ou tomado secundariamente. Embora, as relações "enrijecidas" institucionalmente premeiem toda ordem social, o núcleo motivador e central dos desenvolvimentos e mudanças históricos encontram-se nas relações comunicativas entre grupos integrados social e culturalmente.

Honneth desloca para o centro da sua teoria as relações morais bem como as práticas e esferas ético-sociais. Com isso, ele procura não abstrair os fenômenos patológicos, "exportando-os" para complexos de razão. Assim ele não subestima o papel determinante dessas patologias na experiência vivida dos indivíduos. Da mesma forma, ele não negligencia o potencial de organização emancipatória contido nos movimentos e reivindicações por reconhecimento e dignidade. $\mathrm{O}$ conceito formal de eticidade e os modelos de liberdade comunicativa da teoria normativa da modernidade servem como critérios normativos para a avaliação dessas lutas sociais em referência ao seu caráter emancipatório ou reacionário.

A teoria do reconhecimento proposta por Honneth revela a preocupação em considerar a importância das esferas sociais em relação ao seu papel fundador de movimentos e reivindicações que visam a formas de emancipação e à libertação do sofrimento e do desrespeito nas sociedades capitalistas modernas. Estes fenômenos patológicos muitas vezes são encobertos por configurações demasiadamente institucionalistas destas sociedades, cujo funcionamento em muitos casos pode até mesmo "barrar" a possibilidade de articulação e reivindicação coletivas por reconhecimento, dignidade e justiça. $O$ que a teoria normativa honnethiana positivamente pode enfatizar e indicar é a necessidade de maior "abertura" dos âmbitos institucionais para com movimentos coletivos que lidam e interpretam, em ampla medida, práticas sociais e institucionais como sendo desrespeitosas ao seu modo de vida. A preocupação com a formação da liberdade, com os processos de aprendizagem sociais e com o diagnóstico de patologias que afetam o mundo da vida seguramente fornece um contraponto cuja positividade é apontar para uma maior participação e protagonização dos indivíduos e sujeitos sociais nos processos de construção e 
configuração da política democrática, e também do asseguramento e compartilhamento de seus modos de vida identitários e coletivos. 


\section{CONSIDERAÇÕES FINAIS}

A presente dissertação constituiu um esforço em elucidar o conceito e o papel do "social" no modelo crítico de uma Teoria do Reconhecimento proposto pelo filósofo alemão Axel Honneth. A inserção de Honneth no debate acerca da herança do legado da Teoria Crítica ocorre com o livro "Crítica do Poder", no qual imputa a tradição crítica um "déficit sociológico". É possível depreender das análises realizadas por Honneth nesta obra que o problema central enfrentado pela Teoria Crítica é o desenvolvimento de um conceito de "social" que "integre todo espectro da ação cultural cotidiana"184, no qual cada um de nós é tão completamente incorporado. Para Honneth, os modelos críticos de Horkheimer, Adorno, passando por Foucault até chegar em Habermas, apresentariam uma incapacidade de acessar teoricamente os domínios da ação social, eles não apresentariam uma capacidade efetiva de analisar as dinâmicas sociais de conflito. Para Honneth, estes autores não observam, na própria ação dos sujeitos, potenciais normativos de superação das situações de dominação diagnosticadas.

Segundo Honneth, a obra daqueles autores é marcada pela preponderância da análise sistêmico-institucional, o que impedira, de diferentes maneiras, que eles pudessem observar formas de resistência e reorganização levadas a cabo por grupos de atores no nível da própria integração social. As relações de entendimento, de acordo com Honneth, estabelecidas por meio de consensos comunicativos, no sentido inicialmente observado por Habermas, perdem espaço nos modelos daqueles autores e são subjugadas por explicações que privilegiam a extensão das estruturas sistêmicas de dominação, como é o caso dos complexos produtivos, das instituições sociais ou das esferas de racionalização da vida social. Dessa maneira o primeiro ponto a ser analisado foi justamente a crítica de Honneth à ausência de dimensões de análise sociológica na Teoria Crítica de seus antecessores.

Horkheimer, de acordo com Honneth, se mantém preso a uma noção de progresso histórico que sobrevaloriza a conquista material da natureza em detrimento das relações morais formadas pelos sujeitos, assim permanece vítima de uma filosofia da História que se torna totalitária em seu modelo: apenas a evolução das formas produtivas poderia resultar num processo emancipatório, mas esta evolução já ocorre sob o capitalismo e se reverte em destruição da razão e, assim, da possibilidade de

\footnotetext{
${ }^{184}$ Honneth, 1991,p.99.
} 
emancipação humana. Essa aporia encontra seu ponto mais elevado com a Dialética do Esclarecimento, que representa segundo Honneth a incapacidade da primeira geração crítica em responder suas próprias questões sobre a capacidade emancipatória das sociedades modernas. Para Honneth o objetivo de autores como Adorno e Horkheimer, quando tratavam das esferas cultural e psíquica, era determinar em que medida a formação de estruturas de dominação capitalista de um novo tipo- o capitalismo de Estado- bloqueava as possibilidades emancipatórias ocupando o lugar de realização das promessas iluministas. Enquanto Horkheimer preocupa-se com o fato de que as lutas sociais de sua época não representariam uma fonte expressiva de contestação de um sistema que se torna cada vez mais totalitário, Honneth pretende ver nestas lutas a dimensão estrutural da ação social crítica, compreendendo a ação social não como uma forma de resposta às instituições sociais, mas como uma forma de atividade passível de ocupar o espaço de movimento emancipatório. É essa diferença de concepção da integração social que o conduz também à avaliação das obras de Foucault e Habermas.

Embora Honneth identifique na teoria de poder desenvolvida por Foucault uma possibilidade alternativa de integração social, por meio de disputas incessantes pela obtenção de recursos de dominação no seio de uma sociedade, questiona neste modelo a ausência de processos de formação de consensos e normas de ação, o que segundo Honneth, leva o próprio Foucault a abandoná-lo em favor de uma noção de dominação apoiada no poder das instituições sobre os sujeitos. Em contraponto a essa carência da teoria foucaultiana do Poder, Honneth aceita a noção habermasiana de que a esfera da comunicação é um componente necessário da evolução social. No entanto, o modelo de uma teoria da ação comunicativa em que a interação por meio da comunicação livre de coerção é oposta por um processo de racionalização das esferas de sociabilidade que se expande sobre as esferas morais de comunicação, ainda não é satisfatório para Honneth. Ao contrário de Habermas que se ocupa em encontrar uma alternativa à filosofia da História que levara Horkheimer e Adorno a aporia da dialética do esclarecimento, Honneth pretende retomar a importância da ação comunicativa como atividade crítica.

Esse conceito é de fundamental importância para o desenvolvimento da sua teoria do reconhecimento. É exatamente com ele que Honneth pretende retomar a tarefa originalmente proposta por Horkheimer. Para Honneth o espaço de ação social é caracterizado principalmente por esta atividade crítica fundada no conceito de ação comunicativa. No entanto, este conceito sofre uma alteração importante, não se trata 
mais de explicar a latência dos conflitos sociais em sociedades modernas e sim de demonstrar como a dinâmica de conflitos sociais desenvolve-se de uma maneira que a Teoria Crítica não poderia observar com sua primeira formulação. Assim, portanto, seu próximo passo é formular uma teoria que superasse os déficits que ele apontara na tradição crítica por meio de uma caracterização crítica do "social" de modo a desvendar os mecanismos da interação social. Em "Luta por Reconhecimento", Honneth retoma o modelo de teoria do reconhecimento desenvolvida por Hegel em Jena, e apresenta a ideia de que a Teoria Crítica deveria se orientar por uma formulação capaz de perceber as motivações da atividade crítica. Honneth está preocupado em determinar como ocorre a dinâmica das lutas sociais que podem se revestir de caráter emancipatório. Assim, em sua visão, "o social” deveria ser analisado a partir dos sentimentos e motivações que levam os sujeitos a procurarem novos consensos e normas de sociabilidade. A emancipação, dessa forma, é tratada como uma questão de autorealização e permite, tendo como perspectiva as motivações dos conflitos, a concepção de uma teoria em que os conflitos sociais aparecem como elemento da interação comunicativa.

Dado essa demarcação da estrutura de sua teoria, pode-se notar que na análise crítica de seus antecessores na tradição crítica incluindo Foucault, Honneth não apresenta um conceito específico do "social". O mais próximo que ele chega de uma definição aparece na conclusão do livro: o social é "uma relação comunicativa institucionalmente mediada entre grupos culturalmente integrados que, uma vez que o exercício do poder é distribuído de forma assimétrica, ocorre por meio da luta social"185, e que é constituído por " construções frágeis que mantêm sua existência dependente no consenso moral de todos os participantes" 186 . O "social" é tomado ao mesmo tempo como o lugar de um poder assimétrico, luta social e como consenso moral. É exatamente a ambiguidade desse conceito que define o "social" como um problema crucial a Teoria Crítica.

Embora Honneth não desenvolva neste livro o conceito de social, ele aponta, no posfácio que escreveu para o livro em 1988, que seu modelo de análise do conflito social pode ser desenvolvido a partir das ideias de Habermas desde que a logica comunicativa consensual, que orientaria a integração no mundo da vida no modelo habermasiano, fosse substituída por uma teoria da integração em que os contatos entre

\footnotetext{
185 Honneth, 1991, p.303.

${ }^{186}$ Honneth, 1991, p.302.
} 
sujeitos são concebidos como uma luta pelo reconhecimento de suas identidades, de modo que o conflito social remete a demandas morais dos sujeitos.

Somente em "Luta por Reconhecimento" que Hegel desenvolve sua teoria da comunicação e dessa forma esclarece seu conceito de "social", no qual a ação comunicativa representaria um indicador para os mecanismos pelos os quais a organização de todos os domínios sociais da ação é regulada. Assim a crítica a Teoria Crítica serve de entrada à construção de um modelo teórico do reconhecimento que se sustente nos avanços proposto por Habermas à ideia original de Hokheimer. Honneth não interpreta a interação comunicativa a partir de uma logica universal abstrata, mas como um elemento efetivo da vida social a partir de uma teoria da intersubjetividade.

O conceito de luta por reconhecimento constitui a chave para empreender sua reconstrução do "social". É a partir deste conceito que Honneth pretende sustentar, por um lado, uma crítica do "déficit sociológico" e, por outro lado, tratar a integração social como uma questão normativa. Para Honneth a realidade social é estruturalmente constituída por esferas sociais do reconhecimento a partir das quais ele pode extrair os critérios normativos para sua Teoria do Reconhecimento e da justiça. Esta nova abordagem consiste em "elucidar categorialmente a realidade social", situando o conflito social e os sentimentos de desrespeito e injustiça no centro da Teoria Crítica. As patologias sociais são interpretadas como fenômenos negativos advindos do interior mesmo das práticas e estruturas sociais que são concebidas de modo a compor o núcleo gerativo das ações e da possibilidade dos processos de formalização e institucionalização.

A partir do conceito de reconhecimento, Honneth pode conceber uma teoria da formação da personalidade que o permite tratar a integração social a partir de um viés normativo. A formação bem sucedida da personalidade constitui o fundamento normativo do reconhecimento que os indivíduos esperam receber, isto porque esta formação ocorre por meio de conflitos intersubjetivos que, quando socializados, passam a ser conflitos entre grupos pela obtenção de reconhecimento de suas especificidades.

Honneth está preocupado com a integridade da personalidade individual que se forma em meio a processos sociais e com sua contrapartida negativa, o desrespeito. Estas duas relações, reconhecimento e desrespeito, são tomadas por Honneth como sentimentos que decorrem da existência de auto relações que, por sua vez, se desenvolvem através de relações sociais, que são responsáveis tanto pela formação de 
expectativas normativas e sentimentos individuais quanto de sentimentos de desrespeito e opressão. No modelo de Honneth, baseado nos estudos de Hegel e George Herbert Mead, estas auto relações são a autoconfiança, o auto-respeito e a auto-estima, que representam respetivamente, três esferas de reconhecimento (ou de desrespeito social, em suas versões negativas): o amor, o direito e a solidariedade. Enquanto na primeira esfera de relações interpessoais, a do amor e das relações pessoais, o reconhecimento se liga ao desenvolvimento psíquico da personalidade, nas duas outras esferas, do direito e da solidariedade, a ideia de reconhecimento liga-se à participação na vida cultural de uma comunidade, seja por meio das reivindicações de grupos particulares junto às esferas jurídicas, seja quanto às suas reivindicações que remetem à esfera da sociedade civil. Honneth parte da formulação materialista das formas elementares do convívio e experiência intersubjetivas, passa pelas estruturas das relações sociais, chega à elaboração das formas de desenvolvimento e evolução sociais baseadas no reconhecimento e finalmente fornece um padrão normativo de avaliação das lutas sociais, por meio de um conceito formal de eticidade. Com isso, ele amplia a conceituação do social e suas esferas, ao derivar das formas elementares da interação o âmbito da estrutura e gramatica moral dos conflitos sociais.

Embora a teoria retire sua dimensão normativa das demandas dos sujeitos pelo seu reconhecimento, esta também abarca as esferas de produção cultural e institucionalização da participação social. Uma vez que a formação da personalidade completa passa pelo reconhecimento do mundo social, as demandas morais por reconhecimento tem por efeito a ampliação das relações de reconhecimento. A teoria do reconhecimento prevê uma passagem de uma formação intersubjetiva para lutas pelo reconhecimento coletivo de diferentes valores éticos. Honneth procura com seu modelo atualizar a ideia hegeliana de um sistema de eticidade ao mesmo tempo em que procura abarcar, com seu modelo teórico, as esferas individual e social do desenvolvimento pessoal. O sentido crítico desta teoria seria então o de observar na relação entre as expectativas normativas dos indivíduos e as estruturas de integração a possibilidade de superação de situações de desrespeito e a construção de um sistema de eticidade.

A teoria do reconhecimento de Honneth, então, procura transformar o modelo habermasiano da teoria da comunicação consensual em uma teoria intersubjetiva do conflito pela integração e pelo reconhecimento de demandas morais de grupos de indivíduos, tanto por meio de demandas positivas quanto por meio de conflitos pela 
superação de situações de reconhecimento denegado. Nesta proposição nota-se que a dimensão psíquica do conceito de reconhecimento possui uma relação formal com os motivos de ação. Esta relação é sintetizada na ideia de que as expectativas normativas do sujeito quanto à sua identidade são os motivos para a luta por reconhecimento quando desrespeitadas. Mais importante, contudo, é o fato de que estas expectativas dizem respeito à participação dos sujeitos na vida comunitária, de modo que a dimensão psíquica normativa possui um reflexo sobre as organizações sociais existentes ou, pelo menos, sobre as demandas das lutas sociais por esta organizada. Esta é a solução que Honneth parece ter encontrado, em um primeiro momento, para a superação do "déficit sociológico" da teoria crítica. Assim a teoria do reconhecimento proposta em sua teoria busca critérios ético-normativos internamento ao mundo social com vista a atacar os problemas normativos de ordenação e conflito entre atores envolvidos nessas lutas, os processos de formação de demandas por reconhecimento funcionam como impulsos para dinâmica histórica de ampliação das relações de reconhecimento. Honneth elabora uma teoria da relação entre formação intersubjetiva e horizonte normativo, entre teoria normativa e sociologia.

Honneth propõe um tipo de análise do conflito em que tanto a dimensão formativa individual quanto a dimensão interativa da identidade se relacionam ao estabelecimento de padrões normativos de socialização que, por sua vez, remetem à relação entre estes processos. Há na perspectiva honnetiana uma espécie de dialética positiva entre reconhecimento e a diferenciação de identidades que leva àquela ampliação das relações de reconhecimento. $\mathrm{O}$ especificamente sociológico da teoria do reconhecimento decorre do que Honneth chama de um processo de logica moral de ampliação das relações de reconhecimento. A expansão das instituições reguladoras da sociedade resultaria segundo Honneth dos conflitos sociais pelo reconhecimento da identidade ou pelo processo de integração social formada intersubjetivamente. Ou seja, a interação social e a luta por reconhecimento estariam intimamente ligadas e sua articulação se daria em torno de concepções de bem estar individual e coletivo reconhecidas por outros membros da sociedade nas esferas jurídica e da solidariedade. Assim o especificamente sociológico da teoria do reconhecimento pode ser associado ao estabelecimento de um patrão normativo de socialização no qual a relação entre interação e ampliação dos padrões de reconhecimento fosse garantida. 
De acordo com a proposta de Honneth, portanto, uma integração social justa é aquela que respeita a diferença e a abriga como positiva ao mesmo tempo em que vê as lutas sociais como elementos fundamentais da ampliação desta aceitação. O modelo que Honneth defende é o de uma reatualização da noção hegeliana de eticidade.

Com a reformulação do conceito de eticidade ao final de Luta por Reconhecimento, Honneth pretende não só dar uma justificativa prática para as lutas por reconhecimento, mas também demostrar como a ideia de uma rede de reconhecimento sustentada pelo reconhecimento jurídico universalmente assegurado e pela garantia das possiblidades de obter estima social pode ocupar lugar de um horizonte emancipatório como aquele imaginado por Horkheimer. Para explicar como as lutas que têm conscientemente orientado os movimentos sociais desde a emergência do capitalismo devem ser enquadradas em uma teoria do reconhecimento, Honneth precisa, pois, estabelecer uma ligação entre seu padrão avaliativo de uma evolução moral da sociedade e um conceito de justiça como horizonte organizativo da ação social.

Essa parece ser a tarefa proposta por Honneth em Sofrimento de Indeterminação, o autor volta à filosofia hegeliana, agora com intenções de reatualizar a "doutrina da eticidade" de Hegel presente na Filosofia do Direito. O procedimento segue de maneira "indireta", isto é, nem o conceito substancialista de Estado nem o de espírito são reabilitados. O núcleo da reatualização são os conceitos de "eticidade" e "espírito objetivo", o que deixa claro que é por meio desses conceitos que Honneth julga ser possível caracterizar essencialmente as esferas sociais hoje.

A atualização da "doutrina da eticidade" hegeliana preconiza uma reconstrução das relações modernas da vida, em um sentido normativo, quer dizer, ancorado nos padrões de interação necessários à efetivação bem sucedida da auto-realização individual. O conceito de eticidade é reatualizado como uma estrutura social em que a teoria da justiça tenha por função garantir as condições para auto-realização individual. Este aspecto é buscado por ele na teoria do direito de Hegel, para quem este deveria consistir na existência da vontade livre, isto é, na possibilidade de os indivíduos desfrutarem de respeito e segurança para realizarem suas potencialidades. Estas condições estariam estruturalmente contidas no horizonte normativo de uma ordem socialmente justa na qual os indivíduos pudessem realizar tanto sua liberdade quanto a interação com seus parceiros, de modo que, mantendo-se fiel àquela definição fundadora de uma formação intersubjetiva das capacidades humanas, Honneth passa a 
entender as relações comunicativas como um bem básico. Ao contrário da formulação de John Rawls, porém, os bens básicos não são objeto de uma distribuição justa e sim de uma garantia de acesso. Dessa forma, enquanto a teoria de Rawls poderia se colocar no campo das teorias corretivas, o objetivo da versão de Honneth para a teoria da justiça é fundamentação de padrões de relações sociais de reconhecimento. Assim, portanto, motivado pelo diagnóstico do "sofrimento de indeterminação" como patologia que resulta da realização incompleta ou insuficiente da vontade livre em âmbito institucional da sociedade moderna não estruturada conforme a eticidade, Honneth aponta pra uma definição de eticidade como questão de justiça. Para ele, a absolutização da liberdade moral e jurídica, ou seja, do "direito abstrato" e da "moralidade", constituem, segundo seu diagnóstico, patologias do mundo da vida social que somente as exigências das esferas de eticidade devem poder levar a uma libertação duradoura e denotar o caminho para a auto-realização individual de todos os indivíduos das sociedades modernas. Em tal esfera então se delineia uma teoria normativa da modernidade, crítica e preocupada com os pressupostos de uma vida social "justa" e boa.

Nesse sentido, a importância do conceito de "espírito objetivo", despido de sua essência metafísica, está no fato de ele conter a ideia de que a realidade social é constituída de fundamentos racionais que, uma vez violados, causam prejuízos à autorealização dos indivíduos. Esses fundamentos racionais são as próprias esferas e práticas sociais estruturadas pelo reconhecimento. Os direitos universais estabelecidos pertencem apenas mediatamente à esfera do indivíduo e primeiramente às relações e estruturas sociais, às formas de "existências" sociais necessárias para a realização da "vontade livre". Essa constatação abre a perspectiva de caracterização das esferas sociais como núcleo e fundamento das formalizações e institucionalizações societárias no pensamento de Honneth.

A partir dessa determinação do "social", é possível caracterizar teoricamente a modernidade através de uma "reconstrução das esferas sociais da modernidade" e não simplesmente por intermédio de uma reconstrução das instituições da modernidade. Assim, a teoria normativa da modernidade precisa mobilizar as estruturas e relações éticas da vida social, dito de outro modo, ela é capaz de lidar com o padrão de práticas intersubjetivas que permitem aos membros da sociedade a possibilidade da autorealização, na medida em que se relacionam uns com os outros, enquanto relacionamento moral baseado no reconhecimento recíproco. O caráter dessa teoria 
normativa da modernidade, como reconstrução das esferas sociais modernas, dá o tom da crítica anti-institucionalista que Honneht faz à teoria do Estado contida na Filosofia do Direito de Hegel. Tal crítica tem como alvo aquilo que Honneth chama de “superistitucionalização" das esferas da eticidade (família, sociedade civil e Estado)

Segundo Honneth, Hegel enfatiza equivocadamente o caráter institucional de cada esfera e perde de vista o potencial inerente às práticas e relações éticas de cada um desses âmbitos. Em oposição a necessidade hegeliana de insistir em uma institucionalização positivada juridicamente, Honneth defende uma noção de "instituição" derivada dos costumes e dos hábitos adquiridos culturalmente. Para Honneth, a centralização nas formas institucionalizadas de relação limita e diminui os aspectos que podem ser atribuídos às características da liberdade nas sociedades modernas. Para Honneth está superistituiconalização da doutrina hegeliana enfraquece o potencial do diagnóstico de época, assim como esconde as verdadeiras fontes da liberdade. Para Honneth, embora no capítulo da "eticidade" da Filosofia do Direito, Hegel tenha a intenção de examinar as estruturas normativas das sociedades modernas, para tentar averiguar as condições historicamente constituídas da liberdade individual, ele teria confundido essa tarefa com a pretensão de analisar as instituições as quais legitimam as formas "concretas" de organização, principalmente aquelas constituídas juridicamente.

Finalmente, a preocupação com relação à eticidade e à atualização do espírito objetivo- e igualmente com a crítica à superinsitucionalização das esferas ético-sociais, em Hegel- dá o tom da abordagem adotada por Honneth em Sofrimento de Indeterminação. Ele mantém o núcleo da sua teoria da justiça nas esferas sociais e na conceitualização do social, enquanto fonte materialista e conflituosa tanto das ações e movimentos sociais quanto dos processos de formalização e institucionalização das normas societárias.

O pensamento social de Honneth procura se contrapor à duplicidade das esferas racionais como "complexos institucionais", tal como propõe a teoria da ação comunicativa de Habermas. Como decorre de sua crítica à doutrina da eticidade, tanto o domínio da racionalidade sistêmica quanto o da comunicativa têm suas raízes nas esferas sociais de geração das ações e esse núcleo social não pode ser abstraído ou tomado secundariamente. Embora, as relações "enrijecidas" institucionalmente premeiem toda ordem social, o núcleo motivador e central dos desenvolvimentos e 
mudanças históricos encontram-se nas relações comunicativas entre grupos integrados social e culturalmente.

Honneth desloca para o centro da sua teoria as relações morais bem como as práticas e esferas ético-sociais. Com isso, ele procura não abstrair os fenômenos patológicos, "exportando-os" para complexos de razão. Assim ele não subestima o papel determinante dessas patologias na experiência vivida dos indivíduos. Da mesma forma, ele não negligencia o potencial de organização emancipatória contido nos movimentos e reivindicações por reconhecimento e dignidade. O conceito formal de eticidade e os modelos de liberdade comunicativa da teoria normativa da modernidade servem como critérios normativos para a avaliação dessas lutas sociais em referência ao seu caráter emancipatório ou reacionário.

A teoria do reconhecimento proposta por Honneth revela a sua preocupação em considerar a importância das esferas sociais em relação ao seu papel fundador de movimentos e reivindicações que visam a formas de emancipação e libertação do sofrimento e do desrespeito, nas sociedades capitalistas modernas. Esses fenômenos patológicos muitas vezes são encobertos por configurações demasiadamente institucionalistas, cujo funcionamento em muitos casos pode barrar a possibilidade de articulação e reivindicação coletivas por reconhecimento, dignidade e justiça.

O que a teoria normativa honnethiana positivamente pode enfatizar e indicar é a necessidade de maior "abertura" dos âmbitos institucionais para os movimentos coletivos que lidam e interpretam, em ampla medida, práticas sociais e institucionais como sendo desrespeitosas ao seu modo de vida. A preocupação com a formação da liberdade, com os processos de aprendizagem sociais e com o diagnóstico de patologias que afetam o mundo da vida seguramente fornece um contraponto, cuja positividade é indicar maior participação dos sujeitos sociais. Com isso é possível visualizar a ampliação da participação e o incentivo de certo protagonismo social, nos processos de construção e configuração da politica democrática. A teoria normativa honnethiana apresenta ainda a positividade de configurar como mais um modelo de teoria da modernidade que objetiva identificar potenciais emancipatórios das relações comunicativas. Ela não cede ao diagnostico pessimista que vê na modernidade o contínuo e exclusivo desenvolvimento de relações instrumentais ou sistêmicas.

Assim, é possível afirmar que o empreendimento honnethano tem por mérito e potencial revelar que os conflitos podem ser entendidos como conflitos morais e 
comunicativos, no plano do desenvolvimento das identidades coletivas e das sociedades. Ele revela os potenciais não explorados de uma teoria social crítica interessada nos conflitos e nas lutas sociais enquanto fundamentos sociocomunicativos da crítica, o que permite o desenvolvimento de uma nova Teoria Critica, como quer o próprio Honneth, a partir da reconstrução normativa das esferas sociais cotidianas.

Esperamos, enfim que o presente trabalho tenha contribuído para o esclarecimento e reflexão desta nova proposta crítica de Axel Honneth, assim como ter aberto perspectivas para o pensamento e análise das questões sociais e filosóficas prementes do contexto contemporâneo das nossas sociedades modernas. 


\section{REFERÊNCIAS}

ADORNO, Theodor W. e HORKHEIMER, Max. (1985). Dialética do Esclarecimento: fragmentos filosóficos. Rio de Janeiro: Jorge Zahar, Ed.2006.

ASSOUN, Paul-Laurent e RAULET, Gerard, Marxismo e teoria crítica, Zahar editores, Rio de Janeiro, 1981.

FOUCAULT, Michel, "Introdução" in Arqueologia do saber, Vozes, Petrópolis, 1972 ,Vigiar e Punir, Vozes, Petrópolis, 2007.

FRASER, Nancy and HONNETH, Axel, Redistribution or recognition. A politicalphilosophical exchange, verso, London-New York,2003.

HABERMAS, Jürgen. A inclusão do outro. Estudos de teoria política, Edições Loyola, São Paulo,2004. . Conhecimento e interesse. Rio de Janeiro: Zahar, 1982.

$\overline{\text { Edições }}$

.(s/d). Técnica e ciência como "Ideologia". Trad: Artur Morão, Lisboa:

Teoría de la acción comunicativa: crítica de la razón funcionalista.Madrid, Taurus Humanidades (Vol. II), 1992

Teoría de la acción comunicativa: racionalidad de la acción y

racionalización social. Madrid, Taurus Humanidades (Vol. I), 1999.

HEGEL, G. W. F. Introdução à filosofia do direito. Trad: Marcos Lutz Müller. Clássicos da Filosofia: Cadernos de tradução. Campinas, IFCH/UNICAMP,2005.

HONNETH, Axel e FRASER, Nancy. . Recognition or redistribution? A political-philosophical exchange. Londres/NY: Vers,2003.

HONNETH, Axel. "Integrity and disrespect" in The fragmented world of the social. Essays in social and political philosophy, State University of New York(SUNY) Press, Albany, 1995.

(2003). Luta por reconhecimento: a gramática moral dos conflitos sociais.Trad: Luiz Repa. São Paulo: Ed. 34.

(2007). Sofrimento de indeterminação: uma reatualização da Filosofia do Direito de Hegel. Trad: Rúrion Soares Melo. São Paulo: Editora Singular, Esfera Pública.

.(1991). The critique of power: reflective stages in a critical social theory. Trad: Kenneth Baynes - 1st MIT Press ed.

(1999b). "The social dynamics of disrespect: situating critical theory today". In: DEWS, Peter (Org.). Habermas: a critical reader. Blackwell Publishers, p. 320-337. . (2003c). "Patologias da liberdade individual. O diagnóstico hegeliano de época e o presente". Trad: Luiz Repa. In: Novos Estudos CEBRAP, n 66, Jul/2003, p. 77-90. 
. “Honneth esquadrinha „Déficit Sociológico “”. (Entrevista a Marcos Nobre e Luiz Repa). In: Folha de São Paulo, E7, 11/10/03.

(2008). Uma patologia social da razão: sobre o legado intelectual da Teoria

Crítica. In: RUSH, Fred. (Org.). Teoria Crítica. Aparecida, São Paulo: Idéias \& Letras.

HORKHEIMER, Max. "Teoria tradicional e Teoria Crítica” 1968a In: Benjamin,W;

Horkheimer,M; Adorno,T.W; Habermas, J. Obras escolhidas, São Paulo: Abril Cultural. (Os Pensadores, vol.XLVIII),1980.

Filosofia e Teoria Crítica, 1968b in : Benjamin,W;Horkheimer,M;

Adorno,T.W; Habermas, J. Obras escolhidas, São Paulo: Abril Cultural. (Os Pensadores, vol.XLVIII), 1980.

LIMA, Erick Calheiros de. "Resenha: Sofrimento de indeterminação". In: Cadernos de Filosofia Alemã, XI, São Paulo - SP, Jan-Jun, p. 127-140, 2008.

NOBRE, Marcos. (2003a). "Luta por reconhecimento: Axel Honneth e a Teoria Crítica”. In: HONNETH, A. Luta por reconhecimento: a gramática moral dos conflitos sociais. Trad: Luiz Repa. São Paulo: Ed. 34, p. 07-19.

(2004). A Teoria Crítica. Rio de Janeiro: Jorge Zahar Ed.

(2008). "Max Horkheimer: a Teoria Crítica entre o nazismo e o capitalismo tardio". In: NOBRE, M. (Org). Curso livre de Teoria Crítica. Campinas, SP: Papirus, p. $35-52$.

REPA, Luiz. (2006). "Os modelos críticos de Técnica e ciência como ideologia e Conhecimento e interesse - a crítica de Honneth a Habermas". In: Crítica, Londrina, v. $11, n^{\circ} 33$, p. 199-212.

WERLE, Denílson L. e MELO, Rúrion S. (2008). "Reconhecimento e justiça na teoria crítica da sociedade em Axel Honneth". In: NOBRE, M. (Org). Curso livre de Teoria Crítica. Campinas, SP: Papirus, p. 183-198.

"Teoria Crítica, teorias da justiça e a „reatualização" de Hegel”. In: HONNETH, A. Sofrimento de indeterminação: uma reatualização da Filosofia do Direito de Hegel. Trad: Rúrion Soares Melo. São Paulo: Editora Singular, Esfera Pública, 2007, págs. 07-44. 
